\title{
Is all PR good PR? \\ How the content of media exposure affects candidate popularity.
}

\begin{abstract}
Existing evidence shows that media exposure is associated with increased political popularity, but we know less about how the electoral effects of media coverage may vary with the content of the coverage. By collecting hundreds of thousands of media articles, which we then sort by content using automatic topic modelling, we build a unique dataset of political candidates, their popularity, and the quantity and type of media exposure that candidates receive. Analysing this dataset, we find that media attention is, indeed, an electoral asset. Further, and crucially, we find that voters reward politicians for politically relevant exposure, while non-political exposure is ignored, or even penalised. Consequently, this is good news for how democracies work; voters hold politicians accountable based on relevant information. The findings are of relevance to students of media, political behaviour, parties and political competition, as well as normative democratic theory.
\end{abstract}




\section{Introduction}

Extant studies show that the media may affect public opinion and electoral outcomes (e.g. Iyengar and Kinder 2010). Whether this is good or bad news for democracy depends on why media exposure affects candidate popularity. If voters simply elect people that they have seen on television or read about in the newspapers, political representation - descriptive as well as substantive - may suffer. Another worry is that voters elect people who figure in the media for non-political reasons, rather than politically competent politicians.

In this article, we gather a unique panel dataset on media exposure and candidate popularity. Exploiting recent advances in automatic text analysis, we collect hundreds of thousands of media articles, which we sort by content as well as connect to politicians who run for office.

We then use these data to answer two research questions. Firstly, are politicians rewarded for media exposure? Secondly, does it matter for their electoral fortunes why they are in the media? Our findings suggest a positive answer to both questions. Voters reward politicians for figuring in media articles with political content, while they disregard politicians featuring in apolitical articles. In some cases, voters even penalise politicians that figure in the media for non-political reasons. This is good news for democracy. Our findings thus suggest that candidates are elected on the basis of politically relevant criteria, and that voters are more competent than often assumed in the literature (e.g. Converse 1964, Achen and Bartels 2016).

In the next section, we discuss the pertinent literature and derive hypotheses about the relationship between media coverage and candidate popularity, before giving a short presentation of the case. We proceed by describing our data collection. In the penultimate section we present the analyses and results before we discuss implications of our findings.

\section{Media and electoral behaviour}

Iyengar (2016: ch. 8) distinguishes between different types of political media effects. One is agenda control, the process through which news coverage affects public concern (see also Cohen 1963). Relatedly, there is priming, where the media influences the weight that citizens assign to particular issues when deciding how to vote (see Ansolabehere et al. 1993). Third, there are framing effects. This refers to how the media highlights some aspects of an issue while ignoring 
others, or use different words and phrases to describe the same phenomenon, in a way that may affect how the audience perceive the story (see also Druckman 2001).

These media effects may explain how media coverage can affect the electoral fortunes of individual parties or candidates. For instance, if the media consistently frames immigration as a problem, and primes voters to care about it when voting, populist right candidates may become more popular.

However, these effects do not easily account for why more media attention is generally associated with more votes. A large amount of evidence from political science and media studies supports the notion that media exposure leads to increased political popularity. While one survey experiment conducted on the British national elections of 1997 found that visibility of the parties has no effect on party choice (Norris et al. 1999), this seems to be the exception. Thus, Semetko and Schönbach (1994) find that the mere visibility of political actors is of major importance for party evaluations. Oegema and Kleinnijenhuis (2000) find that party leaders who were more visible in the media got more votes in the Dutch national elections of 1998. Maddens et al. (2006) find that media exposure is more important for candidate popularity in Belgian national elections than campaign expenditure. Van Aelst et al. (2008) find that candidates who received more media attention got more preferential votes in the Belgian elections in 2003, and Hopmann et al. (2010) find a moderate effect of media visibility on party choice in Denmark. Kam and Zechmeister (2013) find that political actors that are often in the media are also more popular.

When it comes to the first research question then, studies in both psychology, political science and media studies allow us to derive our exposure quantity hypothesis: The more media exposure a candidate receives, the more votes (s)he gets.

But why? We know much less about what kind of media attention politicians are rewarded for. Agenda-setting, framing, and priming can hardly account for the general, positive effect of media attention, as these phenomena should also create negative effects of media attention for some candidates and parties. We suggest potential mechanisms related to learning, another of the media effects discussed by Iyengar (2016: 241-243). Citizens primarily meet the political world through the media, and this is where they obtain information about candidates (Hansen and Pedersen 2014: 308). It is close to obvious that access to information about candidates is vital if voters are to prefer one above the other. Candidates can send all kinds of cues through the media: Policy position, 
policy salience, values, personal character traits, and so on (Goren 2013: 201). Iyengar (2016: 285288) distinguishes between three levels of relevant candidate information. The most basic level is name recognition. The second level is knowledge about the candidates' competence, moral values, and trustworthiness. The final level concerns the candidates' positions on relevant political issues. Clearly, citizens may learn about all of these aspects of a candidate through the media, and they may in turn reward certain candidates based on the information. It is, however, crucial for democracy which level of information citizens act on. The content of media articles decide what information is available to voters, as we will get back to below. Our main point is that some types of media coverage allow more learning than others.

The literature on electoral behaviour has quite different views on what to expect from the voters. The classics often found the voters wanting, either through lack of motivation, reasoning skills, and political knowledge (e.g. Berelson et al. 1954; Campbell et al. 1960) or because they hardly can be said to have consistent preferences or beliefs to base their vote on in the first place (e.g. Converse 1964). Some scholars conclude that most people "know jaw-droppingly little about politics" (Luskin 2002: 282), or that voters are "depressingly far from having realistic perceptions of the political world" (Achen and Bartels 2016: 276). Studies have shown that voters are swayed by apolitical events such as shark attacks (Achen and Bartels 2016: ch. 5), or even sports events (Healy et al. 2010). Furthermore, experiments in psychology have found that even sublime recognition make voters more likely to vote for a candidate, predict that the candidate eventually will win, and associating the candidate with positive traits (Goldstein and Gigerenzer 2002; Kam and Zechmeister 2013; Weinberger and Westen 2008; Kunst-Wilson and Zajonc 1980; Zajonc 1968).

Based on all this, and given that all media coverage of a candidate will at least provide information on the candidate's name, we derive our name recognition hypothesis: The topic of the media coverage does not matter for candidate popularity; quantity is all that matters.

However, not all scholars agree that voters are incompetent. Revisionists such as Goren (2013) claim that voters are more consistent then we give them credit for, and others have made the case that they can act as if they have enough information, for instance through the use of cues (Popkin 1991; Sniderman et al. 1991; Page and Shapiro 1992; Lupia 2003). Goren (2013: 11) concludes that "fears about voter incompetence are overblown. Put simply, the typical American voter 
performs reasonably well". Other scholars have been unable to replicate the results indicating that voters are swayed by irrelevant events (Fowler and Hall 2017; Fowler and Montagnes 2015) and also conclude that "voters are more competent than previously thought" (Fowler and Montagnes 2015: 13803).

Furthermore, some kinds of media coverage provide more learning because they are politically relevant. We define "politically relevant" attention as media exposure that contains information on the two upper levels of candidate knowledge identified by Iyengar (2016): Competence, moral values, trustworthiness, and issue positions (see below for a further discussion of this). Thus, voters may learn about candidates' policy proposals, political values, competence, and so on.

We may expect competent voters to reward politicians who get political media exposure, from which they can derive policy proposals, political values or in other ways make competent choices. Based on this, we derive our competent voter hypothesis: Voters only reward politicians for politically relevant media attention.

These hypotheses matter not just for theories of media effects or voter competence. The name recognition hypothesis comes with some worrisome implications for democracy. First, it suggests that well-known people with less relevant experience may replace competent politicians. Second, it implies that voters do not hold politicians accountable or vote on the basis of media exposure from which they can derive relevant information about candidates' policy proposals, political values or competency. It thus implies a crisis of representation in democracies. Contrary to the name recognition hypothesis, the competent voter hypothesis implies that democracy is doing fine. Voters act on politically relevant information, and discard irrelevant information. Representation is secured and competent candidates are more likely to be elected.

We use unique data on politicians from three local elections in Oslo, the capital of Norway, to test our hypotheses about how candidates' media exposure affects the number of preferential votes they receive in elections, if at all. Exploiting recent advances in computational power and automatic text analysis, we are able to sort hundreds of thousands of media articles by topic and then see how the kind of media attention affects candidate popularity. We address the issue of causality through different designs, such as candidate fixed effects models, controlling for previous public notoriety, and so on (see below for details). In the next section, we describe the municipal elections of Oslo 
more closely, and discuss the merits of studying this strategically selected case. We then describe the data and methodology, before presenting the results.

\section{Case: Municipality elections in Oslo, Norway}

Municipality elections in Oslo follow a party list proportional representation system (for detailed description of the election rules, see Lovdata.no 2018). The parties order the candidates on their lists, and voters influence this ordering by giving preferential votes (Bergh et al. 2010). Each voter's ballot is multiplied with the total number of mandates in the municipality. As the Oslo municipal council has 59 seats, this means that each voter has 59 votes. Voters can choose to give a preferential vote to candidates not on the list they are voting for. In practice, this transfers one of the 59 votes to this list instead, up to a maximum of 14 such "swing-votes", as they are often called. All parties cumulate a number of candidates on their list, up to a maximum of ten. In practice, it is impossible for a non-cumulated candidate to get the spot of a cumulated candidate. However, voters can influence the ranking among cumulated candidates, and the ranking among noncumulated candidates. Each list can thus be split into two competitions. Within each of these two competitions, the final ranking is ordered by each candidate's sum of preferential- and swing votes.

To sum up, voters choose a party list with a suggested order of candidates. They may give preferential votes to candidates they like in particular from the party they voted for or give swing votes to candidates they like from other parties. This allows us to measure candidates' individual popularity in an otherwise heavily party-centred electoral system.

\section{Local election in a party-centred system: A strategically selected case}

We want to test our hypotheses in a way that makes the conclusions relevant beyond the case we study. We would argue that an ideal case is one where voters have few incentives and possibilities to gather and act on information about individual candidates. This could for instance be elections of low salience, or elections in party-centred systems. If voters are able to distinguish between politically relevant and irrelevant media coverage of individual candidates - and act on this information - even when there are few incentives and possibilities to do so, surely we would expect the voters to also be able to do so in elections with higher salience or more focus on candidates rather than parties. In the following, we argue that our case is close to such an ideal case, for two 
reasons: The lower salience of local elections compared to most national elections, and the PRbased and party-centred electoral system of Norway.

Goren (2013: 201) claims that there are three sources for information about political candidates' policy positions. The first is directly from the campaign and its media coverage, which supplies an "ongoing stream of redundant cues about candidate stances" (ibid.: 201, see also Eberl et al. 2017: 1126). However, the local elections of Oslo are not covered to anywhere near the same extent as, say, presidential elections in the US. Also, there are an enormous number of candidates (an average of 707 candidates per election) relative to the few who are usually running in presidential elections or in majoritarian electoral systems in general.

Second, there is party-based inference - voters can deduce the policy positions of the candidates based on their party membership (Conover and Feldman 1989). This is perhaps the most potent source of general information about candidates' political positions, especially in party-centred systems. However, in the local elections in Oslo, we study the preferential votes given to candidates running for the same party as the voter voted for. In other words, these are intra-party competitions - so party cues are much less prominent, if they exist at all.

Finally, Goren (2013: 202) mentions that voters also receive information about the candidates' position through their social networks and when engaging in non-political activities (Huckfeldt and Sprague 1995). This is also true for Oslo local elections, but the degree to which candidates' policy positions figures in conversations or, say, humour programs, is related to the salience of the elections - which, as mentioned, is lower for local elections. Furthermore, the electoral system in the Norwegian local elections is PR-based and heavily party-centred. Regardless of salience, interested voters primarily have incentives to seek out information about the parties' positions, not the candidates'. In Norway, voters primarily vote for parties, not candidates. Norwegian parties are extremely cohesive and disciplined, and function as unitary actors to a very large degree (Rasch 1999).

If a candidate makes a statement, it is thus generally perceived as the position of the party, unless the candidate explicitly makes the point that he or she disagrees with the party. The many candidates, lower salience and media coverage, absence of party cues, and few incentives to get information on candidates, make sure that the odds are heavily stacked against finding any importance of individual candidates' media exposure. If we find that voters are indeed able to 
distinguish between relevant and irrelevant media content in the Oslo local elections, and act upon this information, then there are good reasons to expect this to be the case in more salient elections with fewer candidates as well (e.g. various national elections). Furthermore, if we find that voters are able to do this in a party-centred system with few incentives to seek out information about individual candidates, then surely we would expect to find voters able to do so in more candidatecentred systems such as the British or American political systems. The case is thus not chosen because it is representative of elections elsewhere, but as a critical case whose conclusions are likely to be generalisable.

We highlight that there is a wide variety of types of media coverage among individuals seeking office in Oslo, along with all the less well-known candidates. Among the candidates, we find individuals such as Knut Nærum, an intellectual comedian and socialist that appeared on television every Friday for 16 years, on the most popular TV-show in Norway (an average viewer rating of about one million in a country with five million people). We find the philosopher Arne Næss, who is widely known in the Norwegian public. It includes Lars-Lillo Stenberg, the front man of the DeLillos, one of Norway's most famous rock bands, and Erlend Loe, among Norway's most famous authors and on the curriculum in primary school. These individuals mostly get nonpolitical media coverage. But the lists are also populated by well-known political individuals, such as Carl I. Hagen, the eccentric leader of Norway's right-wing Progress Party for almost 30 years, building what is today Norway's third largest party. Or Thorvald Stoltenberg, a Norwegian diplomat and foreign minister, central in the peace negotiations during the Balkan wars, whose son, Jens Stoltenberg, is secretary general of NATO and served as prime minister of Norway for a total of nine years. Finally, Geir Lippestad, the lawyer of the 22. July terrorist, who after the trial entered politics for the Norwegian Labour party.

In other words, the candidates for the local elections demonstrate a great variation when it comes to both the extent and the type of media coverage they receive, and this allows us to infer about the relative importance of different kinds of media exposure.

In what follows, we will first elaborate on the methodology used. We will then demonstrate empirically that voters, even in this very hard test, demonstrate a high level of competence: Politicians are rewarded only for figuring in media articles with political content, while apolitical media attention is ignored or even penalised in the voting booth. 


\section{Data and Methodology}

We have gathered data on all candidates from all parties in the 2007, 2011, and 2015 municipality elections in the Norwegian capital, Oslo. These data are collected from three separate sources. First, the main data consists of structured election protocols from all four elections, listing candidates, ranking, party, preferential votes, and more. These data are available from the official municipality website in raw form (Oslo Kommune 2018). Second, Statistics Norway provided data on age, country of origin, income, and the education levels of the candidates. These data are only available from 2007, which is why our analysis does not contain elections further back in time.

Finally, and most crucially, we used the names of the candidates to scrape all newspaper articles in which they were mentioned through the API of Retriever (Retriever Norge 2018). This amounts to a data frame with several hundred thousand newspaper articles. Using automated topic models, we estimate the topic of these different articles. It is important to note that Norway has an extremely high use of newspapers. More than $80 \%$ of Norwegians older than twelve years read newspapers daily (Aftenposten 2018), and newspapers (along with conversations with others) constitute the most important source of information about candidates in local elections (Karlsen 2017). Using newspaper coverage, rather than for instance television coverage, is then the most suitable strategy in our case. After aggregation, our data frame consists of 2,122 candidates. Descriptive statistics for the variables used in the main analyses can be found in the appendix.

\section{Preferential votes}

Our dependent variable is the amount of preferential votes a candidate received at the relevant election, from the voters of that candidate's party. We do not include swing votes, as these not only tap into intra-party but also inter-party competition. However, we have run specifications including swing-votes to see if it changes our findings. If anything, these results strengthen our conclusions. We always use the natural logarithm of preferential votes to account for its exponential relationship with media coverage. ${ }^{1}$

As shown in figure 1, there has been a flattening in the density of preferential votes over time; there were more candidates receiving between 0 and 50 preferential votes in the 2007 elections. In

\footnotetext{
${ }^{1}$ Since some candidates do not get preferential votes, and it is impossible to take the natural logarithm of 0 , we use $\ln ($ preferential votes +1$)$.
} 
the 2011 and 2015 elections, however, substantially more candidates received between 50 and 150 preferential votes. In the 2015 election, no candidates got zero preferential votes. This could indicate that the voters have gone through a learning process after the current election rules were implemented before the 2003 election. It could also be an effect of the media producing more content, and the overall media exposure of candidates - even at the local election - exploding as web-based news outlets have become more important.

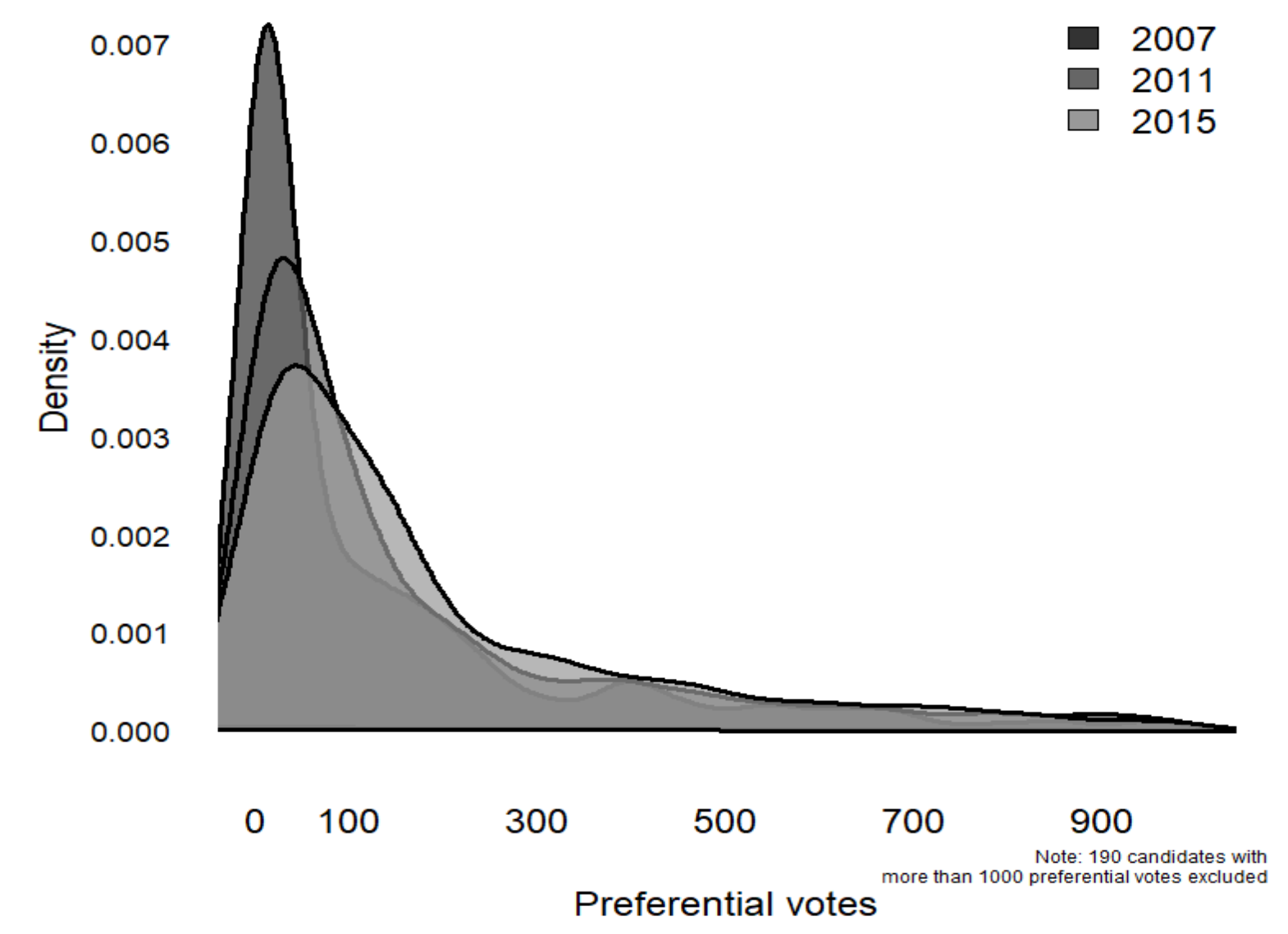

Figure 1: Kernel density plot of preferential votes 


\section{Topics}

To identify clusters of topics among our newspaper articles, we estimate a Latent Dirichlet Allocation (LDA) model through the stm-package for R (Roberts et al. 208). Topic models have several preferable attributes which make them useful for this analysis. First, the process is automated. Due to the vast amount of articles, a manual approach would be impossible. Second, topic models are probabilistic, which assumes that a given document (in our case newspaper article) can exhibit multiple topics (Bleu 2012: 78). For example, an article can contain words associated with both education and finance. The model estimates the probability that each document (article) belongs to all topics; each article's load over all topics sums to 1. When counting the number of articles within different topics, we therefore use this probability-estimate as a measure of proportion.

Two important assumptions of our modelling of topics are worth mentioning: First, the number of topics is both assumed to be known and fixed. We forced the procedure to yield 25 topics. Decreasing the number of topics implies increasing the abstraction of the topics. The number of topics is therefore a trade-off between overall parsimony and distinguished substance between topics. Too many topics yields narrow substance, decreasing the comparability between candidates' media exposure. In this trade-off, we landed on 25 (Blei 2012: 83). Second, and somewhat more problematic in our application, the model assumes that document order does not matter. The reason for this being problematic is that topics might change over time. We account for this by adding time as a covariate in the STM estimation. We also slightly loosen the bag-ofwords assumption by including bigrams and trigrams. While some argue that bag-of-words is a harmless assumption (Blei 2012: 82), more recent analyses indicate that word order can have impact on the automated procedures (Søyland and Lapponi 2017). Instead of using only one-word (unigram) term frequencies, our model includes bigrams and trigrams. More plainly, this means that we allow word order to matter in the classification. In addition to the above-mentioned specifications, we also remove stop-words and numbers, use only the stem of the words, and convert all characters to lower-case.

While LDA identifies clusters of words, it does not say anything about the substantial contents of those clusters. Scholars must identify the content of the different topics. Independent of each other, the three authors a) inspected the ten words that were most frequent in each topic; b) inspected the 
ten words that were most exclusive for that topic; c) read twenty of the most exclusive articles within each topic; and d) read twenty random articles with a high load within each topic.

Comparing notes, it proved relatively easy to identify the topic of each cluster. At first sight, the most problematic topic was the one we have labelled "Health and technology". The topic is mainly populated by articles on health politics, but there are also some unrelated articles on the latest smartphones or technological innovations. Although we can only provide anecdotal evidence, we believe these articles have been clustered together because the health sector in Norway was going through a reform to update the technological capacity. Many of the phrases in articles about this reform are therefore shared with articles on technology in general.

Of the 25 topics, we throw out six. Five of these were noise, generated from words without meaning: English words, programs from cultural events, programs from other types of events, lists of sport results, and ads. One topic included news about accidents, such as car-crashes. One topic consists of lists of exchanges of property, which is common to print in some local newspapers. Below, we discuss the content of, and the political information available in, articles from the remaining 19 topics. As mentioned above, we consider topics that provide information on the two upper levels of candidate knowledge as identified by Iyengar (2016) as politically relevant: Competence, moral values, trustworthiness, and at the very highest level, issue positions. Topics that are unlikely to contain much such information are not considered politically relevant.

First, Business includes articles on some of the major businesses in Norway, and their investments and fusions, while Court cases are articles filled with words from the courtroom, such as lawyer, prosecutor, and judge. Unlike the American context, having a background from business or law is neither considered particularly meritable (nor unmeritable) for Norwegian politicians. On our reading, there is little politically relevant information in these articles. Cultural events are mainly reviews of cultural events where politicians are present, with very little, if any, political information. Economic analyses include articles analysing, commenting, or reporting on macroeconomics. Being an economist does provide cues about competence and trustworthiness in the Norwegian context. For instance, the former Prime Minister Jens Stoltenberg's background as an economist was frequently capitalised on during his handling of the financial crisis. Furthermore, some of these articles include political discussions of the state of the economy, which is well known to be relevant to voters (e.g., Lewis-Beck and Costa Lobo 2017). Education consists of 
articles about education and the school system, a clearly political topic. The topic Emergencies is mainly populated by emergency incidents, like fire, drowning, avalanches, but also animal crime (torture of cats, shooting of protected wolves etc.). Some of these include reactions from different interest groups and politicians. In some cases, these articles include politicians being held accountable for emergencies, or questions about how they will handle them or prevent them in the future. Energy policies includes articles on emissions, sustainable economy, oil, and energy, and is clearly a political category. Football concerns football, the most popular sport in Norway, with no political information. Health and technology is mentioned above. It is mainly about health politics, but contains some articles on technological innovations. Many of the articles are thus politically relevant. Immigration concerns immigration and integration on both the national and local level, and is politically relevant. Intellectual includes texts on ethics, morality, social science, and humanities. Most of these come from magazines and newspapers often read by highly educated and politically interested people, such as Morgenbladet. They contain information about politicians' moral values, trustworthiness, competence, and, in some instances, also issue positions. Infrastructure mainly concerns transportation infrastructure: Roads, railroads and road tolls, a salient political topic in Norway. National politics is about meta-politics, with articles about polls, potential coalition partners, and political analyses. New Norwegian is one of Norway's official languages. This topic concerns different issues but are united by being written in New Norwegian. While we considered leaving this out, the issue of how big a role New Norwegian should play in the Norwegian education system is an important question to parts of the population. Furthermore, a politician writing in New Norwegian is certainly indicating trustworthiness to those using this language. A politician writing op-eds in New Norwegian may thus attract votes from people who support the use of this language. As such, we decided to keep this category in the analyses. Portfolio negotiations contains words of politicians' titles, such as minister, member of parliament, and so on. The topic typically includes articles on national or local reshuffles. Profile features are exactly that. They are usually interviews of individual candidates, in their home or in some environment they are comfortable in. It is quite clear that Norwegian politicians use profile features to signal their virtues, moral values, and trustworthiness. Urban planning is the only topic that seems to solely concern the local politics of Oslo, and is highly politically relevant to the population in the capital. The topic includes major public investments in Oslo, such as roads, sports arenas, art museums, etc. Urban-Rural taps into one of 
Norway's long standing political cleavages. It concerns articles on issues such as the price of food and animal welfare, including accept of fur farms and the shooting of Norwegian wolves, which typically divides Norway between urban and rural areas. July 22 are articles that concern the July 22 terrorist attacks and their aftermath. While the parties and politicians mostly agreed not to politicise this issue, it is clear that politicians were sometimes signalling their moral values when discussing the topic. We summarise the information contained in the different topics in the appendix, see Table A.2.

In order to move from the LDA-results into variables, each of the articles mentioning a certain candidate are summed together, grouped by topic. However, before the articles are summed together, they are also depreciated by the time between the article was published and election day. The depreciation factor determines by how much the weight of an article is reduced with time. This is done to take into account that media exposure is likely to be more valuable the closer it is to election day. We have tested different depreciation factors. The most punishing depreciation factor (0.7) indicates that an article is only weighted as 0.7 articles after a month. After a year, an article is basically worthless - it is weighted close to zero. With the least punishing depreciation factor (0.925), an article will survive four years before its value is approximately zero. In the models, we use the natural logarithm of these sums +1 (since several candidates have 0 hits within topics).

\section{Causality issues}

The rest of our data comes from two sources: Publicly available data on the elections, and background information on candidates from "Statistics Norway" (SSB). Descriptive statistics are available in table A.1. We introduce a number of control variables to reduce the risk of confounding.

Firstly, we add a dummy variable for whether or not the candidate participated in the previous election, and another dummy for whether or not the candidate was elected in the previous election - an incumbent-variable. Having participated in previous elections implies increased experience with election campaigns, including how to get media attention. As shown by Fiva and Røhr (2018), being elected has a causal impact on future preferential votes in Norwegian municipalities. We thus include previous participation as well as incumbency as control variables. 
We control for the distance to the last cumulated positions. For a party with ten cumulated candidates, the value on this variable is 1 for the $11^{\text {th }}$ candidate, and then increases for each rank up from 11. We emphasise that list position is the party's strongest signal about their own evaluation of candidates. Controlling for list position is thus likely to reduce confounding issues as it takes into account several qualities of the candidate.

We also add a dummy for candidates on the last nominated rank. It is typical for parties to put well-known individuals on this spot, in order to attract swing-votes. The idea is that voters check the first people on the list, but then get bored and skip a few pages, before taking a quick glance at the last name. By having an easily recognised name on this last spot, parties can attract some extra swing votes.

In the analyses, we exclude cumulated candidates, since, as noted above, the competition is different for the cumulated candidates and the non-cumulated candidates. All models include fixed effects for party and the election. Larger parties attract more attention, giving candidates from these parties systematically higher values on both media exposure and preferential votes, biasing our estimate. We also find it plausible that party membership correlates with the types of topics a candidate appears in. If so, our estimates would simply reflect that the topics of the larger parties are more popular. Party fixed effects removes any such concern. The same goes for election years. As shown above, there are more preferential votes given in later elections. There is also an increase in the number of articles being printed. If certain topics were more popular in earlier periods than later periods and vice versa, then our estimate would simply reflect that certain topics are more common in later years. Fixed effects on the election year removes any such concern. As an alternative specification, we also employ a multilevel model where candidates are nested within parties and elections, presented in table A.5 in the online appendix. This does not change the results.

To further ensure that there is no endogeneity at play, we employ three different empirical strategies: We control for previous public notoriety in two different ways, and we use fixed effects on each individual candidate, allowing each candidate to essentially be its own control. All these procedures yield the same results (see the robustness section below as well as the online appendix). Another potential problem is media bias (see, e.g., D’Alessio and Allen 2000, Hacket 1984, Hopman et al. 2011, Reeves 1997). Eberl et al. (2017) claim that there are three different sub-types 
of media bias: Visibility bias, tonality bias, and agenda bias. The first concerns the salience of parties or candidates in the news, the second how these are evaluated, and the third which issues they are able to address in media coverage. In other words, some parties - and by extension, their candidates - may be covered more often, more positively, and on issues of their own liking, compared to other parties. Fortunately, this problem is solved in our analyses as we only regard intra-party competition and introduce fixed effects for the parties.

The problem remains, however, if individual candidates within parties are systematically treated differently by the media in terms of visibility, tonality, or agenda. We know that social background factors such as gender (see, e.g., van Aelst et al. 2008: 203-204) may affect a candidate's media attention. We thus introduce controls for the candidates' sex, age (a 5-point scale), and world region of origin, in addition to the other controls: In our models, then, the estimates of the effects of media exposure on candidate popularity cannot be biased by incumbency status, previous election experience, list position, previous public notoriety, or the candidate's sex, age, or ethnicity. However, not only the candidates, but also the media outlets may have different characteristics. This does not affect the results, which are the same even when we re-run the models after excluding the outlets one by one. For more details on these analyses, see the appendix A.4.

\section{Analysis}

We present two analyses to test our hypotheses. First, we regress $\ln ($ preferential votes +1 ) on our main independent variable, $\ln ($ number of newspaper articles +1$)$, and the rest of the covariates described above. Second, we regress $\ln$ (preferential votes +1 ) on the number of newspaper articles within each different topic, using $\ln ($ topic +1$)$, and including the covariates above. In our main specifications, we use 0.975 as our depreciation rate of the articles, but we also show results using 0.7 as depreciation rate. We use OLS in all specifications. Cumulated candidates are removed from all models, and we always employ robust standard errors.

We present the results in table 1. To ease interpretation, we also provide dot-whiskers plots in figure 2 (Model 1) and figure 3 (Model 2).

Model 1 shows support for our straight-forward exposure quantity hypothesis: Politicians that appear more in the media, attract more preferential votes. Since we use the natural logarithm of both dependent and independent variable, a $1 \%$ increase in the number of (depreciated) articles in 
which a politician is mentioned, is expected to give about $0.16 \%$ increase in the number of preferential votes. The median candidate is mentioned in about three articles, and one extra mention can increase the number of preferential votes by $5-6 \%$.

To get a grasp of the importance of this effect, compare it to being ranked one position lower on the list, arguably the party's main signal of how they value the candidate. This yields an expected reduction in the number of preferential votes of about $3 \%$. Media exposure is thus important.

Moving to Model 2, it is clear that popularity in itself hides a more nuanced pattern of how voters respond to media attention. Specifically, candidates that are associated with political topics increase their preferential votes, many topics do not seem to matter much, and some can reduce the number of preferential votes. 


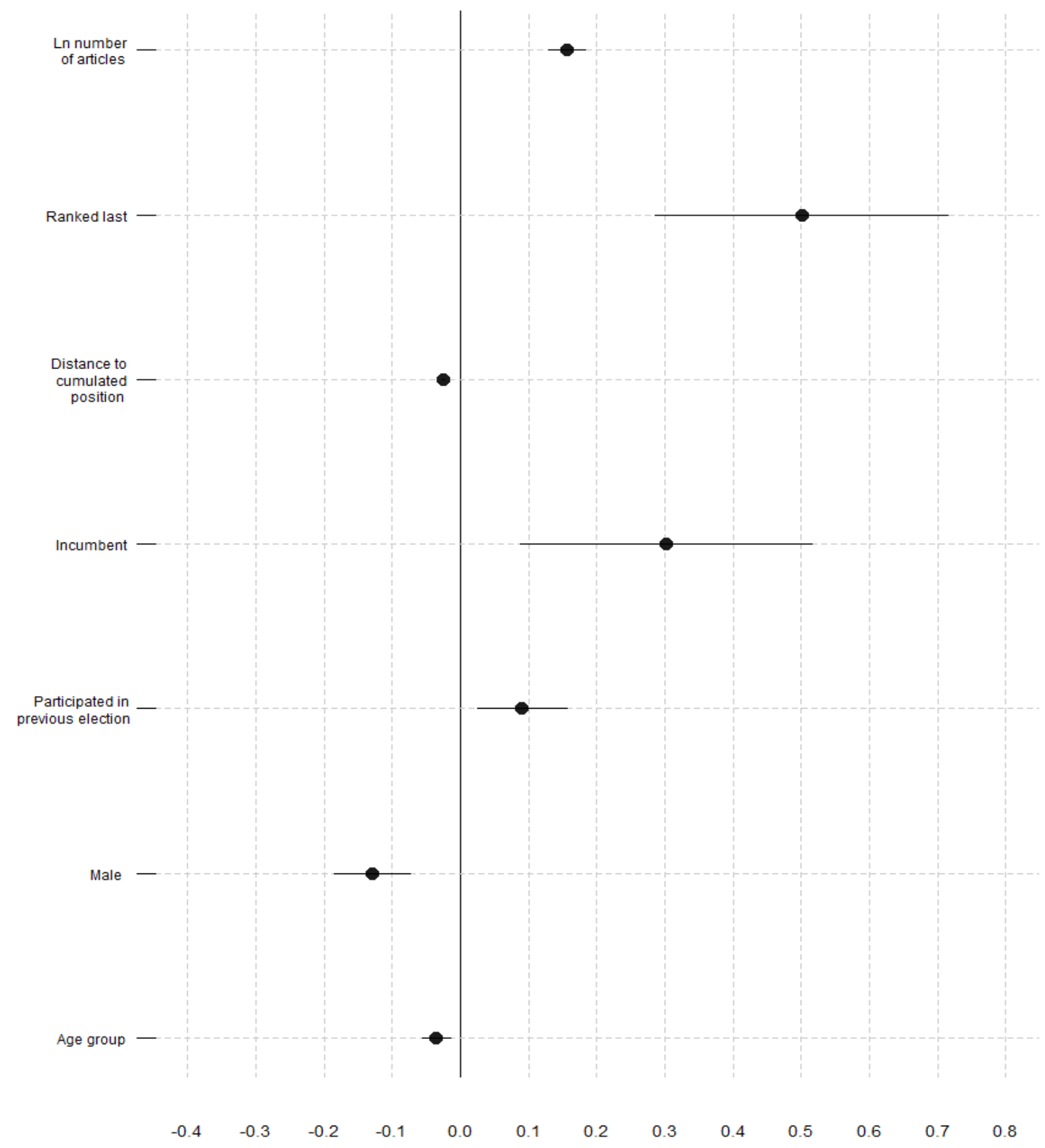

Figure 2. Dot-whisker plot of Model 1 from table 1. Point-estimates are indicated by the dots, and $95 \%$ confidence intervals by the horizontal lines 
We first note that the name recognition hypothesis fails to receive any support: Quantity is not all that matters. Media exposure within some topics yield more votes, some yield less, and some make no difference. The five topics that have a statistically significant positive effects $(\mathrm{p}<.05)$, are "Intellectual", "National politics", "Profile features", "Urban-rural", and "Urban planning". All of these clearly contain politically relevant information, as discussed above. The latter two are directly policy-relevant for citizens of Oslo, containing the highest level of candidate information, i.e. issue positions. The first three contain at least the second highest level of information. "Intellectual" articles can promote new ideas and signal values and competence through debates on ethics. "Profile features" are arguably less political, but such interviews are usually used strategically by the politicians to signal their political values and trustworthiness. "National politics" implies that the candidate is mentioned in relation to polls, commentaries, and other "meta-political" news at both local and national level, signalling that these are both capable and important individuals for the party.

Three other topics have positive effects, although these are only borderline significant. These are "New Norwegian", "22 nd July", and "Immigration", all of which were considered to contain politically relevant information.

On the other end of the scale, we find statistically significant negative effects for the topics "Emergencies" and "Football". The first of these two can be politically relevant, but are usually associated with negative coverage, e.g. a politician being held responsible for some aspect of the emergency. Coverage of football, a purely popular culture topic, is negative for the candidates. While this could indicate that voters avoid candidates that do not show interest for politics, we highlight that "Cultural reviews", also a purely "popular culture"-type of topic, has no systematic effect on preferential votes. A more reasonable interpretation is that different types of popular attention have different effects on how voters perceive the political capability of the candidate.

Using instead a depreciation factor of 0.7 , this pattern seems to be strengthened. The significant coefficients all increase in strength in their respective directions. For the non-significant coefficients, some move towards zero, some away from zero, but they all become more uncertain. 


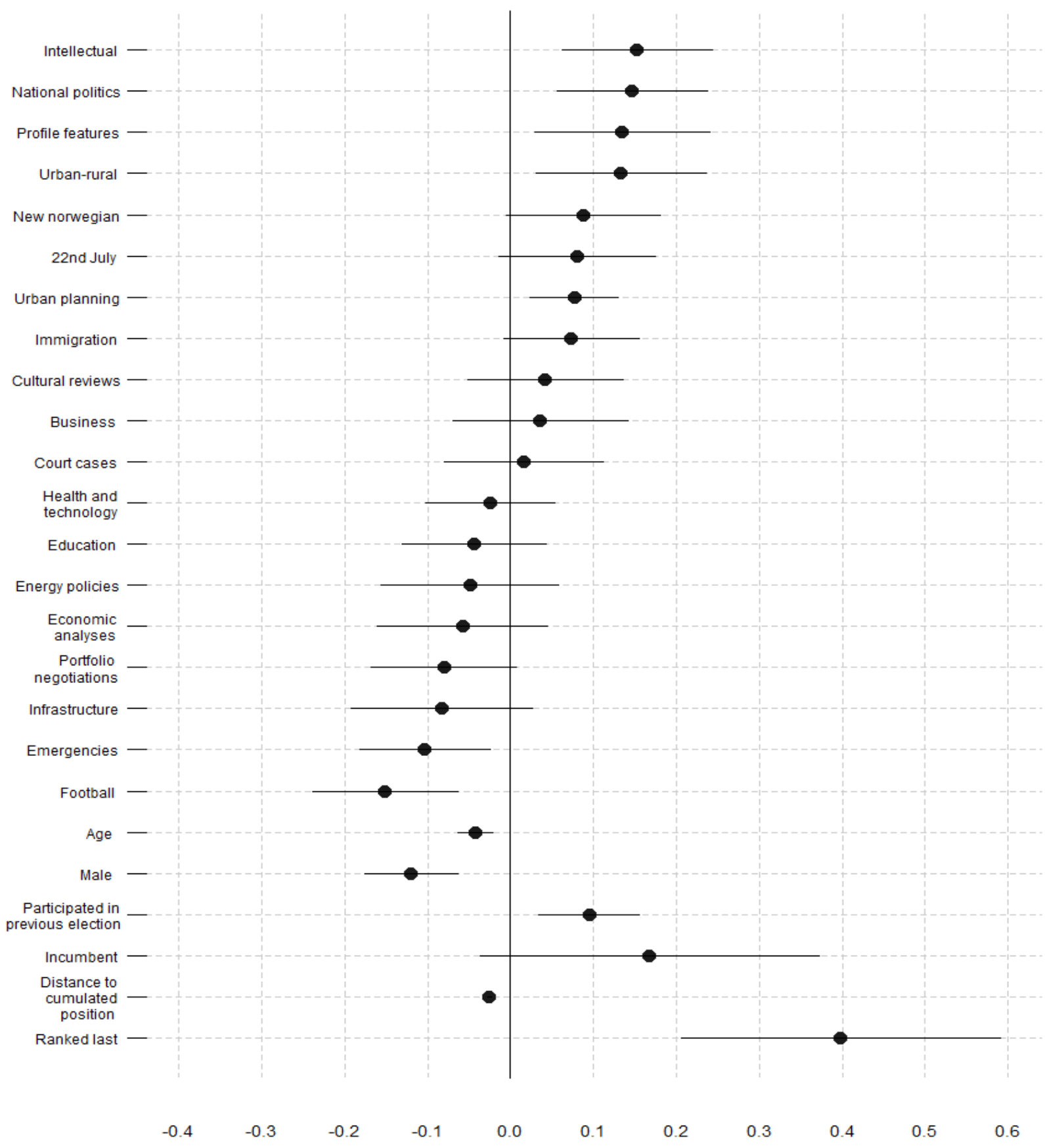

Figure 3. Dot-whisker plot of Model 2 from table 1. Point-estimates are indicated by the dots, and $95 \%$ confidence intervals by the horizontal lines 
The rest of the covariates are all as expected based on previous research, and are consistent across models. Being ranked last increases the expected number of preferential votes by $50 \%$, although it should be taken into account that these candidates are always far from a cumulated position, which decreases their expected number of preferential votes. ${ }^{2}$ Incumbents generally tend to get more preferential votes, but this coefficient is estimated with much uncertainty, and is borderline insignificant in models 2 and 3.

Candidates that participated in the previous election are expected to attract $9 \%$ more preferential votes, while women attract, on average, $12 \%$ more preferential votes than men. Finally, voters seem to prefer younger candidates, on average.

Table 1: Linear models on preferential votes

\begin{tabular}{|c|c|c|c|}
\hline & \multicolumn{3}{|c|}{ OLS } \\
\hline & Model 1 & Model 2 & Model 3 \\
\hline \multirow[t]{2}{*}{ Ln number of articles } & $0.16^{* * * *}$ & & \\
\hline & $(0.01)$ & & \\
\hline \multirow[t]{2}{*}{ Ln National politics } & & $0.15^{* *}$ & $0.22^{* *}$ \\
\hline & & $(0.05)$ & $(0.08)$ \\
\hline \multirow[t]{2}{*}{ Ln Intellectual } & & $0.15^{* * *}$ & $0.27^{* * *}$ \\
\hline & & $(0.05)$ & $(0.08)$ \\
\hline \multirow[t]{2}{*}{ Ln Profile features } & & $0.13^{*}$ & $0.23^{* *}$ \\
\hline & & $(0.05)$ & $(0.09)$ \\
\hline \multirow[t]{2}{*}{ Ln Urban-rural } & & $0.13^{*}$ & $0.25^{* *}$ \\
\hline & & $(0.05)$ & $(0.09)$ \\
\hline \multirow[t]{2}{*}{ Ln 22nd July } & & 0.08 & -0.01 \\
\hline & & $(0.05)$ & $(0.07)$ \\
\hline Ln New Norwegian & & 0.09 & 0.02 \\
\hline
\end{tabular}

\footnotetext{
${ }^{2}$ The effect of ranked position is non-linear, but we opted to keep the model simpler as our coefficients of interest does not change by adding polynomials to this variable.
} 


\begin{tabular}{|c|c|c|c|}
\hline & & $(0.05)$ & $(0.09)$ \\
\hline \multirow[t]{2}{*}{ Ln Immigration } & & 0.07 & 0.13 \\
\hline & & $(0.04)$ & $(0.07)$ \\
\hline \multirow[t]{2}{*}{ Ln Urban planning } & & $0.08^{* *}$ & $0.12^{* *}$ \\
\hline & & $(0.03)$ & $(0.04)$ \\
\hline \multirow[t]{2}{*}{ Ln Business } & & 0.04 & 0.02 \\
\hline & & $(0.05)$ & $(0.12)$ \\
\hline \multirow[t]{2}{*}{ Ln Cultural reviews } & & 0.04 & 0.09 \\
\hline & & $(0.05)$ & $(0.08)$ \\
\hline \multirow[t]{2}{*}{ Ln Court cases } & & 0.02 & 0.04 \\
\hline & & $(0.05)$ & $(0.09)$ \\
\hline \multirow[t]{2}{*}{ Ln Health and technology } & & -0.02 & -0.05 \\
\hline & & $(0.04)$ & $(0.06)$ \\
\hline \multirow[t]{2}{*}{ Ln Education } & & -0.04 & -0.10 \\
\hline & & $(0.04)$ & $(0.08)$ \\
\hline \multirow[t]{2}{*}{ Ln Energy policies } & & -0.05 & -0.02 \\
\hline & & $(0.05)$ & $(0.11)$ \\
\hline \multirow[t]{2}{*}{ Ln Economic analyses } & & -0.06 & -0.07 \\
\hline & & $(0.05)$ & $(0.10)$ \\
\hline \multirow[t]{2}{*}{ Ln Portfolio negotiations } & & -0.08 & -0.11 \\
\hline & & $(0.04)$ & $(0.10)$ \\
\hline \multirow[t]{2}{*}{ Ln Infrastructure } & & -0.08 & -0.06 \\
\hline & & $(0.06)$ & $(0.11)$ \\
\hline \multirow[t]{2}{*}{ Ln Emergencies } & & $-0.10^{* *}$ & $-0.19^{* *}$ \\
\hline & & $(0.04)$ & $(0.07)$ \\
\hline \multirow[t]{2}{*}{ Ln Football } & & $-0.15^{* * *}$ & $-0.26^{* * *}$ \\
\hline & & $(0.04)$ & $(0.08)$ \\
\hline \multirow[t]{2}{*}{ Ranked last } & $0.50^{* * *}$ & $0.40^{* * * *}$ & $0.41^{* * *}$ \\
\hline & $(0.11)$ & $(0.10)$ & $(0.10)$ \\
\hline Distance to cumulated position & $-0.03^{* * *}$ & $-0.03^{* * *}$ & $-0.03^{* * *}$ \\
\hline
\end{tabular}


$(0.001) \quad(0.001)$

$(0.001)$

\begin{tabular}{lccc} 
Incumbent & $0.30^{* *}$ & 0.17 & 0.20 \\
& $(0.11)$ & $(0.10)$ & $(0.11)$ \\
Participated in previous election & $0.09^{* *}$ & $0.09^{* * *}$ & $0.09^{* *}$ \\
Male & $(0.03)$ & $(0.03)$ & $(0.03)$ \\
& $-0.13^{* * *}$ & $-0.12^{* * *}$ & $-0.11^{* * * *}$ \\
Age & $(0.03)$ & $(0.03)$ & $(0.03)$ \\
& $-0.04^{* * *}$ & $-0.04^{* * *}$ & $-0.04^{* * *}$ \\
Constant & $(0.01)$ & $(0.01)$ & $(0.01)$ \\
& $6.72^{* * *}$ & $6.79^{* * *}$ & $6.89^{* * *}$ \\
\hline Election Year FE & $(0.07)$ & $(0.06)$ & $(0.06)$ \\
Party FE & Yes & Yes & Yes \\
Region of origin FE & Yes & Yes & Yes \\
\hline Article depreciation: & Yes & Yes & Yes \\
Observations & $0.925(4$ years $)$ & $0.925(4$ years $)$ & $0.7(1$ year $)$ \\
$\mathbf{R}^{2}$ & 1,900 & 1,900 & 1,900 \\
\hline Note: & 0.89 & 0.90 & 0.90 \\
& & $*$ & p $<0.05 ;{ }^{* *} \mathrm{p}<0.01 ;{ }^{* * *} \mathrm{p}<0.001$ \\
& & Robust standard errors in parentheses
\end{tabular}

\section{Robustness tests: Dealing with endogeneity}

As discussed above, it may well be that there is some form of endogeneity at play. One particular problem is that a candidate may be highly popular or well-known already before 2007. This popularity may well both cause the candidate to receive more media attention in the 2007 (or 2011 and 2015) election(s), and to receive more votes. In that case, our estimates will be biased upwards. To make sure this is not a problem, we re-estimate our analyses with control for previous public notoriety. We run one set of models where we control for each candidate's number of articles in each topic in 2003. Thus, we control for whether the individual was already in the spotlight prior to the 2007 election. We also follow a similar procedure, but control for each candidate's number of articles in each topic at the previous election. This means controlling for media attention in 2003 for the 2007 election, media attention in 2007 for the 2011 election, and so on. Both models are 
otherwise similar to model 2 in table 1, and are available in table A.3 in the appendix. These are essentially two strategies to control for previous public notoriety (and all factors that affect previous public notoriety). The results are the same as here.

Our last approach is to use fixed effects on each individual candidate, and thus control for any media- and preferential vote affinity the candidate may have. Essentially, then, we estimate whether a change in media attention within a topic leads to a change in the popularity of an individual candidate. This is arguably a very strong setup, but it also is a very restrictive one: It only allows us to model the effect of media attention on candidate popularity for candidates that participate in more than one election, as we focus on intra-candidate changes between elections. Substantially, we are then studying a specific and non-random subpopulation of the candidates. Practically, this also entails a dramatic reduction in observations, so much so that we have to merge the topics into two categories: Political articles and non-political articles (following the discussion above). What we find yields strong evidence in support of the competent voter hypothesis: While increased political coverage has a positive and statistically significant effect on a candidate's popularity, increased non-political coverage has no systematic relation to preferential votes. See the appendix for the full report of these results.

\section{Conclusion and Implications}

In this article, we have applied knowledge from the fields of psychology, political behaviour, and media studies, to investigate the nuanced role of media attention in an electoral setting.

Analysing a unique dataset, we first demonstrated that media attention is important for candidates that compete for office, and can have serious effects on their electoral fortunes. This is true even in a setting where voters have very few incentives to seek out - or act on - information on individual politicians. However, the estimated effects should not be exaggerated. Much of the variation in preferential votes is independent of media attention. Party cues, political experience of the candidate, etc., are all important sources of information for voters. This finding is, of course, of relevance to studies of media and political competition.

Second, we have highlighted that there are different kinds of media attention. Politicians may figure in articles on various political or apolitical topics. Voters do not respond similarly towards these different types of media coverage. Generally, we argue, voters seem to respond more 
positively towards candidates that somehow signal political capability or position. We believe that these findings are good news for democracy. It is clearly crucial to the functioning of democracy that voters hold politicians accountable. Our results suggest that they do - voters care about political information, and disregard apolitical information. Given the scepticism in parts of the political behaviour literature on behalf of voters' capabilities to make meaningful choices or hold meaningful attitudes, this finding is very important.

Nevertheless, to draw such broad conclusions we need similar studies from other contexts. While the choice of the local elections in Oslo was a strategical one, in the sense that we aimed to find a "least likely" case for effects of media exposure, there are some aspects of the case selection that may affect the findings. First, individuals from different political cultures may value different things. Being famous from business ventures could have much more positive effects in countries such as the US than "social-democratic" Norway. Second, the population of Oslo is - on average - relatively wealthy and well-educated. Perhaps less wealthy and well-educated voters respond differently to various types of media coverage. Finally, local elections in Norway are considered to be second-order elections (see Reif and Schmidt 1980). This may mean that voters use different cues for vote choice than they would in first-order elections, limiting the external validity of our findings. ${ }^{3}$ We thus urge other scholars to gather data and replicate our findings in other electoral contexts, for instance national elections in less party-centred political systems. Such studies must, of course, take into account key features of the context. Newspaper coverage may not be the best measure in places where fewer people read newspapers - perhaps television coverage would be more relevant. Studying social media coverage may also be fruitful in the years to come.

Third, we highlight that studies of media exposure and politics must take seriously the different types of media coverage a candidate may get - all PR is not necessarily good PR. We also point out that in order to evaluate the general impact that the media can have on electoral politics, it should be compared with other relevant sources of information that voters have access to. Finally, while we have investigated patterns in how voters, on average, respond to media attention, future research should aim to understand more nuanced patterns. It may well be that different segments of the voting population respond to differently to different types of media exposure. Perhaps the

\footnotetext{
${ }^{3} \mathrm{We}$ are indebted to one of the anonymous reviewers for pointing this out.
} 
effect varies by educational levels or other social background variables. Also, different kinds of candidates - e.g., men and women - may be rewarded for different types of media coverage. 


\section{References}

Achen, Christopher H. and Larry M. Bartels (2016), Democracy for Realists, Princeton University Press.

Aftenposten. (2018). Flere enn åtte av ti nordmenn leser norske medier hver dag. [online] Available at: https://www.aftenposten.no/kultur/i/6g6KQ/Flere-enn-atte-av-ti-nordmennleser-norske-medier-hver-dag [Accessed 19 Sep. 2018].

Ansolabehere, S., R. Behr, and S. Iyengar (1993). The media game: American politics in the television age. New York: Macmillan.

Baum, Matthew A. and Angela S. Jamison (2006), 'The Operah effect: How soft news helps inattentive citizens vote consistently', The Journal of Politics 68(4), 946-959.

Berelson, Bernard R., Paul F. Lazarsfeld and William N. McPhee (1954), Voting. A Study of Opinion Formation in a Presidential Campaign, The University of Chicago Press.

Bergh, Johannes, Tor Bjørklund and Ottar Hellevik (2010), 'Personutvelgingen i norske valg', Norsk statsvitenskapelig tidsskrift 26(02), 105-131.

Bjørn Erik Rasch (1999), 'Electoral Systems, Parliamentary Committees, and Party Discipline: The Norwegian Storting in a Comparative Perspective', in Party Discipline and Parliamentary Government, ed. Shaun Bowler, David M. Farrell and Richard S. Katz, eds,, Ohio State University Press.

Blei, David M. (2012), 'Probabilistic topic models', Communications of the ACM 55(4), 77.

Campbell, Angus, Philip E. Converse, Warren Miller and Donald E. Stokes (1960), The American Voter: Unabridged Edition, The University of Chicago Press.

Cohen, B. (1963). The press and foreign policy. Princeton: Princeton University.

Conover, P.J. and S. Feldman (1989). 'Candidate perception in an ambiguous world: Campaigns, cues, and inference processes', American Journal of Political Science, 912-940.

Converse, Paul E. (1964), 'The Nature of Belief Systems in Mass Publics' in Ideology and Discontent, ed. David E. Apter. New York: The Free Press of Glencoe. 
D'Alessio, D. and M. Allen (2000). 'Media bias in presidential elections: A meta-analysis', Journal of Communication, 50, 133-156.

Druckman, J. N. (2001). 'The implications of framing effects for citizen competence', Political Behavior, 23, 225-256.

Eberl, J-M., H.G. Boomgarden, and M. Wagner (2017). 'One Bias Fits All? Three Types of Media Bias and Their Effects on Party Preferences', Communication Research, 44(8), $1125-1148$.

Fiva, Jon and Helene L. Røhr (2018), 'Climbing the ranks: Incumbency effects in party-list systems', European Economic Review 101, 142 - 156

Fowler, Anthony and Andrew B. Hall (2017), 'Do Shark Attacks Influence Presidential Elections? Reassessing a Prominent Finding on Voter Competence'. Working paper. Available at http://www.andrewbenjaminhall.com/FowlerHall_Sharks.pdf

Fowler, Anthony and Pablo B. Montagnes (2015), 'College football, elections, and false-positive results in observational research', Proceedings of the National Academy of Sciences 112, 13800-13804.

Goldstein, David G. and Gerd Gigerenzer (2002), 'Models of ecological rationality: the recognition heuristic.', Psychological review 109(1), 75-90

Goren, Paul (2013), On Voter Competence, Oxford University Press.

Hackett, R.A. (1984). 'Decline of a paradigm? Bias and objectivity in news media studies.' Critical Studies in Mass Communication, 1, 229-259.

Hansen, K.M. and R.T. Pedersen (2014). 'Campaigns matter: How voters become knowledgeable and efficacious during election campaigns', Political Communication 31(2), 303-324.

Healy, Andrew J., Neil Malhotra and Cecilia H. Mo (2010), 'Irrelevant events affect voters' evaluations of government performance', Proceedings of the National Academy of Sciences 107(29), 12804-12809. URL: http://dx.doi.org/10.1073/pnas.1007420107 
Hopmann, David N., Riens Vliegenthart, Claes De Vreese and Erik Albæk (2010), 'Effects of Election News Coverage: How Visibility and Tone Influence Party Choice', Political Communication 27(4), 389405.

Hopmann, D.N., P. Van Aelst, and G. Legnante (2011). 'Political balance in the news: A review of concepts, operationalizations and key findings', Journalism, 13, 240-257.

Huckfeldt, R.R. and J. Sprague (1995). Citizens, politics and social communication: Information and influence in an election campaign. Cambridge University Press.

Iyengar, S. and D.R. Kinder (2010). News That Matters. Television \& American Opinion. Updated edition. Chicago: University of Chicago Press.

Kam, Cindy and Elizabeth J. Zechmeister (2013), 'Name recognition and candidate support', American Journal of Political Science 57(4), 971-986.

Karlsen, Rune (2017), 'Mediebruk i lokalvalgkampen 2015: informasjon om politikk og kandidater', in Lokalvalget 2015 - et valg I kommunereformens tegn? Ed. Jo Saglie and Dag Arne Christensen, Oslo: Abstrakt forlag.

Kunst-Wilson, William R. and Zajonc, Robert B. (1980), 'Affective Discrimination of Stimuli that cannot be Recognized', Science 207(4430), 557-558.

Lovdata.no. (2018). Lov om valg til Stortinget, fylkesting og kommunestyrer (valgloven) Lovdata. [online] Available at: https://lovdata.no/dokument/NL/lov/2002-06-28-57 [Accessed 19 Sep. 2018].

Lupia, Arthur (2003),' Delegation and its Perils', in Delegation and Accountability in Parliamentary Democracies ed. Kaare Strøm, Wolfgang C. Müller and Torbjörn Bergman, Oxford University Press Oxford, chapter 2, pp. 33-54.

Luskin, Robert (2002), From Denial to Extenuation (and Finally Beyond): Political Sophistication and Citizen Performance in Thinking about Political Psychology ed. James Kuklinski, Cambridge University Press, pp. 281-305.

Maddens, Bart, Bram Wauters, Jo Noppe and Stefaan Fiers (2006), 'Effects of Campaign Spending in an Open List PR System: The 2003 Legislative Elections in Flanders/Belgium', West European Politics 29(1), 161168. 
Marshall, David P. (1997), Celebrity And Power: Fame and Contemporary Culture, University Of Minnesota Press.

Næss, Arne (1953), Interpretation and Preciseness, Oslo: Univeristetets Studentkontor.

Norris, Pippa, John Curtice, David Sanders, Margaret Scammell, and Holli A. Semetko (1999), On message: Communicating the campaign, New York: Sage.

Oegema, Dirk and Jan Kleinnijenhuis (2000), 'Personalization in political Television News: A 13-Wave Survey Study to Assess Effects of Text and Footage', Communications 25(1).

Oslo kommune. (2018). Startsiden. [online] Available at: https://www.oslo.kommune.no/ [Accessed 19 Sep. 2018].

Page, Benjamin I. and Shapiro, Robert Y. (1992), The Rational Public: Fifty Years of Trends in Americans' Policy Preferences, University of Chicago Press.

Pease, Andrew and Paul R. Brewer (2008), 'The Operah factor: The effects of a celebrity endorsement in a presidential primary campaign', International Journal of Press/Politics 13(4), 385-400.

Popkin, Samuel L. (1991), The Reasoning Voter: Communication and Persuasion in Presidential Campaigns, University of Chicago Press.

Reeves, R. (1997). 'The question of media bias', in S. Iyengar and R. Reeves (eds.). Do the media govern? Politicians, voters, and reporters in America. New York: Cambridge University Press.

Retriever Norge. (2018). Mediearkiv - Retriever Norge. [online] Available at: https://www.retriever.no/product/mediearkiv/ [Accessed 19 Sep. 2018].

Roberts, Margaret E., Brandon M. Stewart and Dustin Tingley (2018). Stm: R Package for Structural Topic Models. URL: http://www.structuraltopicmodel.com

Semetko, Holli A. and Klaus Schönbach (1994), Germany's unity election: Voters and the media, Hampton Press.

Sniderman, Paul M., Richard A. Brody and Philip E. Tetlock (1991), Reasoning and Choice: Explorations in Political Psychology, Cambridge University Press. 
Søyland, Martin G. and Emanuele Lapponi (2017), Party polarization and parliamentary speech. Working paper. Available at https://ecpr.eu/Events/PaperDetails.aspx?PaperID=36633\&EventID=96

Van Aelst, Peter, Bart Maddens, Jo Noppe, and Stefaan Fiers (2008), 'Politicians in the News: Media or Party Logic?: Media Attention and Electoral Success in the Belgian Election Campaign of 2003', European Journal of Communication 23(2), 193210.

Weinberger, Joel and Drew Westen (2008), 'RATS, we should have used Clinton: Subliminal priming in political campaigns', International Society of Political Psychology 29(5), 631651.

West, Darrell M. and John M. Orman (2002), Celebrity Politics. Prentice Hall.

Zajonc, Robert B. (1968), 'Attitudinal effects of mere exposure', Journal of personality and social psychology 9(2p2), 1. 


\section{Online appendix for "Is all PR good PR? How the content of media exposure affects candidate popularity."}

In this online appendix, we provide additional information about the data and robustness tests that are mentioned, but not displayed in tables, in the paper.

\section{A.1 Descriptive statistics}

Table A.1: Descriptive statistics

\begin{tabular}{|c|c|c|c|c|c|c|}
\hline Variable & Mean & Median & SD & Min & Max & $\begin{array}{r}N \\
\text { missing }\end{array}$ \\
\hline Preferential votes & 221.35 & 74.00 & 446.70 & 0.00 & 6947.00 & 0.00 \\
\hline Swing-votes & 19.16 & 7.00 & 39.70 & 0.00 & 523.00 & 0.00 \\
\hline $\begin{array}{l}\text { 22nd July } \\
\text { (Depreciation } 0.925 \text { ) }\end{array}$ & 1.13 & 0.00 & 21.89 & 0.00 & 720.47 & 0.00 \\
\hline $\begin{array}{l}\text { Immigration } \\
\text { (Depreciation 0.925) }\end{array}$ & 1.47 & 0.02 & 11.46 & 0.00 & 352.41 & 0.00 \\
\hline $\begin{array}{l}\text { Health and technology } \\
\text { (Depreciation } 0.925 \text { ) }\end{array}$ & 1.55 & 0.05 & 9.71 & 0.00 & 258.32 & 0.00 \\
\hline $\begin{array}{l}\text { Cultural review } \\
\text { (Depreciation 0.925) }\end{array}$ & 1.21 & 0.00 & 9.05 & 0.00 & 162.02 & 0.00 \\
\hline $\begin{array}{l}\text { Football } \\
\text { (Depreciation 0.925) }\end{array}$ & 2.16 & 0.00 & 54.03 & 0.00 & 2332.60 & 0.00 \\
\hline $\begin{array}{l}\text { Court cases } \\
\text { (Depreciation 0.925) }\end{array}$ & 2.50 & 0.01 & 36.78 & 0.00 & 1264.52 & 0.00 \\
\hline $\begin{array}{l}\text { Urban planning } \\
\text { (Depreciation 0.925) }\end{array}$ & 2.37 & 0.24 & 9.48 & 0.00 & 232.55 & 0.00 \\
\hline $\begin{array}{l}\text { Emergencies } \\
\text { (Depreciation 0.925) }\end{array}$ & 1.66 & 0.02 & 14.63 & 0.00 & 519.56 & 0.00 \\
\hline $\begin{array}{l}\text { Profile features } \\
\text { (Depreciation 0.925) }\end{array}$ & 2.62 & 0.20 & 12.22 & 0.00 & 279.85 & 0.00 \\
\hline
\end{tabular}


Big business

(Depreciation 0.925)

Energy policies

(Depreciation 0.925)

New Norwegian

(Depreciation 0.925)

Education

(Depreciation 0.925)

Portfolio negotiations

(Depreciation 0.925)

Infrastructure

(Depreciation 0.925)

Urban-rural

(Depreciation 0.925)

Economic analyses

(Depreciation 0.925)

National politics

(Depreciation 0.925)

Intellectual

(Depreciation 0.925)

22nd July

(Depreciation 0.7)

Immigration

(Depreciation 0.7)

Health and technology

(Depreciation 0.7)

Cultural review

(Depreciation 0.7)

Football

0.57

(Depreciation 0.7) $\begin{array}{llllll}1.39 & 0.01 & 33.49 & 0.00 & 1446.36 & 0.00\end{array}$

$\begin{array}{llllll}1.24 & 0.03 & 10.26 & 0.00 & 394.17 & 0.00\end{array}$

$\begin{array}{llllll}0.74 & 0.00 & 3.52 & 0.00 & 69.55 & 0.00\end{array}$

$\begin{array}{llllll}1.41 & 0.05 & 10.37 & 0.00 & 340.00 & 0.00\end{array}$

$\begin{array}{llllll}1.59 & 0.01 & 29.62 & 0.00 & 1234.75 & 0.00\end{array}$

$\begin{array}{llllll}0.66 & 0.01 & 5.74 & 0.00 & 140.86 & 0.00\end{array}$

$\begin{array}{llllll}0.76 & 0.01 & 5.03 & 0.00 & 90.64 & 0.00\end{array}$

$\begin{array}{llllll}0.79 & 0.01 & 7.59 & 0.00 & 290.55 & 0.00\end{array}$

$\begin{array}{llllll}1.93 & 0.16 & 15.31 & 0.00 & 569.82 & 0.00\end{array}$

$\begin{array}{llllll}2.69 & 0.06 & 14.77 & 0.00 & 247.16 & 0.00\end{array}$

$\begin{array}{llllll}0.25 & 0.00 & 3.77 & 0.00 & 121.76 & 0.00\end{array}$

$\begin{array}{llllll}0.33 & 0.00 & 2.57 & 0.00 & 70.81 & 0.00\end{array}$

$\begin{array}{llllll}0.35 & 0.00 & 2.15 & 0.00 & 58.22 & 0.00\end{array}$

$\begin{array}{llllll}0.26 & 0.00 & 2.32 & 0.00 & 70.46 & 0.00\end{array}$


Court cases

(Depreciation 0.7)

Urban planning

(Depreciation 0.7)

Emergencies

$0.37 \quad 0.00$

$0.63 \quad 0.02$

$2.94 \quad 0.00$

69.86

0.00

(Depreciation 0.7)

Big business

$0.36 \quad 0.00$

$7.66 \quad 0.00$

314.16

0.00

(Depreciation 0.7)

Energy policies

$0.28 \quad 0.00$

$2.47 \quad 0.00$

90.11

0.00

(Depreciation 0.7)

New Norwegian

0.18

0.00

$0.98 \quad 0.00$

18.34

0.00

(Depreciation 0.7)

Education

0.32

0.00

$2.55 \quad 0.00$

78.50

0.00

(Depreciation 0.7)

Portfolio negotiations

$0.35 \quad 0.00$

$7.19 \quad 0.00$

298.28

0.00

(Depreciation 0.7)

Infrastructure

$0.17 \quad 0.00$

$1.69 \quad 0.00$

44.78

0.00

(Depreciation 0.7)

Urban-rural

0.19

0.00

$1.61 \quad 0.00$

50.67

0.00

(Depreciation 0.7)

Economic analyses

$0.18 \quad 0.00$

$2.16 \quad 0.00$

87.81

0.00

(Depreciation 0.7)

National politics

$\begin{array}{ll}0.56 & 0.02\end{array}$

$6.17 \quad 0.00$

257.27

0.00

(Depreciation 0.7)

Intellectual

0.61

0.01

$3.53 \quad 0.00$

84.38

0.00

(Depreciation 0.7)

Cumulated number of articles

Ranked last

$\begin{array}{rrrrrr}505.02 & 23.00 & 2597.71 & 0.00 & 46514.00 & 0.00 \\ 0.03 & 0.00 & 0.16 & 0.00 & 1.00 & 0.00 \\ 23.96 & 22.00 & 15.76 & 1.00 & 62.00 & 0.00\end{array}$

$\begin{array}{lllllll}\text { Distance to cumulated position } & 23.96 & 22.00 & 15.76 & 1.00 & 62.00 & 0.00\end{array}$ 


\begin{tabular}{|c|c|c|c|c|c|c|}
\hline Incumbent & 0.02 & 0.00 & 0.14 & 0.00 & 1.00 & 0.00 \\
\hline Participated in previous election & 0.26 & 0.00 & 0.44 & 0.00 & 1.00 & 0.00 \\
\hline Sex $($ Male $=1)$ & 0.57 & 1.00 & 0.49 & 0.00 & 1.00 & 0.00 \\
\hline Age $60+$ & 0.25 & 0.00 & 0.43 & 0.00 & 1.00 & 0.00 \\
\hline Age $18-29$ & 0.18 & 0.00 & 0.39 & 0.00 & 1.00 & 0.00 \\
\hline Age $30-39$ & 0.23 & 0.00 & 0.42 & 0.00 & 1.00 & 0.00 \\
\hline Age $40-49$ & 0.18 & 0.00 & 0.38 & 0.00 & 1.00 & 0.00 \\
\hline Age $50-59$ & 0.16 & 0.00 & 0.36 & 0.00 & 1.00 & 0.00 \\
\hline Election 2007 & 0.38 & 0.00 & 0.49 & 0.00 & 1.00 & 0.00 \\
\hline Election 2011 & 0.31 & 0.00 & 0.46 & 0.00 & 1.00 & 0.00 \\
\hline Election 2015 & 0.31 & 0.00 & 0.46 & 0.00 & 1.00 & 0.00 \\
\hline Origin: Norway & 0.77 & 1.00 & 0.42 & 0.00 & 1.00 & 0.00 \\
\hline Origin: Africa & 0.04 & 0.00 & 0.19 & 0.00 & 1.00 & 0.00 \\
\hline Origin: Asia & 0.06 & 0.00 & 0.23 & 0.00 & 1.00 & 0.00 \\
\hline Origin: North America & 0.01 & 0.00 & 0.10 & 0.00 & 1.00 & 0.00 \\
\hline Origin: Oceania & 0.00 & 0.00 & 0.06 & 0.00 & 1.00 & 0.00 \\
\hline Origin: Eastern Europe & 0.02 & 0.00 & 0.13 & 0.00 & 1.00 & 0.00 \\
\hline Origin: Latin-Amrica & 0.02 & 0.00 & 0.13 & 0.00 & 1.00 & 0.00 \\
\hline Origin: Western Europe & 0.08 & 0.00 & 0.28 & 0.00 & 1.00 & 0.00 \\
\hline Party: Arbeiderpartiet & 0.08 & 0.00 & 0.27 & 0.00 & 1.00 & 0.00 \\
\hline Party: Demokratisk Alternativ for & 0.00 & 0.00 & 0.06 & 0.00 & 1.00 & 0.00 \\
\hline \multicolumn{7}{|l|}{ Oslo } \\
\hline Party: Demokratene & 0.05 & 0.00 & 0.21 & 0.00 & 1.00 & 0.00 \\
\hline Party: Det liberale folkepartiet & 0.01 & 0.00 & 0.11 & 0.00 & 1.00 & 0.00 \\
\hline Party: Feministisk initiativ & 0.01 & 0.00 & 0.11 & 0.00 & 1.00 & 0.00 \\
\hline Party: Fremskrittspartiet & 0.06 & 0.00 & 0.24 & 0.00 & 1.00 & 0.00 \\
\hline Party: Høyre & 0.09 & 0.00 & 0.28 & 0.00 & 1.00 & 0.00 \\
\hline Party: Innvandrerpartiet & 0.01 & 0.00 & 0.07 & 0.00 & 1.00 & 0.00 \\
\hline Party: Kystpartiet & 0.05 & 0.00 & 0.21 & 0.00 & 1.00 & 0.00 \\
\hline Party: Kristelig Folkeparti & 0.09 & 0.00 & 0.29 & 0.00 & 1.00 & 0.00 \\
\hline Party: Kristent Samlingsparti & 0.01 & 0.00 & 0.12 & 0.00 & 1.00 & 0.00 \\
\hline
\end{tabular}




$\begin{array}{lllllll}\text { Party: Liberalistene Oslo } & 0.00 & 0.00 & 0.06 & 0.00 & 1.00 & 0.00 \\ \text { Party: Miljøpartiet de Grønne } & 0.09 & 0.00 & 0.28 & 0.00 & 1.00 & 0.00 \\ \text { Party: Norges kommunistiske parti } & 0.03 & 0.00 & 0.16 & 0.00 & 1.00 & 0.00 \\ \text { Party: Oslo Byaksjon } & 0.03 & 0.00 & 0.17 & 0.00 & 1.00 & 0.00 \\ \text { Party: Piratpartiet } & 0.01 & 0.00 & 0.10 & 0.00 & 1.00 & 0.00 \\ \text { Party: Pensjonistpartiet } & 0.05 & 0.00 & 0.21 & 0.00 & 1.00 & 0.00 \\ \text { Party: Rødt } & 0.08 & 0.00 & 0.28 & 0.00 & 1.00 & 0.00 \\ \text { Party: Samfunnspartiet } & 0.01 & 0.00 & 0.10 & 0.00 & 1.00 & 0.00 \\ \text { Party: Senterpartiet } & 0.08 & 0.00 & 0.27 & 0.00 & 1.00 & 0.00 \\ \text { Party: Sosialistisk Venstreparti } & 0.07 & 0.00 & 0.26 & 0.00 & 1.00 & 0.00 \\ \text { Party: Venstre } & 0.09 & 0.00 & 0.29 & 0.00 & 1.00 & 0.00\end{array}$


Table A.2: The political relevance of topics.

\begin{tabular}{|l|l|}
\hline Topic & Politically relevant? \\
\hline Business & No \\
\hline Court cases & No \\
\hline Cultural events & No \\
\hline Economic analyses & Yes \\
\hline Education & Yes \\
\hline Energy policies & Yes \\
\hline Football & No \\
\hline Health and technology & Yes \\
\hline Immigration & Yes \\
\hline Intellectual & Yes \\
\hline Infrastructure & Yes \\
\hline National politics & Yes \\
\hline New Norwegian & Yes \\
\hline Portfolio negotiations & Yes \\
\hline Profile features & Yes \\
\hline Urban planning & \\
\hline Urban-rural & Yes \\
\hline
\end{tabular}




\begin{tabular}{|c|c|c|}
\hline & Model 1 & Model 2 \\
\hline \multirow{2}{*}{ Ln National politics } & $0.13^{* *}$ & $0.13^{* *}$ \\
\hline & $(0.05)$ & $(0.05)$ \\
\hline \multirow{2}{*}{ Ln Intellectual } & 0.08 & 0.08 \\
\hline & $(0.05)$ & $(0.05)$ \\
\hline \multirow{2}{*}{ Ln Profile features } & $0.14^{*}$ & $0.15^{*}$ \\
\hline & $(0.06)$ & $(0.06)$ \\
\hline \multirow[t]{2}{*}{ Ln Urban-rural } & 0.09 & 0.11 \\
\hline & $(0.06)$ & $(0.06)$ \\
\hline \multirow[t]{2}{*}{ Ln 22nd July } & 0.09 & 0.04 \\
\hline & $(0.06)$ & $(0.06)$ \\
\hline \multirow{2}{*}{ Ln New Norwegian } & 0.05 & 0.03 \\
\hline & $(0.05)$ & $(0.06)$ \\
\hline \multirow[t]{2}{*}{ Ln Immigration } & $0.10^{*}$ & 0.08 \\
\hline & $(0.04)$ & $(0.05)$ \\
\hline \multirow[t]{2}{*}{ Ln Urban planning } & $0.07^{*}$ & $0.10^{* * *}$ \\
\hline & $(0.03)$ & $(0.03)$ \\
\hline \multirow[t]{2}{*}{ Ln Business } & 0.02 & -0.01 \\
\hline & $(0.05)$ & $(0.06)$ \\
\hline \multirow[t]{2}{*}{ Ln Cultural reviews } & -0.02 & -0.03 \\
\hline & $(0.05)$ & $(0.06)$ \\
\hline \multirow{2}{*}{ Ln Court cases } & 0.02 & -0.02 \\
\hline & $(0.05)$ & $(0.05)$ \\
\hline \multirow[t]{2}{*}{ Ln Health and technology } & -0.02 & -0.004 \\
\hline & $(0.04)$ & $(0.04)$ \\
\hline \multirow[t]{2}{*}{ Ln Education } & -0.03 & -0.02 \\
\hline & $(0.05)$ & $(0.05)$ \\
\hline \multirow[t]{2}{*}{ Ln Energy policies } & -0.03 & -0.05 \\
\hline & $(0.06)$ & $(0.06)$ \\
\hline \multirow[t]{2}{*}{ Ln Economic analyses } & -0.06 & -0.06 \\
\hline & $(0.06)$ & $(0.06)$ \\
\hline \multirow[t]{2}{*}{ Ln Portfolio negotiations } & $-0.12^{*}$ & -0.06 \\
\hline & $(0.05)$ & $(0.05)$ \\
\hline \multirow{2}{*}{ Ln Infrastructure } & -0.07 & -0.05 \\
\hline & $(0.06)$ & $(0.06)$ \\
\hline \multirow[t]{2}{*}{ Ln Emergencies } & -0.09 & -0.09 \\
\hline & $(0.05)$ & $(0.05)$ \\
\hline \multirow[t]{2}{*}{ Ln Football } & -0.09 & $-0.12^{*}$ \\
\hline & $(0.05)$ & $(0.05)$ \\
\hline \multirow[t]{2}{*}{ Ln National politics 2003} & 0.07 & \\
\hline & $(0.08)$ & \\
\hline \multirow[t]{2}{*}{ Ln Intellectual 2003} & 0.13 & \\
\hline & $(0.08)$ & \\
\hline \multirow[t]{2}{*}{ Ln Profile features 2003} & 0.10 & \\
\hline & $(0.10)$ & \\
\hline Ln Urban-rural 2003 & 0.14 & \\
\hline & $(0.10)$ & \\
\hline Ln 22nd July 2003 & -0.20 & \\
\hline & $(0.29)$ & \\
\hline Ln New Norwegian 2003 & 0.16 & \\
\hline & $(0.13)$ & \\
\hline
\end{tabular}


Ln Immigration 2003

$(0.07)$

Ln Urban planning 2003

Ln Business $2003 \quad-0.02$

Ln Cultural reviews 2003

$(0.10)$

Ln Court cases $2003 \quad-0.02$

2003

Ln Health and technology $2003 \quad 0.07$

Ln Education 2003

$-0.06$

$(0.08)$

$-0.13$

$(0.11)$

0.004

$(0.06)$

$0.18^{*}$

(0.09)

$-0.12$

$(0.11)$

$\begin{array}{ll}\text { Ln Emergencies } 2003 & -0.05 \\ & (0.11)\end{array}$

Ln Football $2003 \quad-0.12$

Ln National politics at previous election $\quad 0.01$

Ln Intellectual previous election $\quad 0.12$

Ln Profile features previous election

$-0.02$

$(0.07)$

0.04

$(0.08)$

0.002

$(0.07)$

0.12

$(0.07)$

$-0.03$

$(0.05)$

$-0.07^{*}$

(0.03)

0.11

(0.07)

0.11

(0.07)

0.04

(0.06)

$-0.02$

(0.06)

$-0.02$

(0.05)

0.03

(0.06)

0.01

(0.05) 


\begin{tabular}{|c|c|c|}
\hline Ln Portfolio negotiations previous election & & $\begin{array}{l}-0.03 \\
(0.06)\end{array}$ \\
\hline Ln Infrastructure previous election & & $\begin{array}{c}-0.12 \\
(0.07)\end{array}$ \\
\hline Ln Emergencies previous election & & $\begin{array}{c}0.01 \\
(0.06)\end{array}$ \\
\hline Ln Football previous election & & $\begin{array}{l}-0.04 \\
(0.06)\end{array}$ \\
\hline Ranked last & $\begin{array}{l}0.38^{* * *} \\
(0.10)\end{array}$ & $\begin{array}{c}0.37^{* * * *} \\
(0.09)\end{array}$ \\
\hline Distance to cumulated position & $\begin{array}{l}-0.03^{* * *} \\
(0.001)\end{array}$ & $\begin{array}{l}-0.03^{* * * *} \\
(0.001)\end{array}$ \\
\hline Incumbent & $\begin{array}{c}0.14 \\
(0.11)\end{array}$ & $\begin{array}{l}0.20 \\
(0.11)\end{array}$ \\
\hline Participated in previous election & $\begin{array}{l}0.11^{* * * *} \\
(0.03)\end{array}$ & $\begin{array}{l}0.13^{* * *} \\
(0.03)\end{array}$ \\
\hline Male & $\begin{array}{l}-0.14^{* * * *} \\
(0.03)\end{array}$ & $\begin{array}{c}-0.13^{* * * *} \\
(0.03)\end{array}$ \\
\hline Age & $\begin{array}{l}-0.05^{* * *} \\
(0.01)\end{array}$ & $\begin{array}{c}-0.05^{* * * *} \\
(0.01)\end{array}$ \\
\hline Constant & $\begin{array}{l}6.83^{* * * *} \\
(0.06)\end{array}$ & $\begin{array}{l}6.83^{* * * *} \\
(0.06)\end{array}$ \\
\hline Election Year FE & Yes & Yes \\
\hline Party FE & Yes & Yes \\
\hline Region of origin FE & Yes & Yes \\
\hline $\begin{array}{l}\text { Observations } \\
\mathbf{R}^{2}\end{array}$ & $\begin{array}{l}1,900 \\
0.90\end{array}$ & $\begin{array}{c}1,900 \\
0.90\end{array}$ \\
\hline Note: & $\begin{array}{l}0.90 \\
{ }^{*} \mathrm{p}<1 \\
\text { st stanc }\end{array}$ & $\begin{array}{l}0.90 \\
1 ;{ }^{* * *} \mathrm{p}< \\
1 \text { parent }\end{array}$ \\
\hline
\end{tabular}


Ln Political topics

Ln Nonpolitical topics

Ranked last

Distance to cumulated position

Incumbent

Participated in previous election

Age

Constant

Candidate FE

Election year FE

Degrees of freedom

Observations

$\mathbf{R}^{2}$

Note:
Model 1

$0.07^{* *}$

$(0.03)$

0.001

$(0.05)$

0.32

$(0.17)$

$-0.02^{* * *}$

$(0.002)$

$-0.18^{*}$

$(0.07)$

0.04

$(0.04)$

0.03

(0.05)

$6.41^{* * *}$

(0.16)

Yes

376

699

0.96

${ }^{*} \mathrm{p}<0.05 ;{ }^{* *} \mathrm{p}<0.01 ;{ }^{* * *} \mathrm{p}<0.001$

Robust standard errors in parentheses. 
Table A.5 Multilevel models of our benchmark models.

\begin{tabular}{|c|c|c|c|}
\hline & Model 1 & Model 2 & Model 3 \\
\hline Ln number of articles & $\begin{array}{c}0.16^{* * *} \\
(0.01)\end{array}$ & & \\
\hline Ln National politics & & $\begin{array}{l}0.14^{* * *} \\
(0.04)\end{array}$ & $\begin{array}{l}0.23^{* * *} \\
(0.06)\end{array}$ \\
\hline Ln Intellectual & & $\begin{array}{l}0.15^{\text {*** }} \\
(0.04)\end{array}$ & $\begin{array}{l}0.27^{* * *} \\
(0.05)\end{array}$ \\
\hline Ln Profile features & & $\begin{array}{l}0.14^{* *} \\
(0.05)\end{array}$ & $\begin{array}{l}0.24^{\text {***** }} \\
(0.07)\end{array}$ \\
\hline Ln Urban-rural & & $\begin{array}{l}0.13^{\text {** }} \\
(0.04)\end{array}$ & $\begin{array}{l}0.26^{* * * *} \\
(0.07)\end{array}$ \\
\hline Ln 22nd July & & $\begin{array}{c}0.08 \\
(0.05)\end{array}$ & $\begin{array}{l}-0.01 \\
(0.06)\end{array}$ \\
\hline Ln New Norwegian & & $\begin{array}{l}0.09^{*} \\
(0.04)\end{array}$ & $\begin{array}{c}0.01 \\
(0.07)\end{array}$ \\
\hline Ln Immigration & & $\begin{array}{c}0.07^{*} \\
(0.04)\end{array}$ & $\begin{array}{l}0.13^{*} \\
(0.06)\end{array}$ \\
\hline Ln Urban planning & & $\begin{array}{l}0.07^{* *} \\
(0.03)\end{array}$ & $\begin{array}{l}0.11^{* * *} \\
(0.04)\end{array}$ \\
\hline Ln Business & & $\begin{array}{c}0.03 \\
(0.04)\end{array}$ & $\begin{array}{c}0.02 \\
(0.06)\end{array}$ \\
\hline Ln Cultural reviews & & $\begin{array}{c}0.04 \\
(0.04)\end{array}$ & $\begin{array}{c}0.09 \\
(0.06)\end{array}$ \\
\hline Ln Court cases & & $\begin{array}{c}0.02 \\
(0.04)\end{array}$ & $\begin{array}{c}0.04 \\
(0.05)\end{array}$ \\
\hline Ln Health and technology & & $\begin{array}{c}-0.02 \\
(0.03)\end{array}$ & $\begin{array}{l}-0.04 \\
(0.06)\end{array}$ \\
\hline Ln Education & & $\begin{array}{l}-0.04 \\
(0.04)\end{array}$ & $\begin{array}{l}-0.09 \\
(0.07)\end{array}$ \\
\hline Ln Energy policies & & $\begin{array}{l}-0.05 \\
(0.05)\end{array}$ & $\begin{array}{l}-0.03 \\
(0.08)\end{array}$ \\
\hline Ln Economic analyses & & $\begin{array}{l}-0.06 \\
(0.05)\end{array}$ & $\begin{array}{l}-0.07 \\
(0.08)\end{array}$ \\
\hline Ln Portfolio negotiations & & $\begin{array}{l}-0.08^{*} \\
(0.04)\end{array}$ & $\begin{array}{l}-0.11 \\
(0.07)\end{array}$ \\
\hline Ln Infrastructure & & $\begin{array}{c}-0.08 \\
(0.05)\end{array}$ & $\begin{array}{l}-0.06 \\
(0.07)\end{array}$ \\
\hline Ln Emergencies & & $\begin{array}{l}-0.11^{*} \\
(0.04)\end{array}$ & $\begin{array}{l}-0.19^{* *} \\
(0.07)\end{array}$ \\
\hline Ln Football & & $\begin{array}{c}-0.15^{* * *} \\
(0.04)\end{array}$ & $\begin{array}{c}-0.26^{* * *} \\
(0.06)\end{array}$ \\
\hline Ranked last & $\begin{array}{l}0.48^{* * * *} \\
(0.09)\end{array}$ & $\begin{array}{l}0.38^{* * *} \\
(0.09)\end{array}$ & $\begin{array}{l}0.39^{* * * *} \\
(0.09)\end{array}$ \\
\hline
\end{tabular}




\begin{tabular}{|c|c|c|c|}
\hline Distance to cumulated position & $\begin{array}{l}-0.02^{* * *} \\
(0.001)\end{array}$ & $\begin{array}{l}-0.03^{* * * *} \\
(0.001)\end{array}$ & $\begin{array}{l}-0.03^{* * *} \\
(0.001)\end{array}$ \\
\hline Incumbent & $\begin{array}{l}0.32^{* *} \\
(0.10)\end{array}$ & $\begin{array}{c}0.21^{*} \\
(0.10)\end{array}$ & $\begin{array}{l}0.24^{*} \\
(0.10)\end{array}$ \\
\hline Participated in previous election & $\begin{array}{c}0.12^{* * * *} \\
(0.03)\end{array}$ & $\begin{array}{l}0.12^{* * * *} \\
(0.03)\end{array}$ & $\begin{array}{c}0.12^{* * * *} \\
(0.03)\end{array}$ \\
\hline Male & $\begin{array}{c}-0.13^{* * * *} \\
(0.03)\end{array}$ & $\begin{array}{c}-0.12^{* * * *} \\
(0.03)\end{array}$ & $\begin{array}{c}-0.12^{* * * *} \\
(0.03)\end{array}$ \\
\hline Age & $\begin{array}{c}-0.04^{* * * *} \\
(0.01)\end{array}$ & $\begin{array}{c}-0.05^{* * * *} \\
(0.01)\end{array}$ & $\begin{array}{c}-0.04^{* * *} \\
(0.01)\end{array}$ \\
\hline Constant & $\begin{array}{c}3.78^{* * * *} \\
(0.35)\end{array}$ & $\begin{array}{l}3.89^{* * * *} \\
(0.35)\end{array}$ & $\begin{array}{c}3.93^{* * * *} \\
(0.36)\end{array}$ \\
\hline Region of origin $\mathrm{FE}$ & Yes & No & No \\
\hline Observations & 1,900 & 1,900 & 1,900 \\
\hline
\end{tabular}

\section{A.4 Outlet Sensitivity}

In this section we investigate how sensitive our results are to individual outlets. In a series of regressions, we leave out each individual outlet one by one, and re-estimate model 2 from table 1 . Due to limits in computational power, all outlets with $<1000$ articles were combined into one category and treated as "one" outlet (and excluded in one of the estimations just as the other outlets). This procedure accumulates to 173 different models, each with a unique outlet excluded. In Figures A.1 - A.19, we illustrate the resulting distributions for the point-estimates and T-values for the 19 different topicvariables.
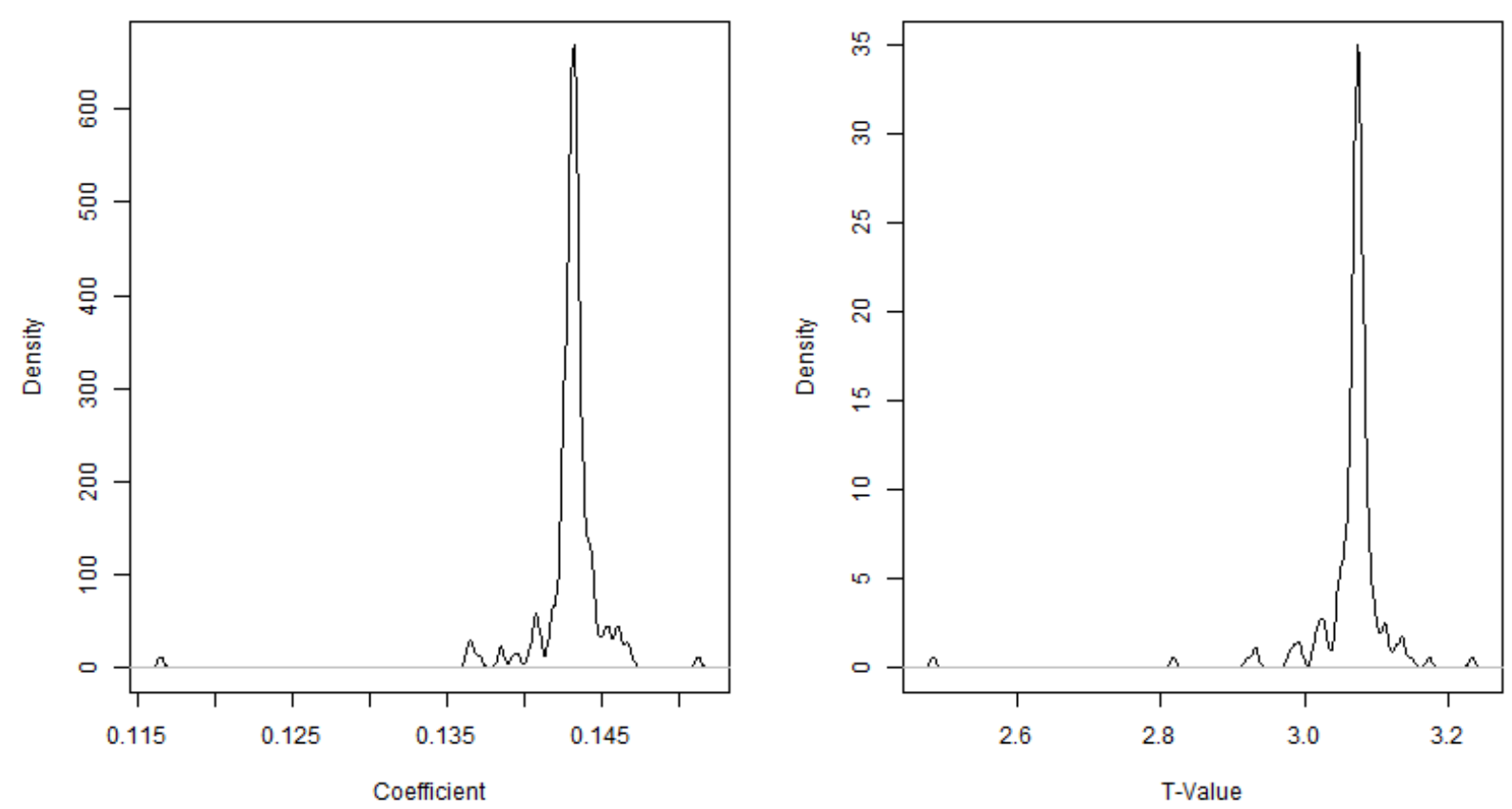

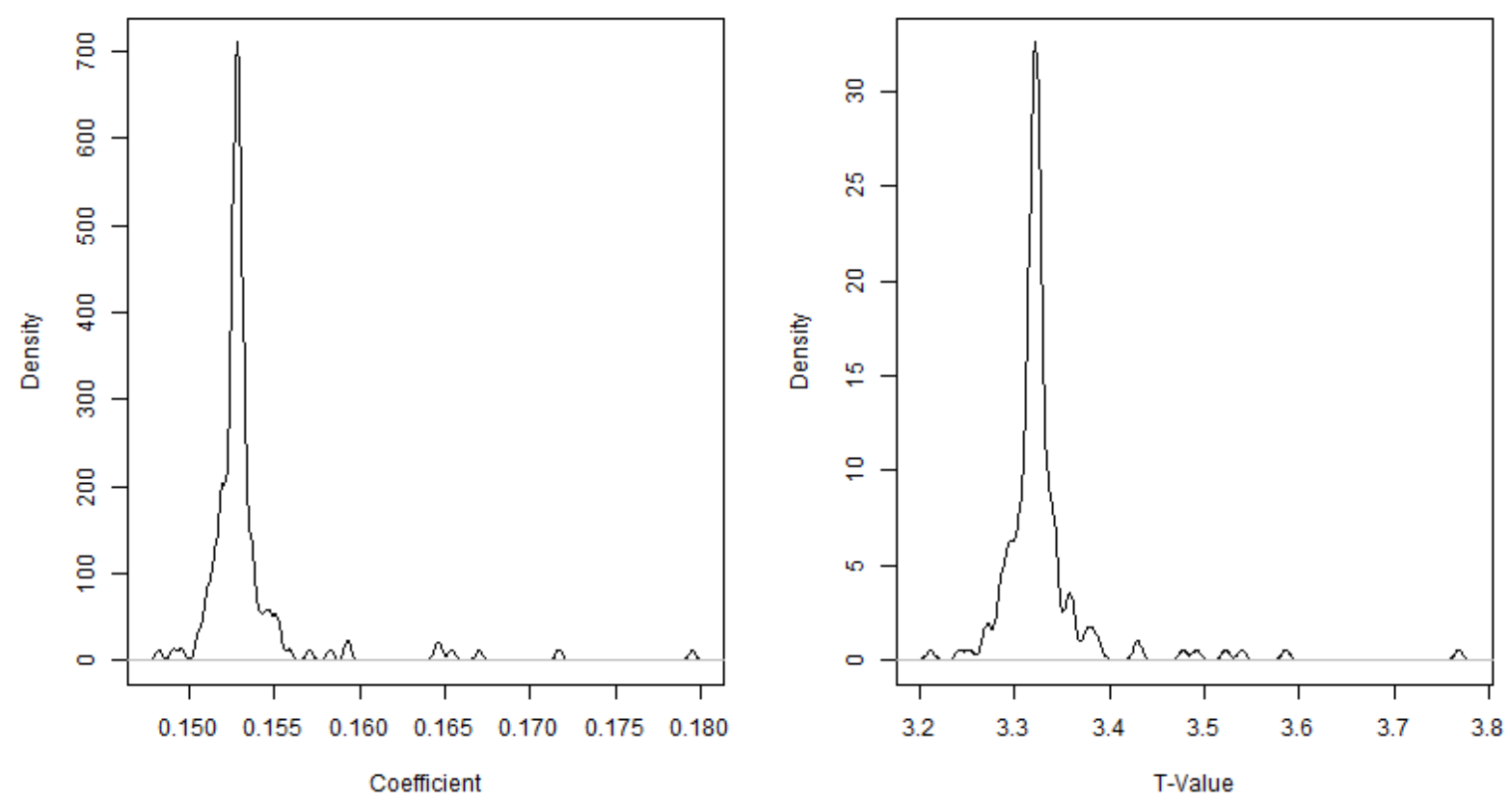

Figure A.2: Distributions of point-estimates and T-Values after a jackknife procedure of outlets: Intellectual
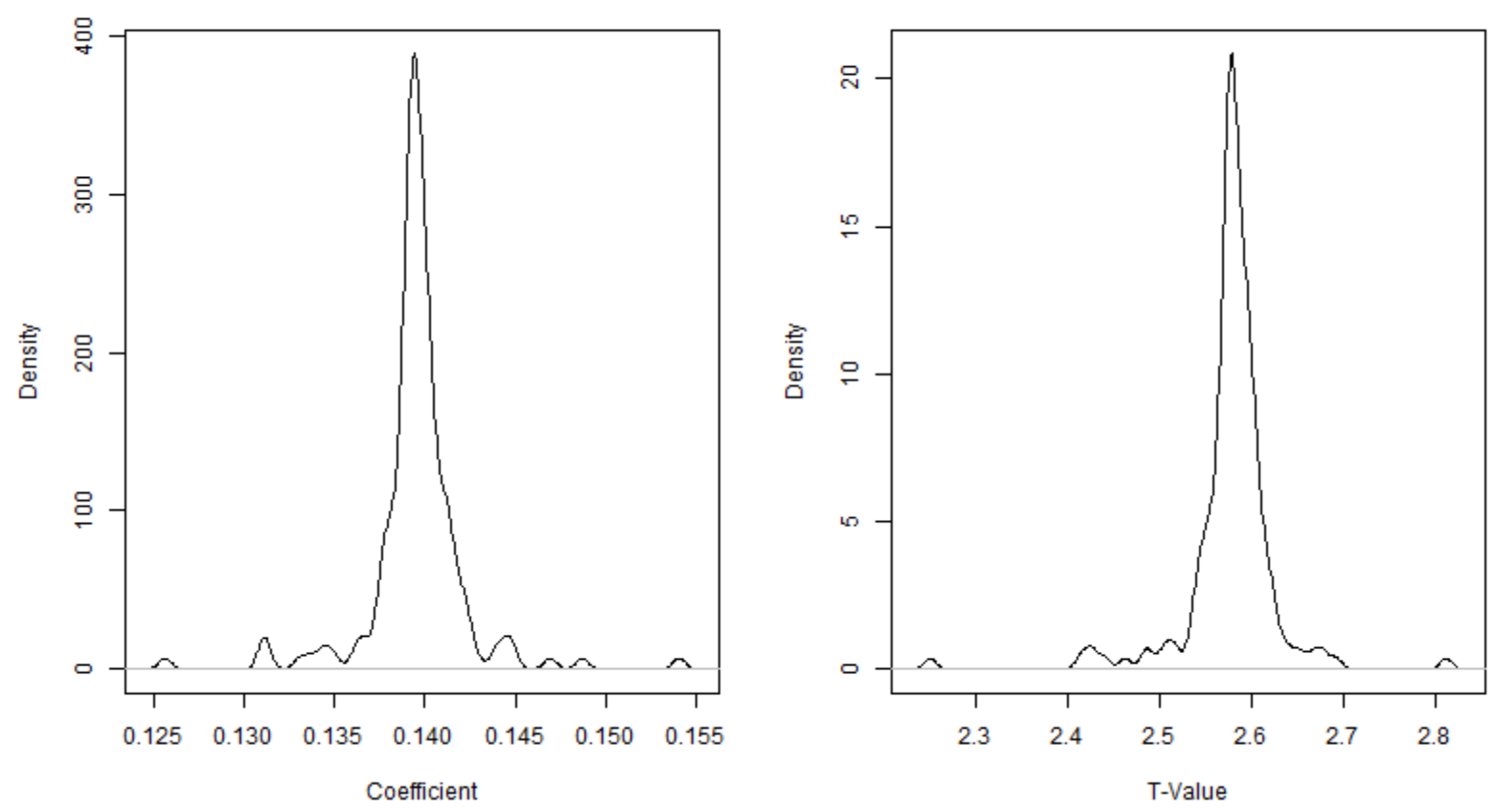
Figure A.3: Distributions of point-estimates and T-Values after a jackknife procedure of outlets: Profile features
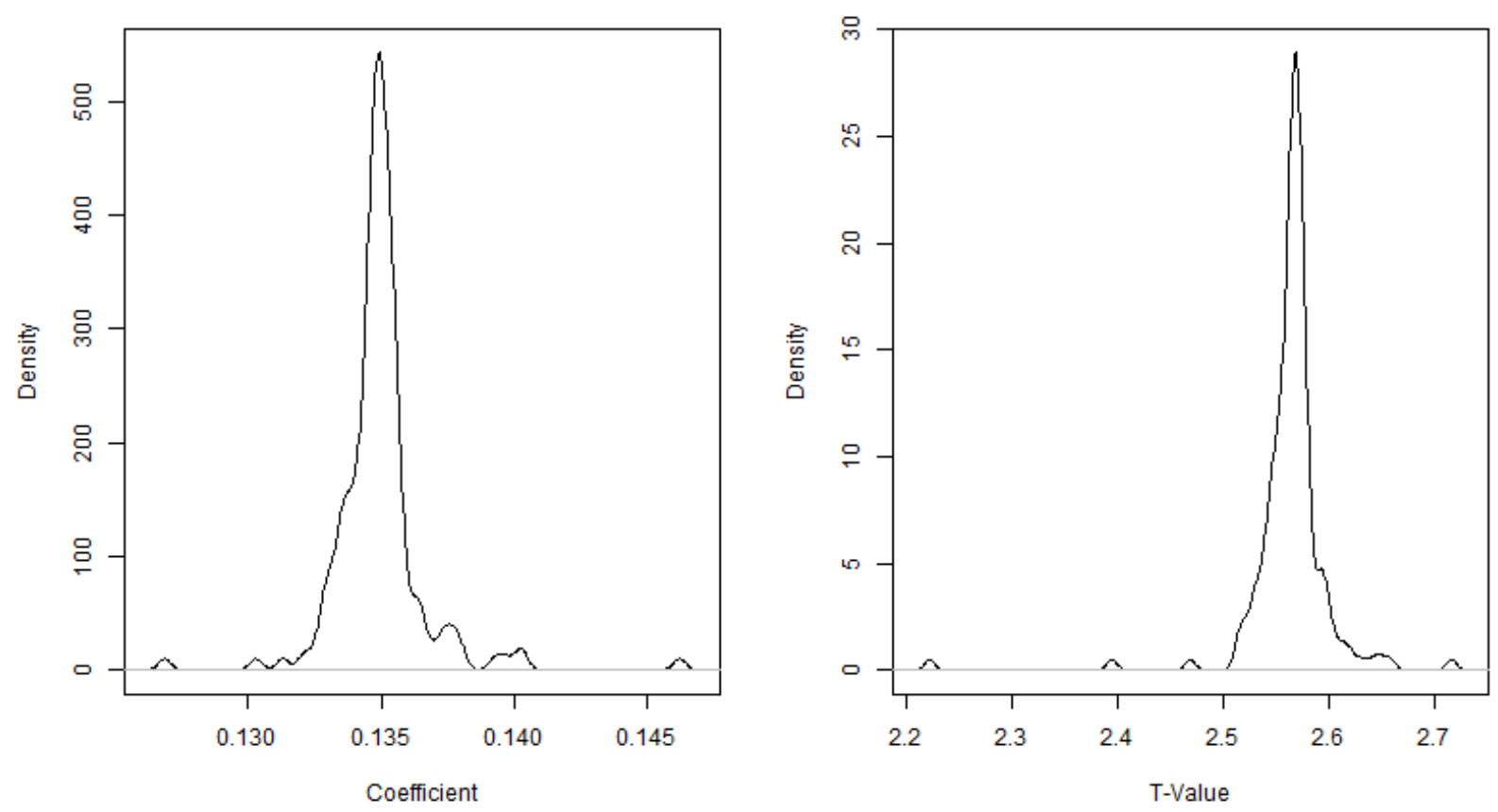

Figure A.4: Distributions of point-estimates and T-Values after a jackknife procedure of outlets: Urban-rural
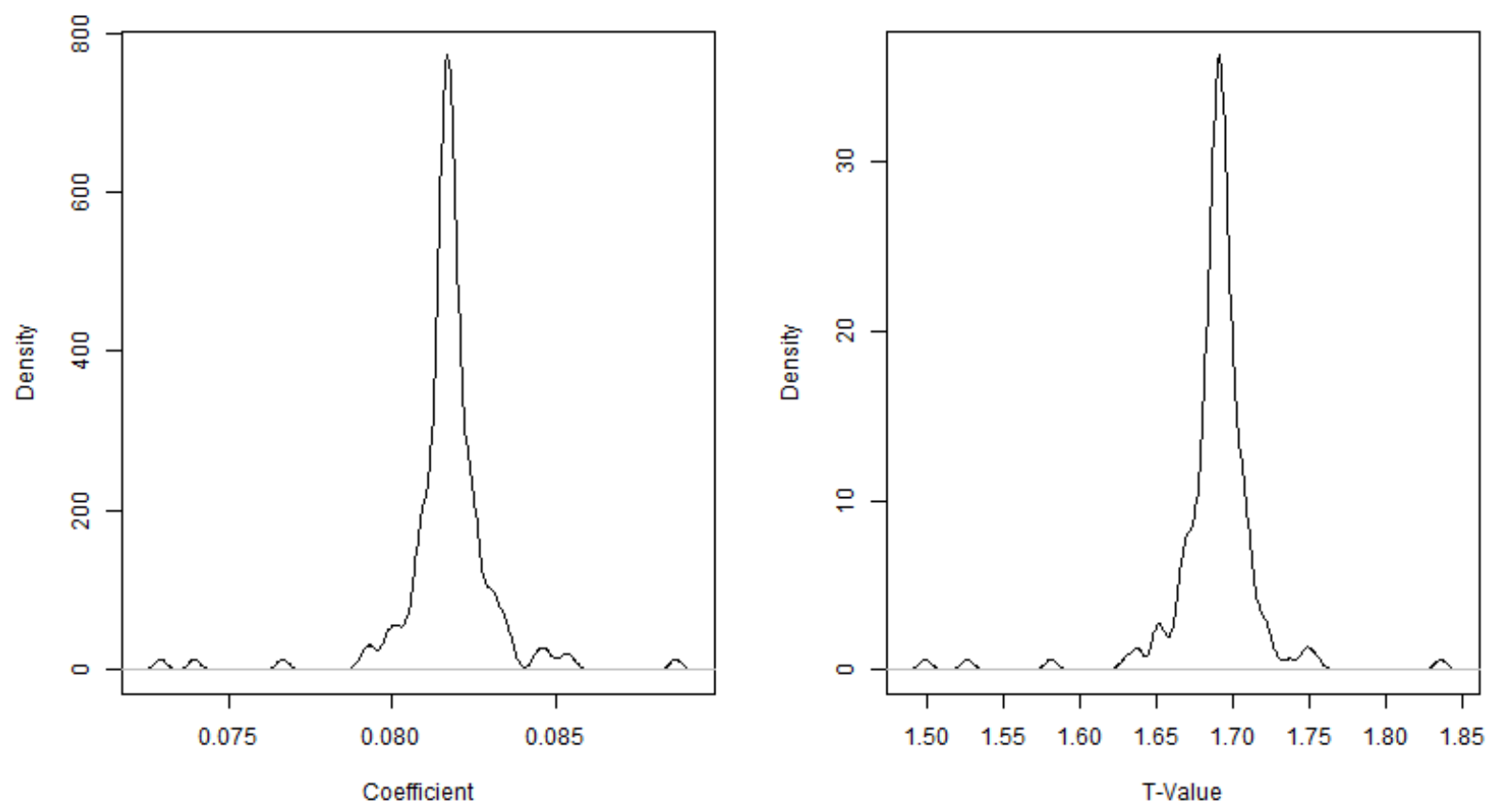
Figure A.5: Distributions of point-estimates and T-Values after a jackknife procedure of outlets: 22nd July
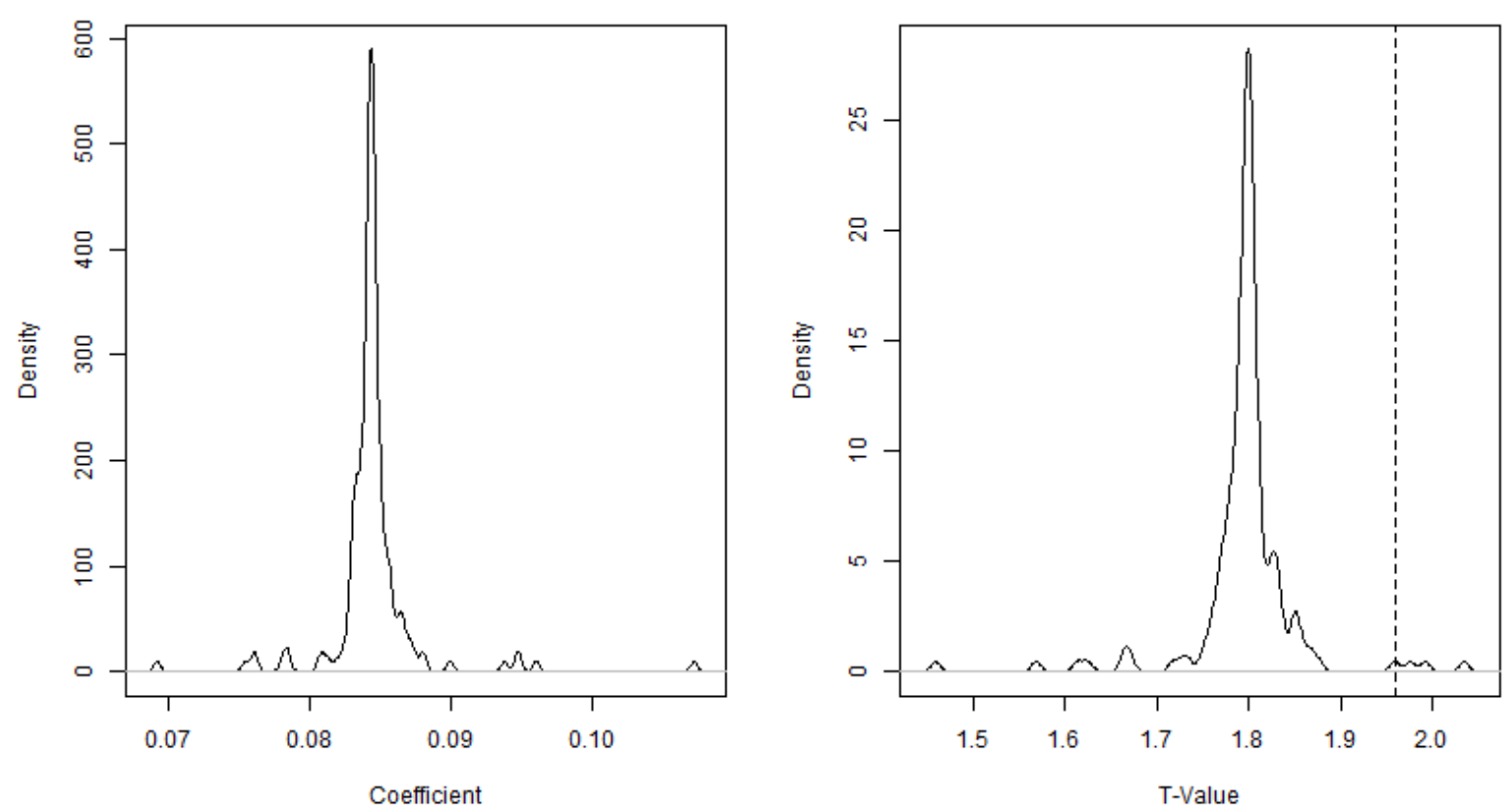

Figure A.6: Distributions of point-estimates and T-Values after a jackknife procedure of outlets: New Norwegian
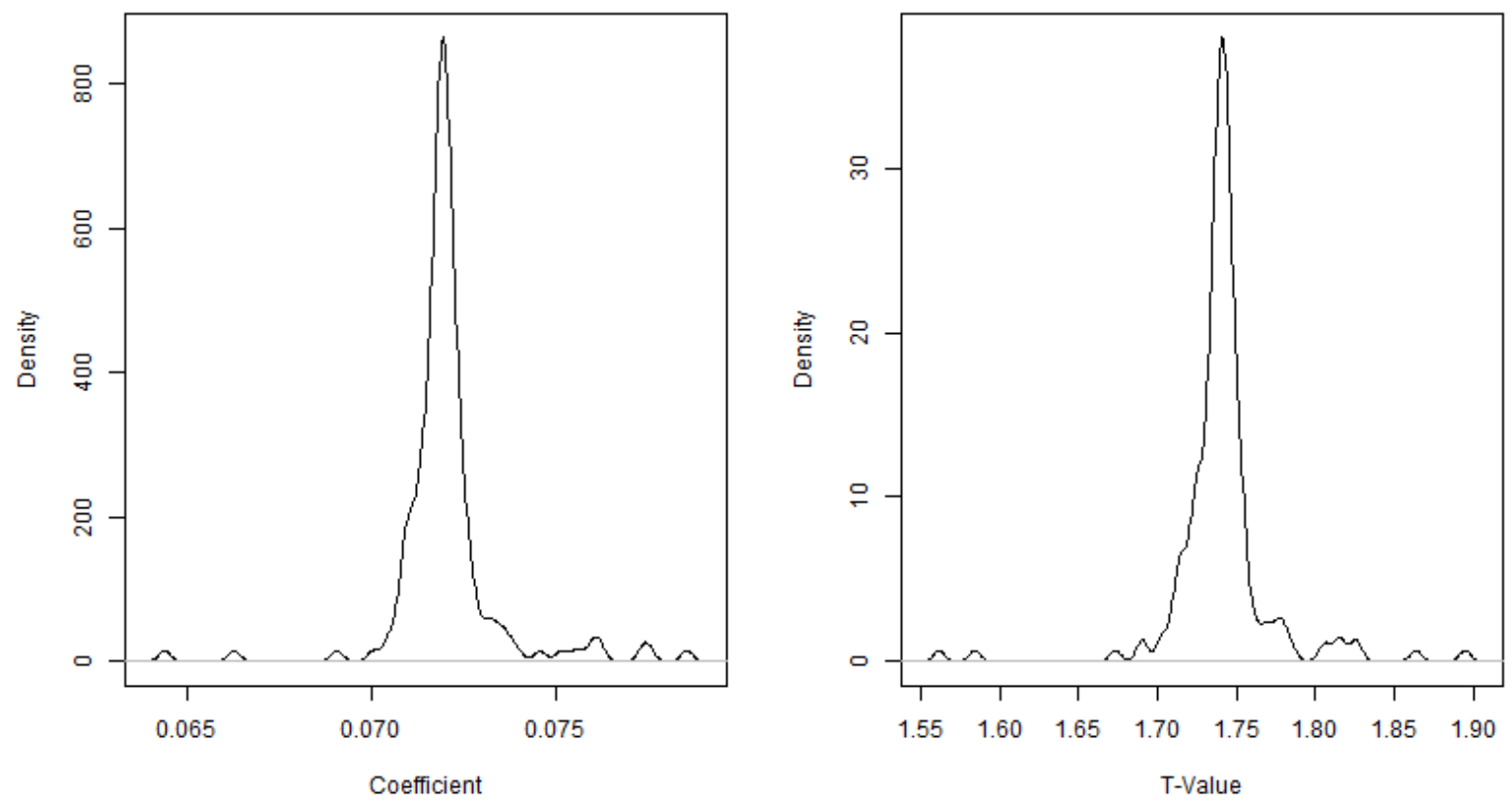

Figure A.7: Distributions of point-estimates and T-Values after a jackknife procedure of outlets: Immigration 

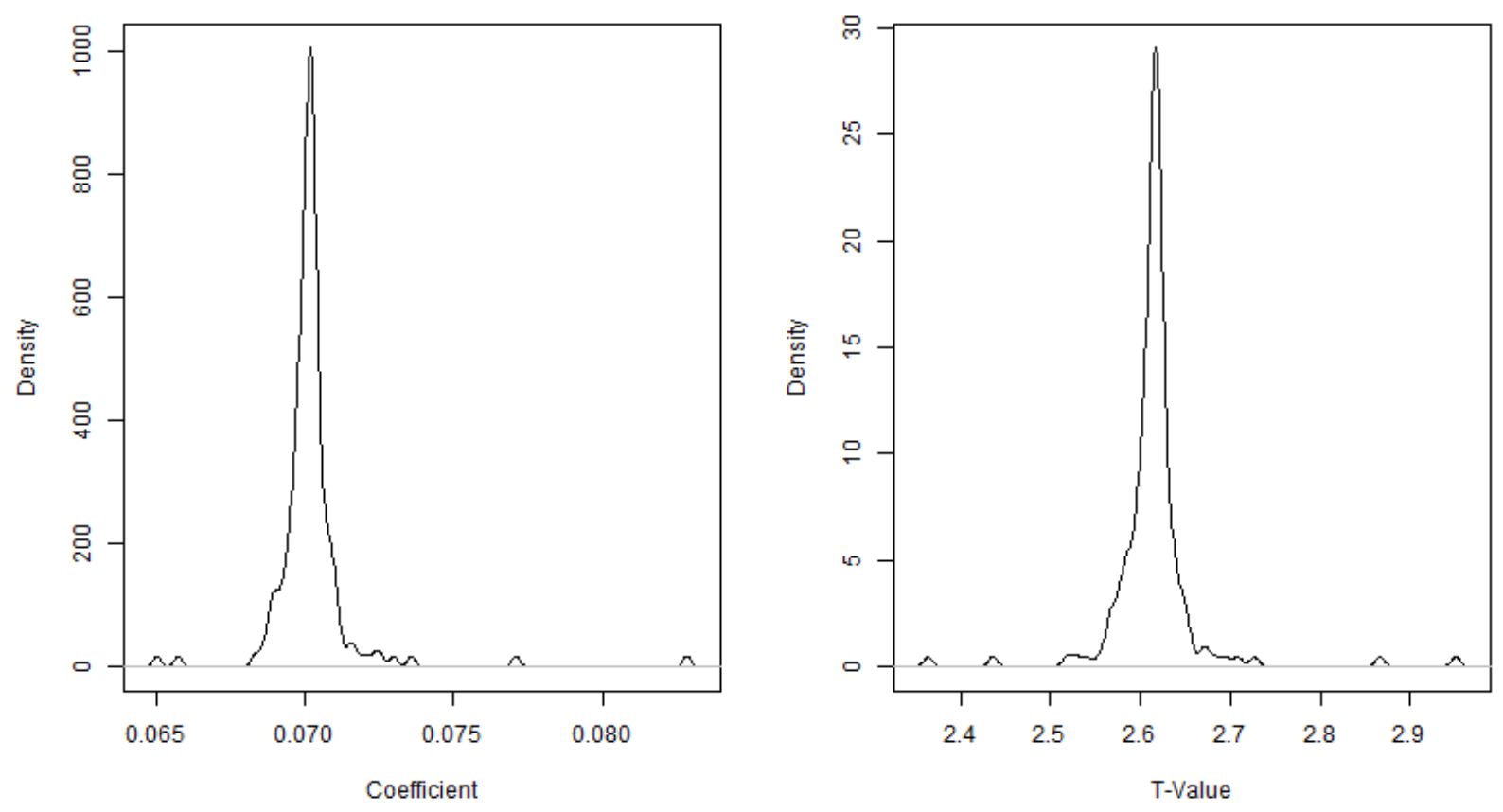

Figure A.8: Distributions of point-estimates and T-Values after a jackknife procedure of outlets: Urban Planning
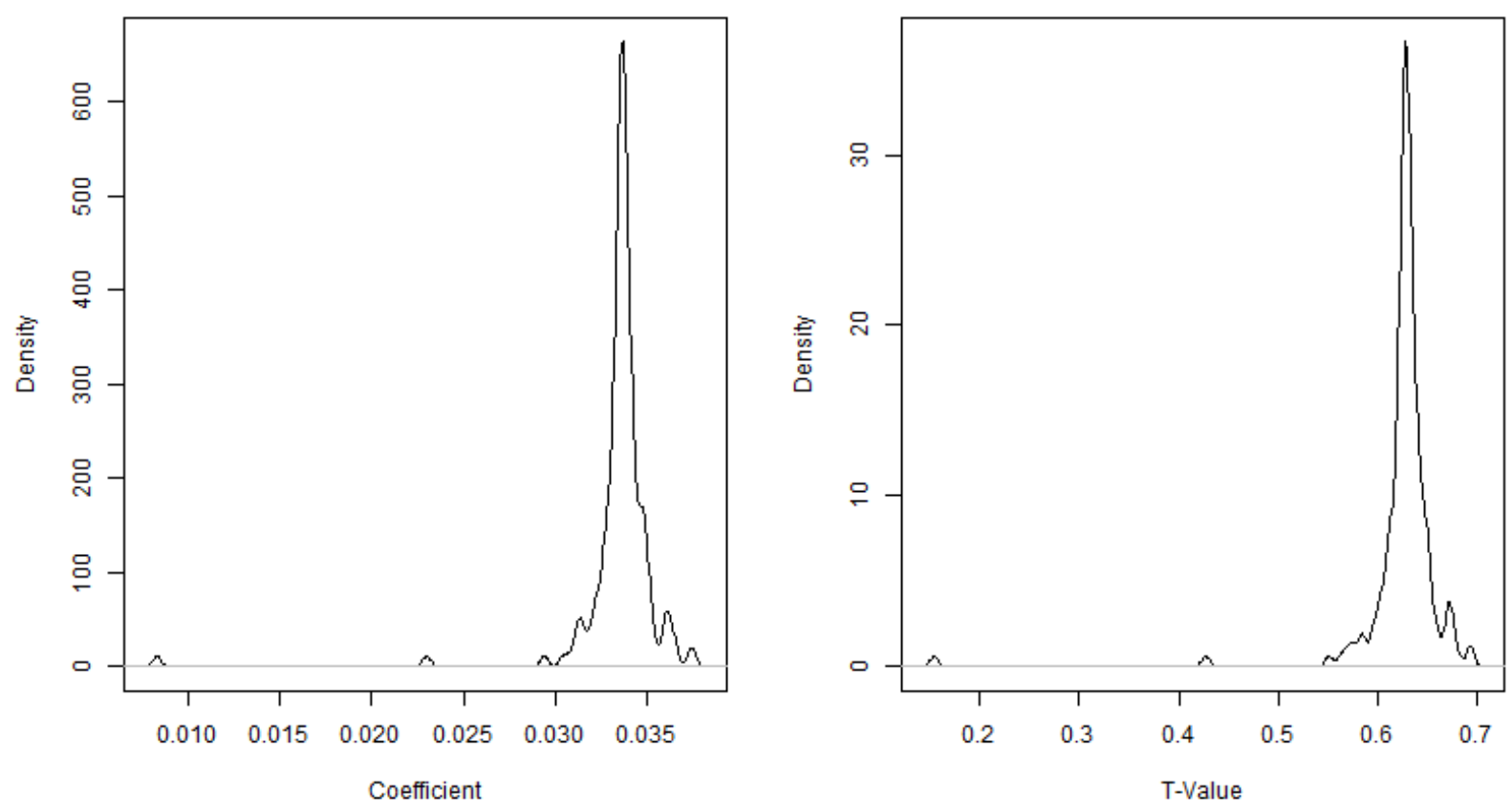

Figure A.9: Distributions of point-estimates and T-Values after a jackknife procedure of outlets: Business 

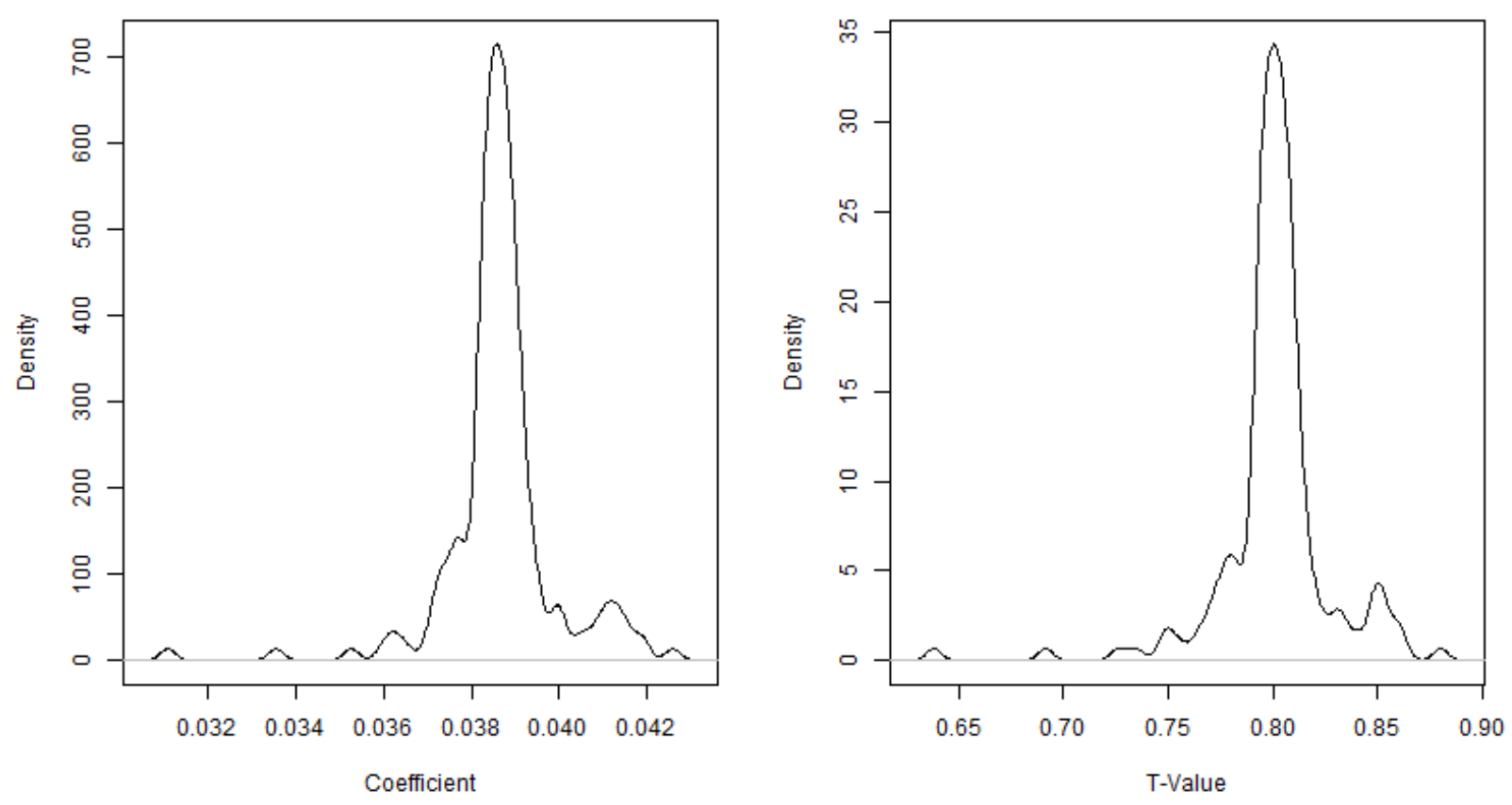

Figure A.10: Distributions of point-estimates and T-Values after a jackknife procedure of outlets: Cultural reviews
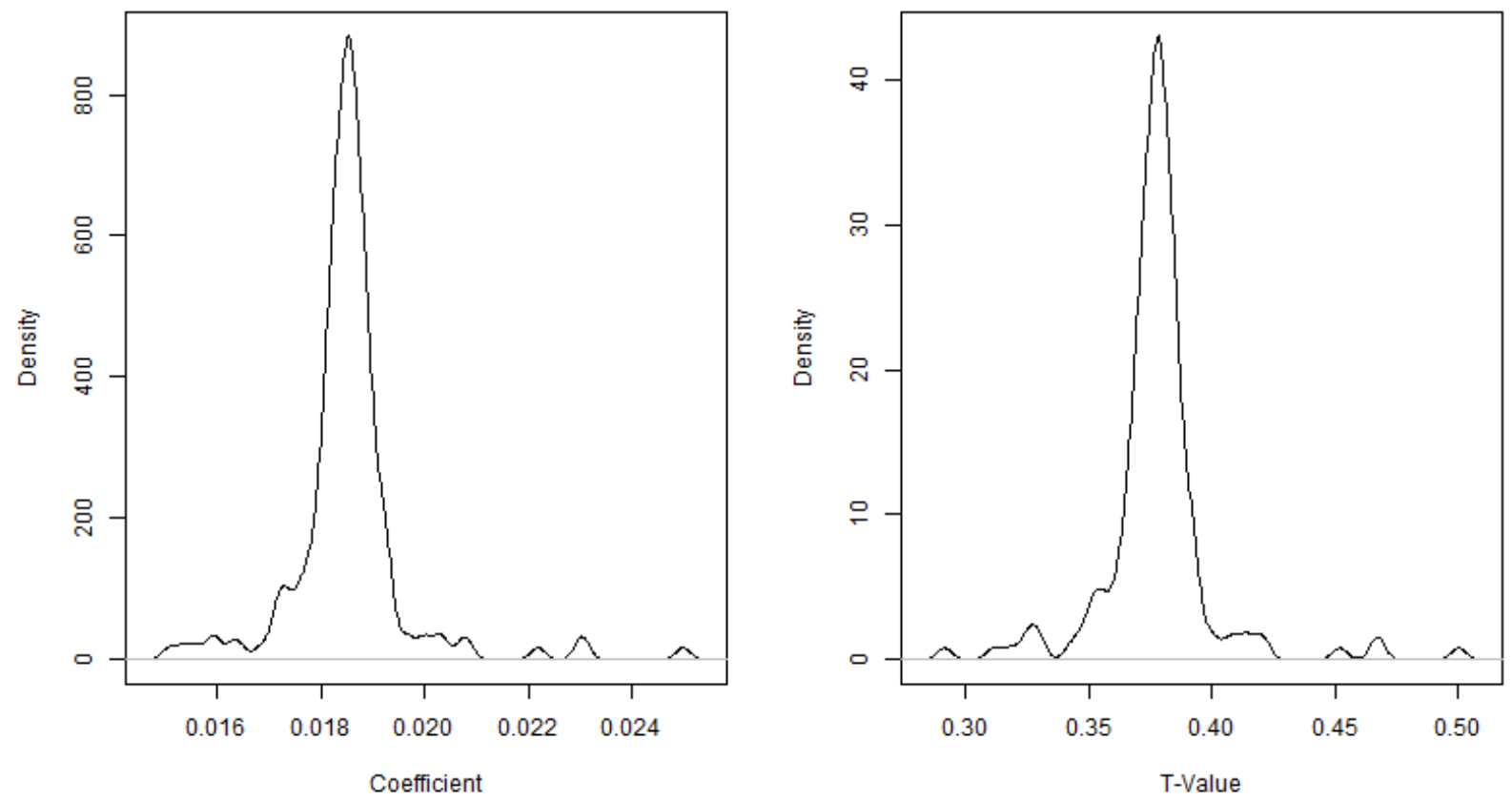

Figure A.11: Distributions of point-estimates and T-Values after a jackknife procedure of outlets: Court cases 

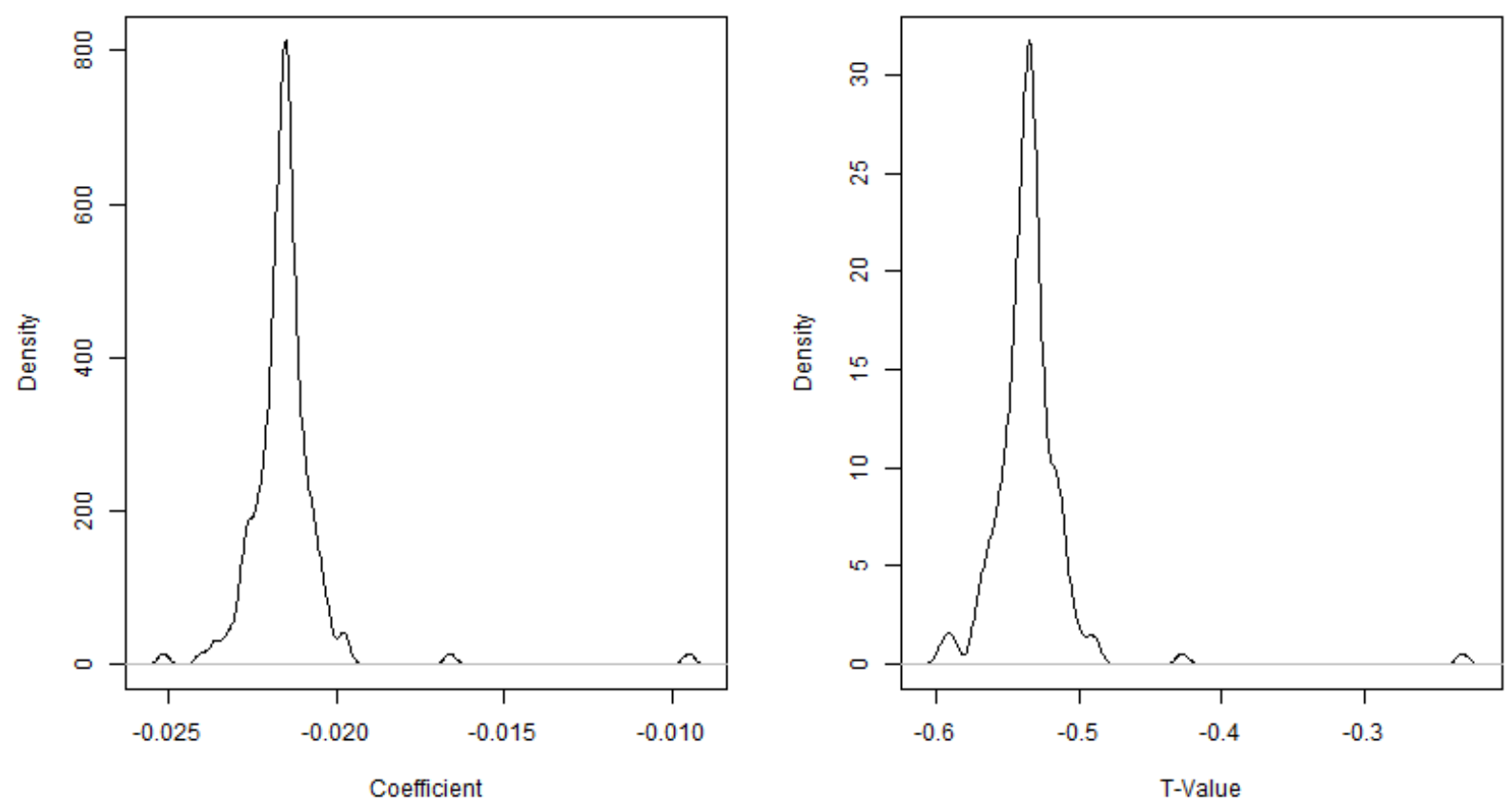

Figure A.12: Distributions of point-estimates and T-Values after a jackknife procedure of outlets: Health and technology
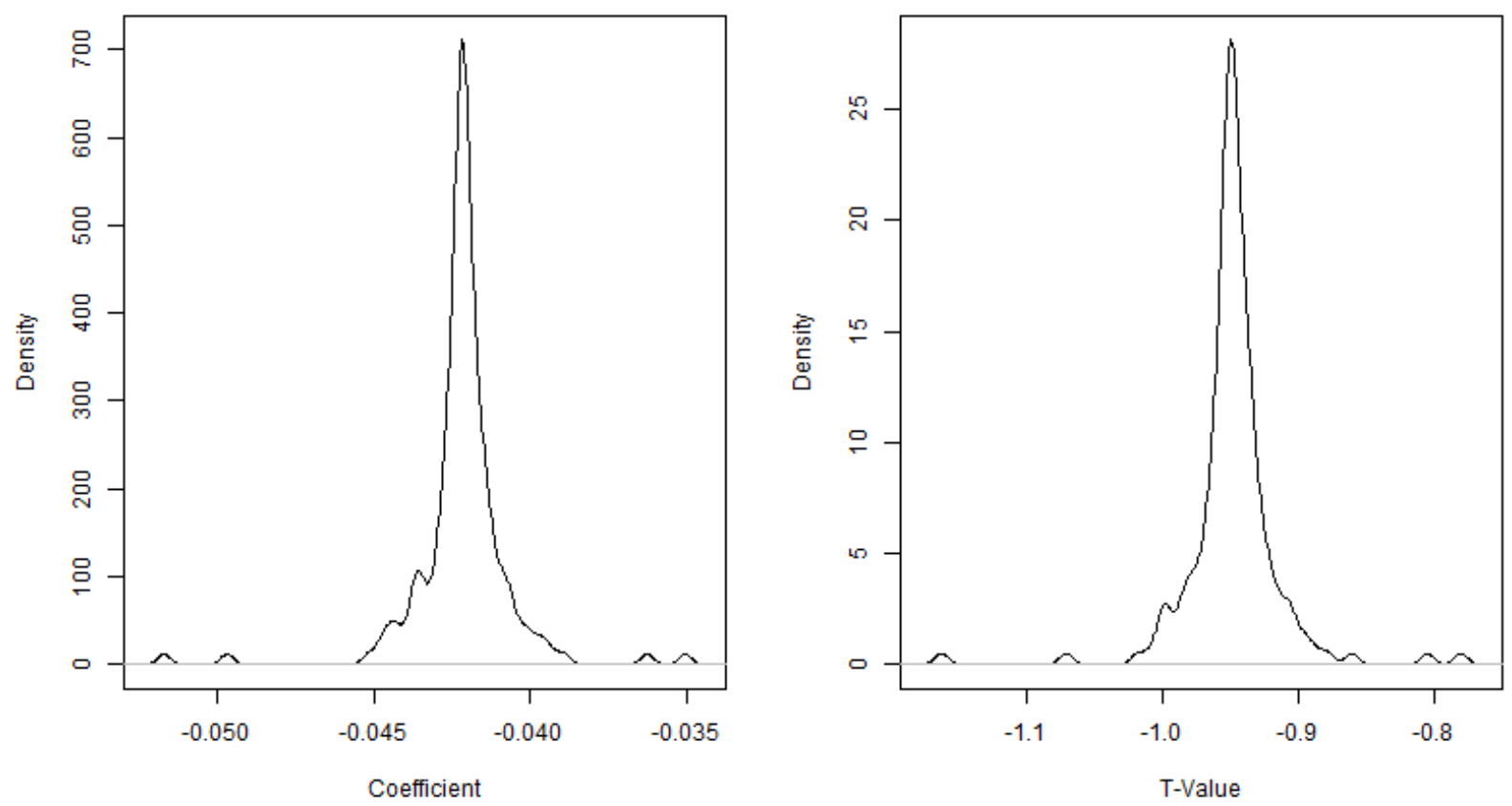

Figure A.13: Distributions of point-estimates and T-Values after a jackknife procedure of outlets: Education 

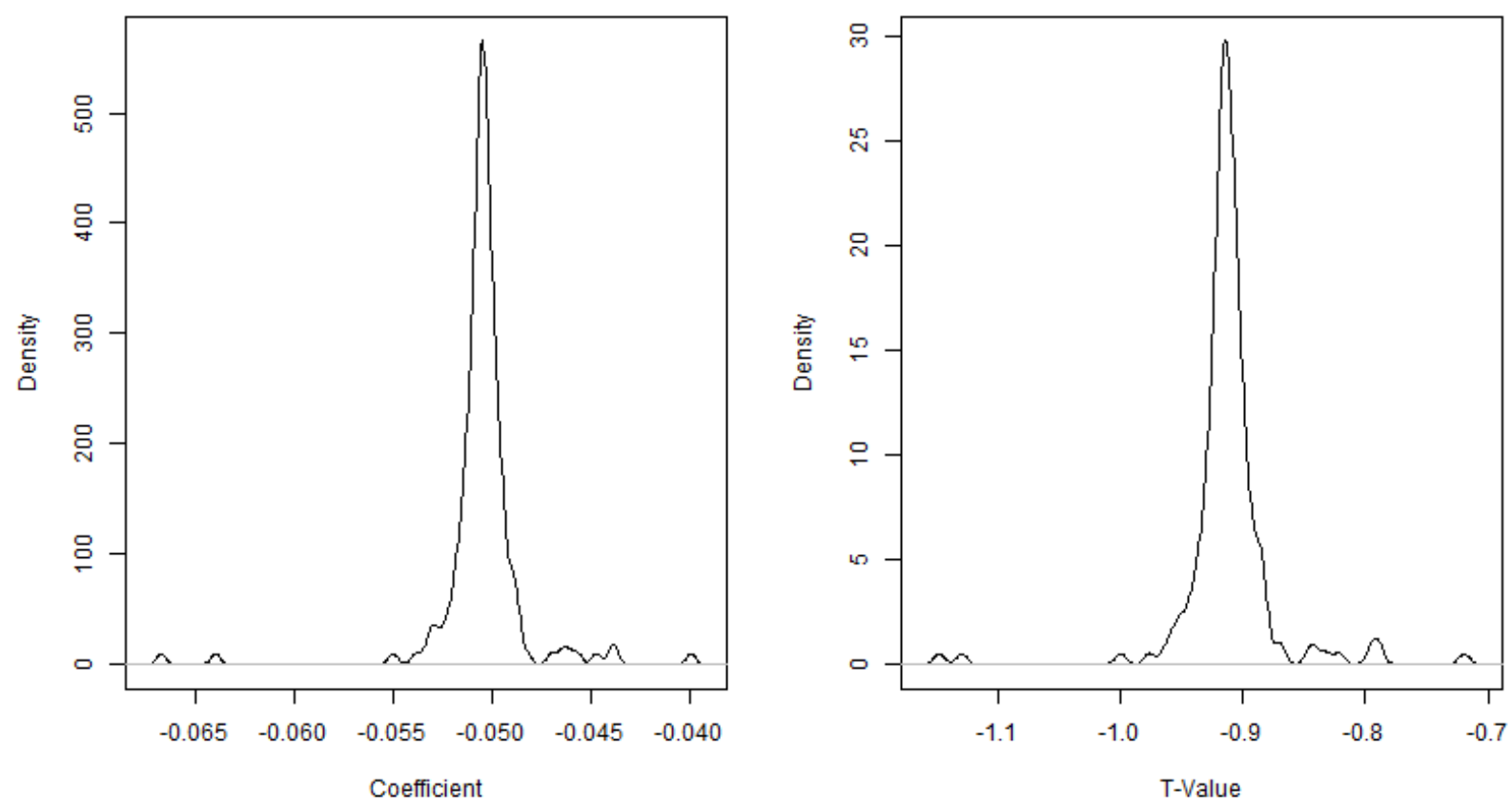

Figure A.14: Distributions of point-estimates and T-Values after a jackknife procedure of outlets: Energy policies
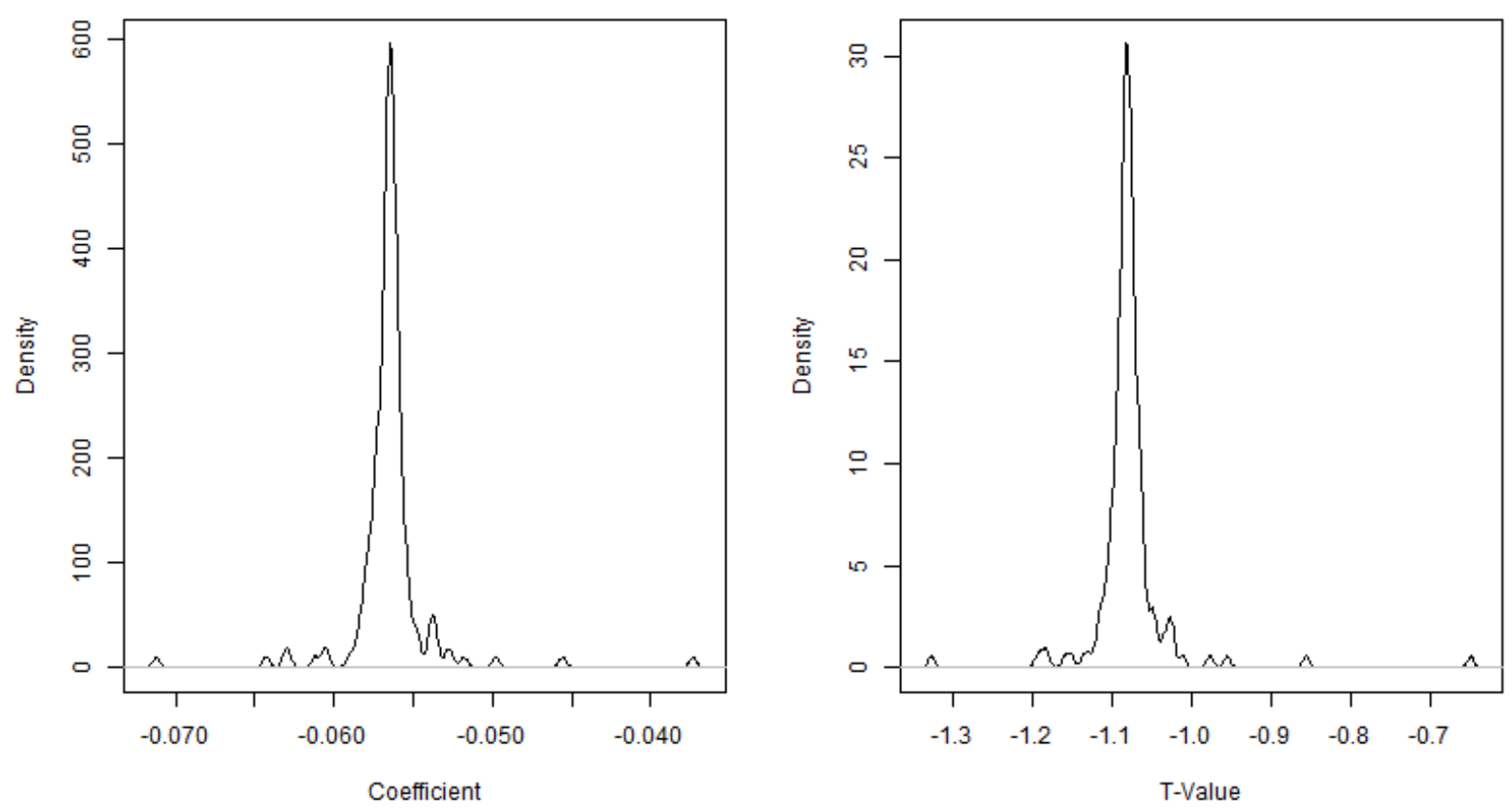

Figure A.15: Distributions of point-estimates and T-Values after a jackknife procedure of outlets: Economic analysis 

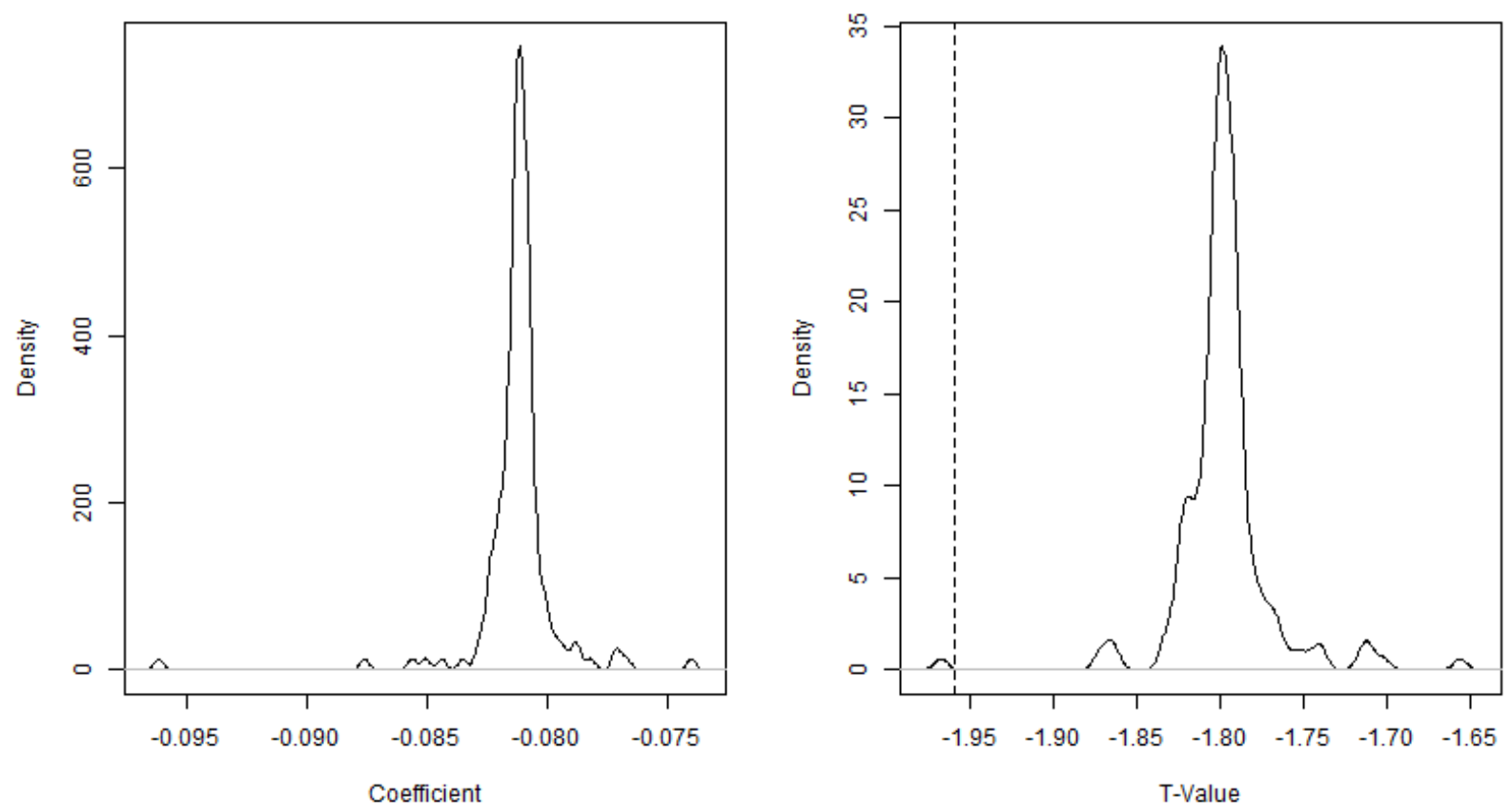

Figure A.16: Distributions of point-estimates and T-Values after a jackknife procedure of outlets: Portfolio negotiations
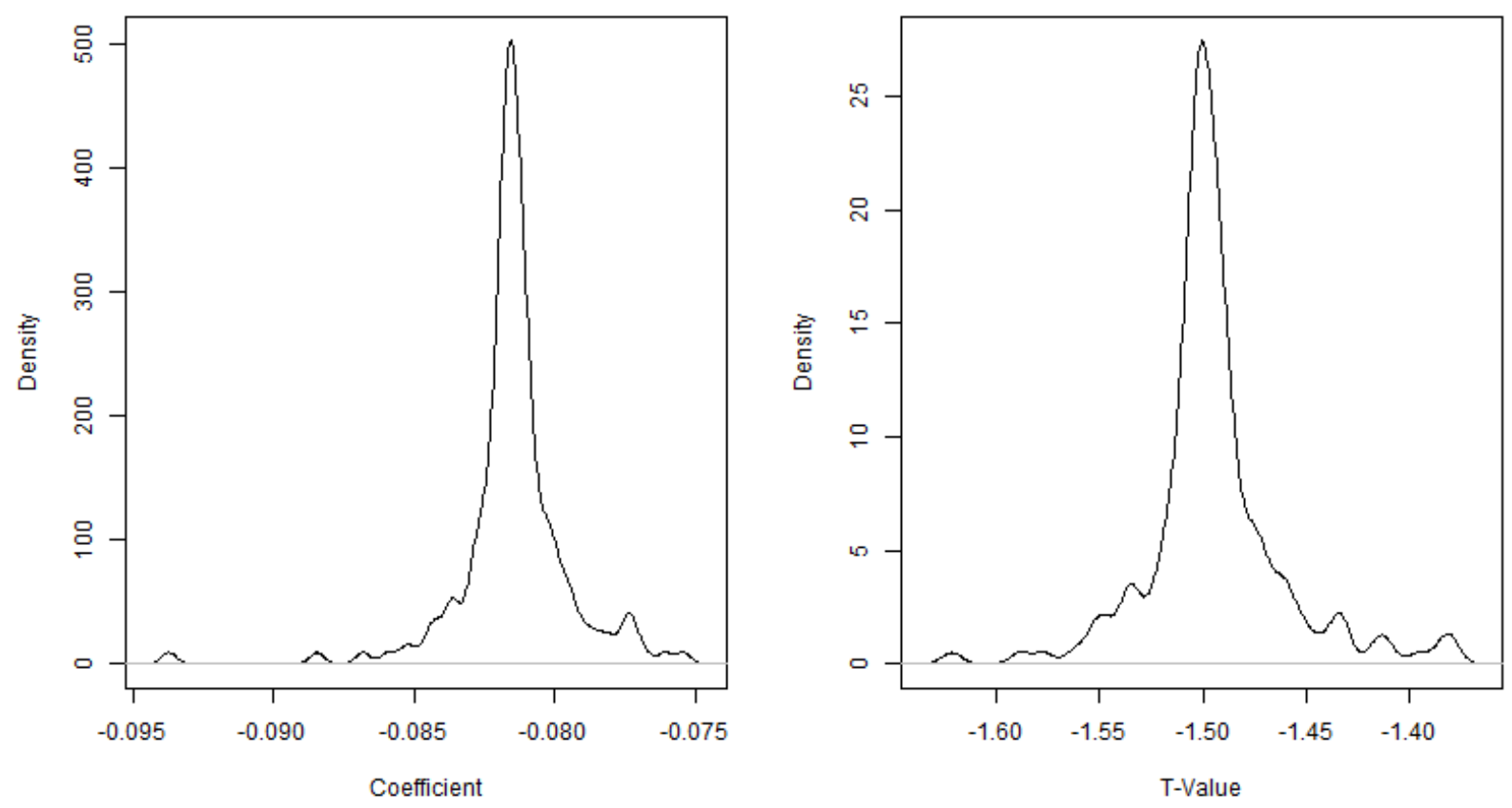

Figure A.17: Distributions of point-estimates and T-Values after a jackknife procedure of outlets: Infrastructure 

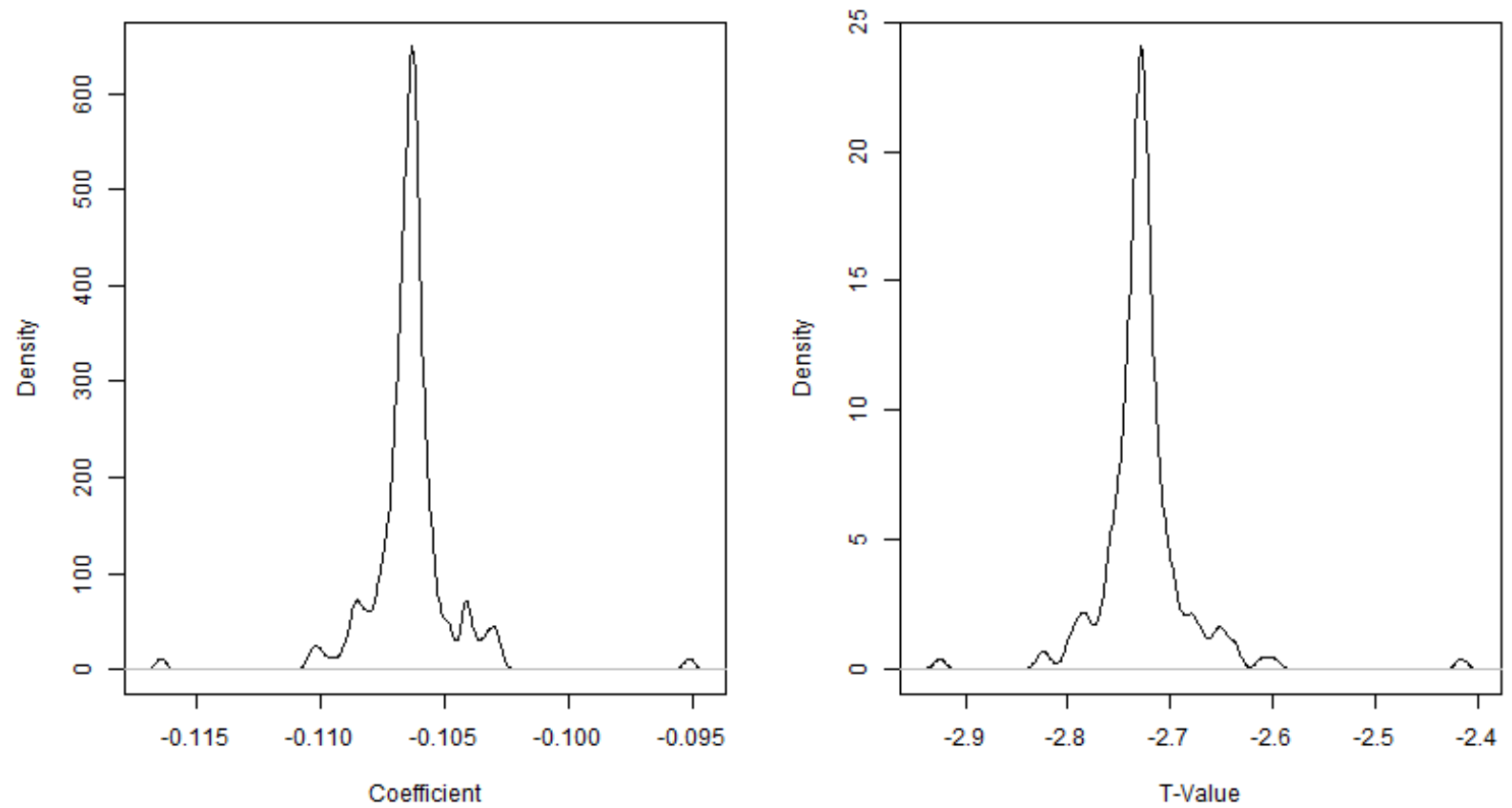

Figure A.18: Distributions of point-estimates and T-Values after a jackknife procedure of outlets: Emergencies
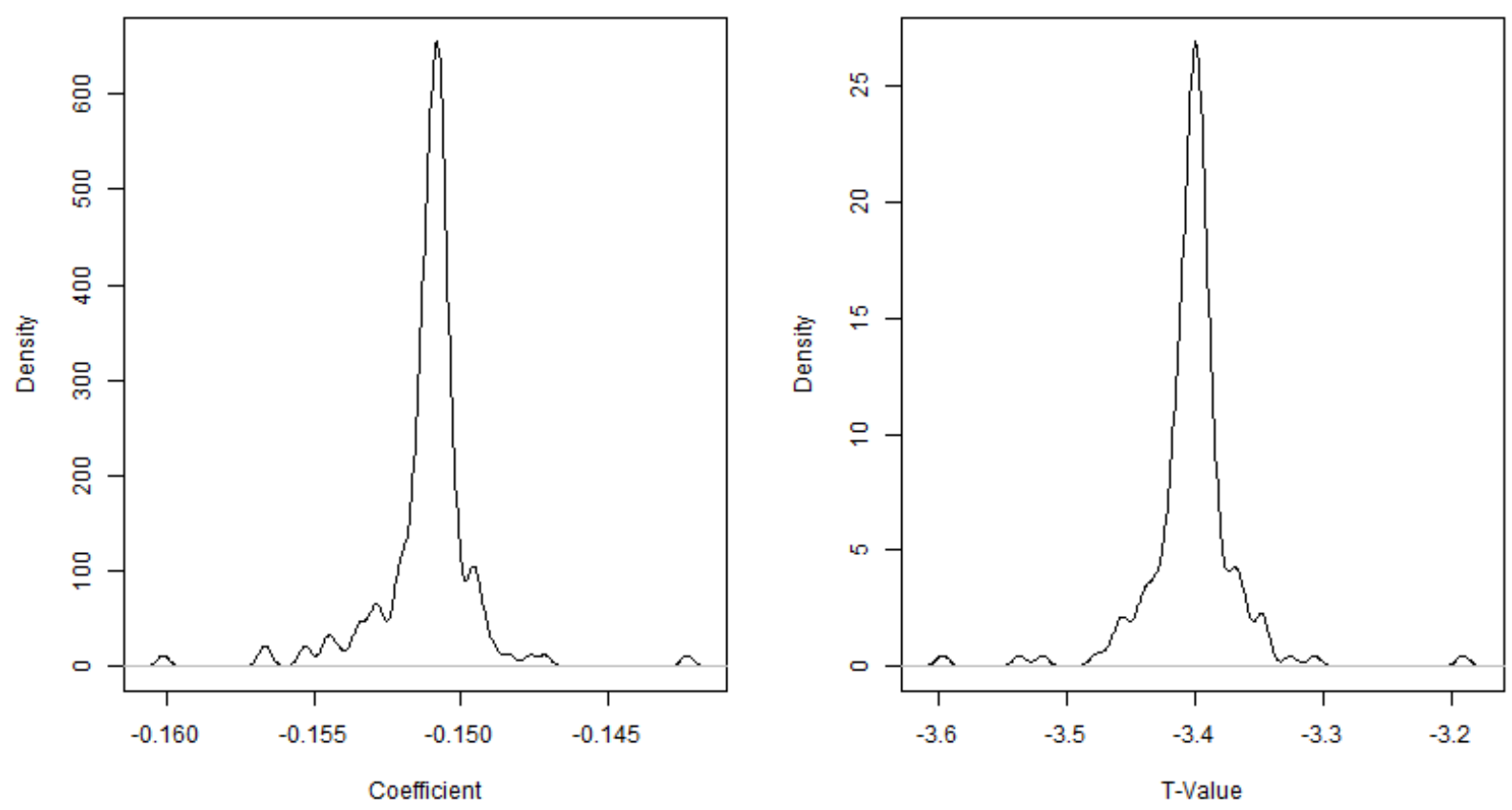

Figure A.19: Distributions of point-estimates and T-Values after a jackknife procedure of outlets: Football 


\section{A.5 Descriptive information about the different topics.}

In this section, we provide some more description of the output from the LDA. In tables A.6-A.17, we show the ten most important words for the different topics, and in figures A.20-A.44, we illustrate the distribution of the documents' probability to belong in the specific topic. We use two different estimates to define most "important" words. First, we show the ten words with the highest probability of appearing in a text, conditional on the specific topic. Second, the frex estimate instead indicates a balance between words that are frequent but also exclusive. This is arguably the best approach to identify words that distinguish between topics, since common words will have a high probability to appear in several or all of the different topics, and therefore do less to distinguish between them. We provide English translations of the original words.

Table A.6 Ten most important words in topic "22nd July" and topic "Business"

\begin{tabular}{|c|c|c|c|c|c|c|c|}
\hline \multicolumn{4}{|c|}{ 22nd July } & \multicolumn{4}{|c|}{ Business } \\
\hline \multicolumn{2}{|c|}{$\begin{array}{c}\text { Words with highest } \\
\text { probability }\end{array}$} & \multicolumn{2}{|c|}{ Words with highest frex } & \multicolumn{2}{|c|}{$\begin{array}{c}\text { Words with highest } \\
\text { probability }\end{array}$} & \multicolumn{2}{|c|}{$\begin{array}{l}\text { Words with highest } \\
\text { frex }\end{array}$} \\
\hline $\begin{array}{c}\text { Norwegian } \\
\text { original }\end{array}$ & $\begin{array}{c}\text { English } \\
\text { translation }\end{array}$ & $\begin{array}{c}\text { Norwegian } \\
\text { original }\end{array}$ & $\begin{array}{c}\text { English } \\
\text { translation }\end{array}$ & $\begin{array}{c}\text { Norwegian } \\
\text { original }\end{array}$ & $\begin{array}{c}\text { English } \\
\text { translation }\end{array}$ & $\begin{array}{c}\text { Norwegian } \\
\text { original }\end{array}$ & $\begin{array}{c}\text { English } \\
\text { translation }\end{array}$ \\
\hline breivik & Breivik & $\begin{array}{c}\text { sier } \\
\text { lippestad }\end{array}$ & $\begin{array}{c}\text { Says } \\
\text { Lippestad }\end{array}$ & orkl & Orkla & $\begin{array}{l}\text { stein erik } \\
\text { hag }\end{array}$ & $\begin{array}{c}\text { Stein Erik } \\
\text { Hagen }\end{array}$ \\
\hline auf & AUF & forsvar geir & $\begin{array}{c}\text { Defence } \\
\text { lawyer Geir }\end{array}$ & stang & Stang & $\begin{array}{l}\text { ditlev } \\
\text { simons }\end{array}$ & $\begin{array}{c}\text { Ditlev } \\
\text { Simonsen }\end{array}$ \\
\hline utøy & Utøya & $\begin{array}{l}\text { forsvar geir } \\
\text { lippestad }\end{array}$ & $\begin{array}{l}\text { Defence } \\
\text { lawyer Geir } \\
\text { Lippestad }\end{array}$ & stein erik & Stein Erik & per ditlev & Per Ditlev \\
\hline lippestad & Lippestad & hein bær & Hein Bæra & erik hag & $\begin{array}{c}\text { Erik } \\
\text { Hagen }\end{array}$ & $\begin{array}{l}\text { per ditlev } \\
\text { simons }\end{array}$ & $\begin{array}{l}\text { Per Ditlev } \\
\text { Simonsen }\end{array}$ \\
\hline behring & Behring & $\begin{array}{l}\text { breiviks } \\
\text { forsvar }\end{array}$ & $\begin{array}{c}\text { Breivik's } \\
\text { lawyer }\end{array}$ & $\begin{array}{l}\text { stein erik } \\
\text { hag }\end{array}$ & $\begin{array}{c}\text { Stein Erik } \\
\text { Hagen }\end{array}$ & canic & CANIC \\
\hline $\begin{array}{l}\text { Behring } \\
\text { breivik }\end{array}$ & $\begin{array}{l}\text { Behring } \\
\text { Breivik }\end{array}$ & vibek hein & Vibeke Hein & fabian & Fabian & treschow & Treschow \\
\hline $\begin{array}{c}\text { and } \\
\text { behring }\end{array}$ & $\begin{array}{l}\text { Anders } \\
\text { Behring }\end{array}$ & $\begin{array}{l}\text { vibek hein } \\
\text { bær }\end{array}$ & $\begin{array}{c}\text { Vibeke Hein } \\
\text { Bæra }\end{array}$ & eier & owner & $\begin{array}{l}\text { kjell ing } \\
\text { røkk }\end{array}$ & $\begin{array}{l}\text { Kjell Inge } \\
\text { Røkke }\end{array}$ \\
\hline $\begin{array}{l}\text { and } \\
\text { behring } \\
\text { breivik }\end{array}$ & $\begin{array}{l}\text { Anders } \\
\text { Behring } \\
\text { Breivik }\end{array}$ & $\begin{array}{l}\text { lippestad } \\
\text { sier }\end{array}$ & $\begin{array}{l}\text { Lippestad } \\
\text { says }\end{array}$ & $\begin{array}{l}\text { fabian } \\
\text { stang }\end{array}$ & $\begin{array}{l}\text { Fabian } \\
\text { Stang }\end{array}$ & $\begin{array}{c}\text { ordfør per } \\
\text { ditlev }\end{array}$ & $\begin{array}{l}\text { mayor Per } \\
\text { Ditlev }\end{array}$ \\
\hline geir & Geir & $\begin{array}{c}\text { synn } \\
\text { sørheim }\end{array}$ & $\begin{array}{c}\text { Synne } \\
\text { Sørheim }\end{array}$ & ordfør & mayor & orkl medi & $\begin{array}{l}\text { Orkla } \\
\text { Media }\end{array}$ \\
\hline eskil & Eskil & bej engh & Bejer Engh & aksj & stocks & $\begin{array}{c}\text { mari } \\
\text { treschow }\end{array}$ & $\begin{array}{c}\text { Marie } \\
\text { Treschow }\end{array}$ \\
\hline $\begin{array}{c}\text { geir } \\
\text { lippestad }\end{array}$ & $\begin{array}{c}\text { Geir } \\
\text { Lippestad }\end{array}$ & $\begin{array}{l}\text { breiviks } \\
\text { forsvar geir }\end{array}$ & $\begin{array}{c}\text { Beivik's } \\
\text { lawyer Geir }\end{array}$ & simons & Simonsen & sier stang & says Stang \\
\hline $\begin{array}{l}\text { eskil } \\
\text { peders }\end{array}$ & $\begin{array}{c}\text { Eskil } \\
\text { Pedersen }\end{array}$ & ing bej & Inga Bejer & styreled & $\begin{array}{l}\text { board } \\
\text { leader }\end{array}$ & $\begin{array}{l}\text { mill mari } \\
\text { treschow }\end{array}$ & $\begin{array}{c}\text { Mille } \\
\text { Marie } \\
\text { Treschow }\end{array}$ \\
\hline
\end{tabular}


Table A.7 Ten most important words in topic "Court cases" and topic "Cultural review"

\begin{tabular}{|c|c|c|c|c|c|c|c|}
\hline \multicolumn{4}{|c|}{ Court cases } & \multicolumn{4}{|c|}{ Cultural review } \\
\hline \multicolumn{2}{|c|}{$\begin{array}{l}\text { Words with highest } \\
\text { probability }\end{array}$} & \multicolumn{2}{|c|}{$\begin{array}{l}\text { Words with highest } \\
\text { frex }\end{array}$} & \multicolumn{2}{|c|}{$\begin{array}{c}\text { Words with highest } \\
\text { probability }\end{array}$} & \multicolumn{2}{|c|}{$\begin{array}{l}\text { Words with highest } \\
\text { frex }\end{array}$} \\
\hline $\begin{array}{c}\text { Norwegian } \\
\text { original }\end{array}$ & $\begin{array}{c}\text { English } \\
\text { translation }\end{array}$ & $\begin{array}{c}\text { Norwegian } \\
\text { original }\end{array}$ & $\begin{array}{c}\text { English } \\
\text { translation }\end{array}$ & $\begin{array}{c}\text { Norwegian } \\
\text { original }\end{array}$ & $\begin{array}{c}\text { English } \\
\text { translation }\end{array}$ & $\begin{array}{c}\text { Norwegian } \\
\text { original }\end{array}$ & $\begin{array}{c}\text { English } \\
\text { translation }\end{array}$ \\
\hline tingrett & $\begin{array}{l}\text { District } \\
\text { court }\end{array}$ & erling staff & Erling Staff & låt & song & $\begin{array}{c}\text { nattsendin } \\
\mathrm{g}\end{array}$ & $\begin{array}{c}\text { nightly } \\
\text { broadcast }\end{array}$ \\
\hline fengsel & prison & $\begin{array}{l}\text { tor erling } \\
\text { staff }\end{array}$ & $\begin{array}{l}\text { Tor Erling } \\
\text { Staff }\end{array}$ & kino & cinema & two and & two and \\
\hline tiltalt & indicted & $\begin{array}{l}\text { advokat } \\
\text { cato }\end{array}$ & $\begin{array}{l}\text { lawyer } \\
\text { Cato }\end{array}$ & artist & artist & distriktsny & $\begin{array}{c}\text { district } \\
\text { news }\end{array}$ \\
\hline domm & judge & $\begin{array}{c}\text { advokat } \\
\text { cato } \\
\text { schiøtz }\end{array}$ & $\begin{array}{c}\text { lawyer } \\
\text { Cato } \\
\text { Schiøtz }\end{array}$ & seri & series & $\begin{array}{l}\text { heldags } \\
\text { foto }\end{array}$ & $\begin{array}{c}\text { whole day } \\
\text { photo }\end{array}$ \\
\hline $\begin{array}{c}\text { lagmannsre } \\
\mathrm{tt}\end{array}$ & $\begin{array}{c}\text { Courts of } \\
\text { Appeal }\end{array}$ & $\begin{array}{c}\text { saksomkost } \\
\text { ning }\end{array}$ & legal costs & regi & direction & vinterkyss & $\begin{array}{l}\text { Winter's } \\
\text { Kiss }\end{array}$ \\
\hline sikt & indicted & $\begin{array}{l}\text { advokat tor } \\
\text { erling }\end{array}$ & $\begin{array}{l}\text { lawyer Tor } \\
\text { Erling }\end{array}$ & het & named & funniest & funniest \\
\hline $\mathrm{d} \varnothing \mathrm{mt}$ & sentenced & pengebevis & $\begin{array}{c}\text { money } \\
\text { evidence }\end{array}$ & musikk & music & komiseri & $\begin{array}{l}\text { comedy } \\
\text { show }\end{array}$ \\
\hline stabell & Stabell & sier staff & says Staff & of & of & hom video & $\begin{array}{l}\text { Home } \\
\text { Videos }\end{array}$ \\
\hline straff & $\begin{array}{c}\text { punishmen } \\
t\end{array}$ & $\begin{array}{l}\text { hotell } \\
\text { svært }\end{array}$ & hotel very & regiss $\varnothing r$ & director & $\begin{array}{c}\text { funniest } \\
\text { hom }\end{array}$ & $\begin{array}{c}\text { Funniest } \\
\text { Home }\end{array}$ \\
\hline ank & appeal & $\begin{array}{l}\text { sentral } \\
\text { hotel }\end{array}$ & $\begin{array}{c}\text { central } \\
\text { hotel }\end{array}$ & album & album & $\begin{array}{c}\text { funniest } \\
\text { hom video }\end{array}$ & $\begin{array}{c}\text { Funniest } \\
\text { Home } \\
\text { Videos }\end{array}$ \\
\hline drap & murder & $\begin{array}{c}\text { hotell } \\
\text { svært lav }\end{array}$ & $\begin{array}{c}\text { hotel very } \\
\text { low }\end{array}$ & programm & program & your moth & $\begin{array}{c}\text { Your } \\
\text { Mother }\end{array}$ \\
\hline treholt & Treholt & $\begin{array}{c}\text { sentral } \\
\text { hotell } \\
\text { svært }\end{array}$ & $\begin{array}{c}\text { central } \\
\text { hotel very }\end{array}$ & thom & Thom & met your & $\begin{array}{l}\text { (How I) } \\
\text { Met Your } \\
\text { (Mother) }\end{array}$ \\
\hline
\end{tabular}


Table A.8 Ten most important words in topic "Economic analyses" and topic "Education"

\begin{tabular}{|c|c|c|c|c|c|c|c|}
\hline \multicolumn{4}{|c|}{ Economic analyses } & \multicolumn{4}{|c|}{ Education } \\
\hline \multicolumn{2}{|c|}{$\begin{array}{c}\text { Words with highest } \\
\text { probability }\end{array}$} & \multicolumn{2}{|c|}{$\begin{array}{l}\text { Words with highest } \\
\text { frex }\end{array}$} & \multicolumn{2}{|c|}{$\begin{array}{c}\text { Words with highest } \\
\text { probability }\end{array}$} & \multicolumn{2}{|c|}{ Words with highest frex } \\
\hline $\begin{array}{l}\text { Norwegi } \\
\text { an } \\
\text { original }\end{array}$ & $\begin{array}{l}\text { English } \\
\text { translati } \\
\text { on } \\
\end{array}$ & $\begin{array}{c}\text { Norwegian } \\
\text { original }\end{array}$ & $\begin{array}{c}\text { English } \\
\text { translati } \\
\text { on } \\
\end{array}$ & $\begin{array}{c}\text { Norwegian } \\
\text { original }\end{array}$ & $\begin{array}{c}\text { English } \\
\text { translation }\end{array}$ & $\begin{array}{c}\text { Norwegian } \\
\text { original }\end{array}$ & $\begin{array}{c}\text { English } \\
\text { translation }\end{array}$ \\
\hline bank & bank & $\begin{array}{l}\text { sjefs } \varnothing \text { kono } \\
\text { mi } \varnothing y s t e i n\end{array}$ & $\begin{array}{c}\text { chief } \\
\text { economis } \\
\text { t } \varnothing \text { ystein }\end{array}$ & barnehag & $\begin{array}{c}\text { kindergard } \\
\text { en }\end{array}$ & $\begin{array}{c}\text { kunnskapsmin } \\
\text { ist bard }\end{array}$ & $\begin{array}{c}\text { Minister of } \\
\text { Education Bård }\end{array}$ \\
\hline rent & interest & $\begin{array}{c}\text { sjefs } \varnothing \text { kono } \\
\text { m } \varnothing \text { ystein } \\
\text { dørum }\end{array}$ & $\begin{array}{c}\text { chief } \\
\text { economis } \\
\text { t } \emptyset \text { ystein } \\
\text { Dørum }\end{array}$ & student & student & $\begin{array}{l}\text { kunnskapsmin } \\
\text { ist bard veg }\end{array}$ & $\begin{array}{c}\text { Minister of } \\
\text { Education Bård } \\
\text { Vegard }\end{array}$ \\
\hline dnb & DnB & $\begin{array}{c}\text { styringsren } \\
\mathrm{t}\end{array}$ & $\begin{array}{l}\text { key } \\
\text { policy } \\
\text { rate }\end{array}$ & utdanning & education & $\begin{array}{c}\text { sier } \\
\text { skolebyråd }\end{array}$ & $\begin{array}{l}\text { says school } \\
\text { commissioner }\end{array}$ \\
\hline marked & market & rentekutt & $\begin{array}{l}\text { interest } \\
\text { cut }\end{array}$ & fag & subject & $\begin{array}{l}\text { skolebyråd } \\
\text { annik }\end{array}$ & $\begin{array}{c}\text { school } \\
\text { commissioner } \\
\text { Anniken }\end{array}$ \\
\hline kund & customer & $\begin{array}{c}\text { sier } \\
\text { sjefs } \varnothing \text { kono } \\
\text { m }\end{array}$ & $\begin{array}{c}\text { says chief } \\
\text { economis } \\
t\end{array}$ & foreldr & parents & $\begin{array}{l}\text { skolebyråd } \\
\text { annik haugli }\end{array}$ & $\begin{array}{c}\text { school } \\
\text { commissioner } \\
\text { Anniken Haugli }\end{array}$ \\
\hline bedrift & company & $\begin{array}{c}\text { hovedinde } \\
\text { ks }\end{array}$ & $\begin{array}{c}\text { master } \\
\text { index }\end{array}$ & lærer & teacher & $\begin{array}{c}\text { oslo } \\
\text { skolebyråd }\end{array}$ & $\begin{array}{c}\text { Oslo school } \\
\text { commissioner }\end{array}$ \\
\hline$\varnothing$ konomi & economy & $\begin{array}{c}\text { sier } \\
\text { sjefs } \varnothing \text { kono } \\
\text { m } \varnothing y s t e i n\end{array}$ & $\begin{array}{l}\text { says chief } \\
\text { economis } \\
\text { t } \varnothing \text { ystein }\end{array}$ & videregå & high school & basisfag & core subject \\
\hline vekst & growth & prisfall & price fall & $\begin{array}{c}\text { departeme } \\
\text { nt }\end{array}$ & $\begin{array}{c}\text { departmen } \\
\mathrm{t}\end{array}$ & $\begin{array}{c}\text { politisk tv } \\
\text { reklam }\end{array}$ & $\begin{array}{c}\text { political TV } \\
\text { advertisement }\end{array}$ \\
\hline dørum & Dørum & fastrent & $\begin{array}{l}\text { fixed- } \\
\text { rate }\end{array}$ & utvalg & selection & sier slettholm & says Slettholm \\
\hline aksj & stocks & $\begin{array}{c}\text { rentehevin } \\
\mathrm{g}\end{array}$ & $\begin{array}{l}\text { interest } \\
\text { increase }\end{array}$ & lær & learn & $\begin{array}{l}\text { skolepolitisk } \\
\text { talsmann }\end{array}$ & $\begin{array}{l}\text { educational } \\
\text { policies } \\
\text { spokesman }\end{array}$ \\
\hline bol & housing & bind rent & $\begin{array}{c}\text { bind } \\
\text { interest }\end{array}$ & stilling & position & byrå first & $\begin{array}{l}\text { (communicatio } \\
\text { ns) agency First }\end{array}$ \\
\hline statoil & Statoil & storbank & big bank & rektor & principal & byrå first hous & $\begin{array}{c}\text { (communicatio } \\
\text { ns) agency First } \\
\text { House }\end{array}$ \\
\hline
\end{tabular}


Table A.9 Ten most important words in topic "Emergencies" and topic "Energy policies"

\begin{tabular}{|c|c|c|c|c|c|c|c|}
\hline \multicolumn{4}{|c|}{ Emergencies } & \multicolumn{4}{|c|}{ Energy policies } \\
\hline \multicolumn{2}{|c|}{$\begin{array}{l}\text { Words with highest } \\
\text { probability }\end{array}$} & \multicolumn{2}{|c|}{ Words with highest frex } & \multicolumn{2}{|c|}{$\begin{array}{c}\text { Words with highest } \\
\text { probability }\end{array}$} & \multicolumn{2}{|c|}{ Words with highest frex } \\
\hline $\begin{array}{l}\text { Norwegia } \\
n \text { original }\end{array}$ & $\begin{array}{c}\text { English } \\
\text { translatio } \\
\mathbf{n}\end{array}$ & $\begin{array}{c}\text { Norwegian } \\
\text { original }\end{array}$ & $\begin{array}{c}\text { English } \\
\text { translatio } \\
\mathbf{n}\end{array}$ & $\begin{array}{c}\text { Norwegian } \\
\text { original }\end{array}$ & $\begin{array}{c}\text { English } \\
\text { translatio } \\
\mathbf{n} \\
\end{array}$ & $\begin{array}{l}\text { Norwegian } \\
\text { original }\end{array}$ & $\begin{array}{l}\text { English } \\
\text { translation }\end{array}$ \\
\hline $\begin{array}{c}\text { fredriksta } \\
\mathrm{d}\end{array}$ & $\begin{array}{c}\text { Fredriksta } \\
\mathrm{d}\end{array}$ & operasjonsled & $\begin{array}{l}\text { operation } \\
\text { leader }\end{array}$ & kutt & cuts & skogvern & $\begin{array}{c}\text { forest } \\
\text { protection }\end{array}$ \\
\hline skad & injury & $\begin{array}{c}\text { sier } \\
\text { operasjonsled }\end{array}$ & $\begin{array}{c}\text { says the } \\
\text { operation } \\
\text { leader }\end{array}$ & reduser & reduce & $\begin{array}{l}\text { million tonn } \\
\text { co }\end{array}$ & $\begin{array}{l}\text { million ton } \\
\text { CO }\end{array}$ \\
\hline båt & boat & fikk melding & $\begin{array}{l}\text { received } \\
\text { message }\end{array}$ & budsjett & budget & $\begin{array}{c}\text { replikkordski } \\
\mathrm{ft}\end{array}$ & dialogue \\
\hline ulykk & accident & $\begin{array}{c}\text { informasjonssj } \\
\text { ef mort }\end{array}$ & $\begin{array}{c}\text { informati } \\
\text { on chief } \\
\text { Morten }\end{array}$ & energi & energy & jf document & $\begin{array}{c}\text { ref. } \\
\text { document }\end{array}$ \\
\hline natt & night & $\begin{array}{l}\text { foto karl } \\
\text { brrana }\end{array}$ & $\begin{array}{c}\text { photo Karl } \\
\text { Braana }\end{array}$ & $\begin{array}{c}\text { statsbudsje } \\
\text { tt }\end{array}$ & $\begin{array}{l}\text { governme } \\
\text { nt budget }\end{array}$ & $\begin{array}{c}\text { president } \\
\text { representan } \\
\mathrm{t}\end{array}$ & $\begin{array}{c}\text { president } \\
\text { representati } \\
\text { ve }\end{array}$ \\
\hline brann & fire & $\begin{array}{l}\text { informasjonssj } \\
\text { ef mort schau }\end{array}$ & $\begin{array}{c}\text { informati } \\
\text { on chief } \\
\text { Moren } \\
\text { Schau }\end{array}$ & utslipp & emission & $\begin{array}{l}\text { forslagsstille } \\
\text { rn men }\end{array}$ & $\begin{array}{l}\text { proposer } \\
\text { thinks }\end{array}$ \\
\hline$\varnothing$ stfold & $\varnothing$ stfold & $\begin{array}{l}\text { politi fikk } \\
\text { melding }\end{array}$ & $\begin{array}{c}\text { police } \\
\text { received } \\
\text { message }\end{array}$ & co & $\mathrm{CO}$ & $\begin{array}{c}\text { studentunio } \\
\text { n nsu }\end{array}$ & $\begin{array}{c}\text { Student } \\
\text { Union NSU }\end{array}$ \\
\hline funn & finding & sier schau & $\begin{array}{l}\text { says } \\
\text { Schau }\end{array}$ & olj & oil & $\begin{array}{c}\text { norsk } \\
\text { studentunio } \\
\text { n nsu }\end{array}$ & $\begin{array}{c}\text { Norwegian } \\
\text { Student } \\
\text { Union NSU }\end{array}$ \\
\hline dyr & animal & strømløs & $\begin{array}{c}\text { unpowere } \\
\text { d }\end{array}$ & $\emptyset \mathrm{ke}$ & increase & $\begin{array}{c}\text { norsk } \\
\text { vannkraft }\end{array}$ & $\begin{array}{l}\text { Norwegian } \\
\text { hydropower }\end{array}$ \\
\hline opplys & $\begin{array}{l}\text { informati } \\
\text { on }\end{array}$ & $\begin{array}{c}\text { operasjonsled } \\
\varnothing y \text { vind }\end{array}$ & $\begin{array}{c}\text { operation } \\
\text { leader } \\
\varnothing y v i n d \\
\end{array}$ & skatt & $\operatorname{tax}$ & $\begin{array}{c}\text { president } \\
\text { foreslå }\end{array}$ & $\begin{array}{l}\text { president } \\
\text { suggest }\end{array}$ \\
\hline vann & water & $\begin{array}{l}\text { operasjonsled } \\
\varnothing y v i n d \text { anders }\end{array}$ & $\begin{array}{c}\text { operation } \\
\text { leader } \\
\varnothing y v i n d \\
\text { Anders }\end{array}$ & næringsliv & business & ans vedtatt & $\begin{array}{c}\text { considered } \\
\text { passed }\end{array}$ \\
\hline kjørt & driven & $\begin{array}{c}\text { opplys } \\
\text { operasjons }\end{array}$ & $\begin{array}{c}\text { informs } \\
\text { operation } \\
\text { leader }\end{array}$ & avgift & toll & interpellant & interpellant \\
\hline
\end{tabular}


Table A.10 Ten most important words in topic "Football" and topic "Health and technology"

\begin{tabular}{|c|c|c|c|c|c|c|c|}
\hline \multicolumn{4}{|c|}{ Football } & \multicolumn{4}{|c|}{ Health and technology } \\
\hline \multicolumn{2}{|c|}{$\begin{array}{l}\text { Words with highest } \\
\text { probability }\end{array}$} & \multicolumn{2}{|c|}{$\begin{array}{l}\text { Words with highest } \\
\text { frex }\end{array}$} & \multicolumn{2}{|c|}{$\begin{array}{l}\text { Words with highest } \\
\text { probability }\end{array}$} & \multicolumn{2}{|c|}{ Words with highest frex } \\
\hline $\begin{array}{l}\text { Norwegia } \\
\text { n original }\end{array}$ & $\begin{array}{c}\text { English } \\
\text { translatio } \\
\mathbf{n}\end{array}$ & $\begin{array}{c}\text { Norwegian } \\
\text { original }\end{array}$ & $\begin{array}{c}\text { English } \\
\text { translatio } \\
\mathbf{n}\end{array}$ & $\begin{array}{c}\text { Norwegia } \\
\text { n original }\end{array}$ & $\begin{array}{c}\text { English } \\
\text { translatio } \\
\mathbf{n}\end{array}$ & $\begin{array}{l}\text { Norwegian } \\
\text { original }\end{array}$ & $\begin{array}{l}\text { English } \\
\text { translation }\end{array}$ \\
\hline klubb & club & åge hareid & $\begin{array}{c}\text { Åge } \\
\text { Hareide }\end{array}$ & hels & health & sprøyteromm & $\begin{array}{c}\text { safe } \\
\text { injection site }\end{array}$ \\
\hline tren & train & $\begin{array}{c}\text { landslagssj } \\
\text { ef }\end{array}$ & $\begin{array}{c}\text { national } \\
\text { coach }\end{array}$ & sykehus & hospital & metadon & methadone \\
\hline football & $\begin{array}{l}\text { Football } \\
\text { (soccer) }\end{array}$ & zenit st & Zenit St. & pasient & patient & heroinassister & $\begin{array}{c}\text { heroin } \\
\text { assisted }\end{array}$ \\
\hline vålereng & Vålerenga & $\begin{array}{c}\text { zenit st } \\
\text { petersburg }\end{array}$ & $\begin{array}{c}\text { Zenit St. } \\
\text { Petersbur } \\
\mathrm{g} \\
\end{array}$ & tjenest & service & sprøyterom & $\begin{array}{c}\text { safe } \\
\text { injection site }\end{array}$ \\
\hline spiller & player & keeper & Keeper & tilbud & offer & $\begin{array}{l}\text { heroinassister } \\
\text { behandling }\end{array}$ & $\begin{array}{c}\text { heroin } \\
\text { assisted } \\
\text { treatment }\end{array}$ \\
\hline sesong & season & midtb & mid field & eldr & elders & hels $\varnothing$ st & Health East \\
\hline spilt & played & midtstopp & $\begin{array}{c}\text { central } \\
\text { defender }\end{array}$ & $\begin{array}{c}\text { behandlin } \\
\mathrm{g}\end{array}$ & treatment & subutex & Subutex \\
\hline poeng & points & digitalsport & $\begin{array}{l}\text { digital } \\
\text { sport }\end{array}$ & leg & doctor & ammerudlund & $\begin{array}{c}\text { Ammerudlun } \\
\mathrm{d}\end{array}$ \\
\hline minutt & minute & bortekamp & $\begin{array}{l}\text { away } \\
\text { game }\end{array}$ & $\begin{array}{c}\text { informasjo } \\
\mathrm{n}\end{array}$ & $\begin{array}{c}\text { informatio } \\
\mathrm{n}\end{array}$ & kjærest eivind & $\begin{array}{l}\text { girlfriend } \\
\text { Eivind }\end{array}$ \\
\hline $\mathrm{vm}$ & $\begin{array}{l}\text { World } \\
\text { Cup }\end{array}$ & $\mathrm{mfk}$ & MFK & unders $\emptyset \mathrm{k}$ & investigate & $\begin{array}{l}\text { kjærest eivind } \\
\text { trædal }\end{array}$ & $\begin{array}{c}\text { girlfriend } \\
\text { Eivind } \\
\text { Trædal } \\
\end{array}$ \\
\hline erik hag & $\begin{array}{c}\text { Erik } \\
\text { Hagen }\end{array}$ & $\mathrm{d} \varnothing \mathrm{dball}$ & dead ball & sykehjem & $\begin{array}{l}\text { nursing } \\
\text { home }\end{array}$ & $\begin{array}{c}\text { behandlingspla } \\
\text { ss }\end{array}$ & $\begin{array}{l}\text { treatment } \\
\text { place }\end{array}$ \\
\hline rosenborg & $\begin{array}{c}\text { Rosenbor } \\
\mathrm{g}\end{array}$ & $\begin{array}{c}\text { landslagssj } \\
\text { ef åge }\end{array}$ & $\begin{array}{c}\text { national } \\
\text { coach Åge }\end{array}$ & sosial & social & eckbo frp & Eckbo FrP \\
\hline
\end{tabular}


Table A.11 Ten most important words in topic "Immigration" and topic "Infrastructure"

\begin{tabular}{|c|c|c|c|c|c|c|c|}
\hline \multicolumn{4}{|c|}{ Immigration } & \multicolumn{4}{|c|}{ Infrastructure } \\
\hline \multicolumn{2}{|c|}{$\begin{array}{l}\text { Words with highest } \\
\text { probability }\end{array}$} & \multicolumn{2}{|c|}{$\begin{array}{l}\text { Words with highest } \\
\text { frex }\end{array}$} & \multicolumn{2}{|c|}{$\begin{array}{c}\text { Words with highest } \\
\text { probability }\end{array}$} & \multicolumn{2}{|c|}{$\begin{array}{l}\text { Words with highest } \\
\text { frex }\end{array}$} \\
\hline $\begin{array}{c}\text { Norwegian } \\
\text { original }\end{array}$ & $\begin{array}{c}\text { English } \\
\text { translation }\end{array}$ & $\begin{array}{c}\text { Norwegian } \\
\text { original }\end{array}$ & $\begin{array}{c}\text { English } \\
\text { translation }\end{array}$ & $\begin{array}{c}\text { Norwegian } \\
\text { original }\end{array}$ & $\begin{array}{c}\text { English } \\
\text { translation }\end{array}$ & $\begin{array}{c}\text { Norwegian } \\
\text { original }\end{array}$ & $\begin{array}{c}\text { English } \\
\text { translation }\end{array}$ \\
\hline flyktning & refugee & afghanern & Afghanians & solvik & Solvik & sier solvik & says Solvik \\
\hline israel & Israel & athari & Athari & solvik ols & $\begin{array}{l}\text { Solvik } \\
\text { Olsen }\end{array}$ & $\begin{array}{c}\text { sier solvik } \\
\text { ols }\end{array}$ & $\begin{array}{c}\text { says Solvik } \\
\text { Olsen }\end{array}$ \\
\hline asyls $\varnothing$ ker & $\begin{array}{l}\text { asylum } \\
\text { seeker }\end{array}$ & $\begin{array}{l}\text { muslimsk } \\
\text { miljø }\end{array}$ & $\begin{array}{c}\text { muslim } \\
\text { community }\end{array}$ & ketil & Ketil & $\begin{array}{c}\text { samferdsel } \\
\text { sminist } \\
\text { torild }\end{array}$ & $\begin{array}{c}\text { Minister of } \\
\text { Transport } \\
\text { Torild }\end{array}$ \\
\hline muslim & muslim & $\begin{array}{l}\text { homofil } \\
\text { frigjøring }\end{array}$ & $\begin{array}{c}\text { gay } \\
\text { liberation }\end{array}$ & ketil solvik & Ketil Solvik & $\begin{array}{l}\text { samferdsel } \\
\text { sminist } \\
\text { torild } \\
\text { skogholm }\end{array}$ & $\begin{array}{c}\text { Minister of } \\
\text { Transport } \\
\text { Torild } \\
\text { Skogholm }\end{array}$ \\
\hline homofil & gay & returavtal & $\begin{array}{c}\text { return } \\
\text { agreement }\end{array}$ & $\begin{array}{l}\text { ketil solvik } \\
\text { ols }\end{array}$ & $\begin{array}{l}\text { Ketil Solvik } \\
\text { Olsen }\end{array}$ & $\begin{array}{c}\text { dobbeltspo } \\
r\end{array}$ & $\begin{array}{l}\text { double } \\
\text { track }\end{array}$ \\
\hline innvandrer & immigrant & zahir athari & $\begin{array}{l}\text { Zahir } \\
\text { Athari }\end{array}$ & $\begin{array}{l}\text { samferdsel } \\
\text { sminist }\end{array}$ & $\begin{array}{l}\text { Minister of } \\
\text { Transport }\end{array}$ & $\begin{array}{c}\text { sier } \\
\text { samferdsel } \\
\text { sminist } \\
\end{array}$ & $\begin{array}{c}\text { says } \\
\text { Minister of } \\
\text { Transport }\end{array}$ \\
\hline muslimsk & muslim & $\begin{array}{l}\text { frigjøring } \\
\text { Ilh }\end{array}$ & $\begin{array}{c}\text { liberation } \\
\text { LLH }\end{array}$ & vegves & $\begin{array}{l}\text { highway } \\
\text { authority }\end{array}$ & $\begin{array}{c}\text { sier } \\
\text { samferdsel } \\
\text { sminist } \\
\text { ketil }\end{array}$ & $\begin{array}{c}\text { says } \\
\text { Minister of } \\
\text { Transport } \\
\text { Ketil }\end{array}$ \\
\hline mynd & be of age & $\begin{array}{l}\text { forby } \\
\text { tigging }\end{array}$ & $\begin{array}{l}\text { prohibit } \\
\text { begging }\end{array}$ & stat vegves & $\begin{array}{c}\text { Norwegian } \\
\text { highways } \\
\text { authority }\end{array}$ & firefelt & four lane \\
\hline dørum & Dørum & $\begin{array}{l}\text { homofil } \\
\text { frigjøring } \\
\text { Ilh }\end{array}$ & $\begin{array}{c}\text { gay } \\
\text { liberation } \\
\text { LLH }\end{array}$ & $\begin{array}{c}\text { samferdsel } \\
\text { sdepartem } \\
\text { entet }\end{array}$ & $\begin{array}{l}\text { Ministry of } \\
\text { Transport }\end{array}$ & $\begin{array}{l}\text { samferdsel } \\
\text { sminist liv }\end{array}$ & $\begin{array}{c}\text { Minister of } \\
\text { Transport } \\
\text { Liv }\end{array}$ \\
\hline vold & violence & bruk hijab & use hijab & $\begin{array}{c}\text { samferdsel } \\
\text { sminist } \\
\text { ketil }\end{array}$ & $\begin{array}{c}\text { Minister of } \\
\text { Transport } \\
\text { Ketil }\end{array}$ & $\begin{array}{c}\text { samferdsel } \\
\text { sminist liv } \\
\text { sign }\end{array}$ & $\begin{array}{c}\text { Minister of } \\
\text { Transport } \\
\text { Liv Signe }\end{array}$ \\
\hline opphold & residence & chi nwosu & Chi Nwosu & $\begin{array}{c}\text { samferdsel } \\
\text { sminist } \\
\text { ketil solvik }\end{array}$ & $\begin{array}{c}\text { Minister of } \\
\text { Trasport } \\
\text { Ketil Solvik }\end{array}$ & $\begin{array}{c}\text { sier } \\
\text { samferdsel } \\
\text { sminist }\end{array}$ & $\begin{array}{c}\text { says } \\
\text { Minister of } \\
\text { Transport }\end{array}$ \\
\hline islam & islam & elvis chi & Elvis Chi & tog & train & heim hemn & $\begin{array}{l}\text { Heim } \\
\text { Hemne }\end{array}$ \\
\hline
\end{tabular}


Table A.12 Ten most important words in topic "Intellectual" and topic "National politics"

\begin{tabular}{|c|c|c|c|c|c|c|c|}
\hline \multicolumn{4}{|c|}{ Intellectual } & \multicolumn{4}{|c|}{ National politics } \\
\hline \multicolumn{2}{|c|}{$\begin{array}{c}\text { Words with highest } \\
\text { probability }\end{array}$} & \multicolumn{2}{|c|}{ Words with highest frex } & \multicolumn{2}{|c|}{$\begin{array}{l}\text { Words with highest } \\
\text { probability }\end{array}$} & \multicolumn{2}{|c|}{ Words with highest frex } \\
\hline $\begin{array}{l}\text { Norwegi } \\
\text { an } \\
\text { original }\end{array}$ & $\begin{array}{c}\text { English } \\
\text { translatio } \\
n\end{array}$ & $\begin{array}{c}\text { Norwegian } \\
\text { original }\end{array}$ & $\begin{array}{c}\text { English } \\
\text { translation }\end{array}$ & $\begin{array}{c}\text { Norwegia } \\
n \\
\text { original }\end{array}$ & $\begin{array}{c}\text { English } \\
\text { translatio } \\
n\end{array}$ & $\begin{array}{c}\text { Norwegian } \\
\text { original }\end{array}$ & $\begin{array}{c}\text { English } \\
\text { translation }\end{array}$ \\
\hline $\mathrm{b} \varnothing \mathrm{k}$ & books & ayn rand & Ayn Rand & valgkamp & $\begin{array}{l}\text { election } \\
\text { campaign }\end{array}$ & todal jenss & $\begin{array}{l}\text { Todal } \\
\text { Jenssen }\end{array}$ \\
\hline journalist & journalist & pol pot & Pol Pot & $\operatorname{siv}$ & Siv & $\begin{array}{c}\text { utjevningsman } \\
\text { dat }\end{array}$ & $\begin{array}{l}\text { extra } \\
\text { parliamenta } \\
\text { ry seat }\end{array}$ \\
\hline forfatter & author & $\begin{array}{c}\text { postmodernis } \\
\mathrm{m}\end{array}$ & $\begin{array}{c}\text { Post- } \\
\text { modernism }\end{array}$ & ern & Erna & sier bondevik & $\begin{array}{c}\text { says } \\
\text { Bondevik }\end{array}$ \\
\hline kultur & culture & råtekst & raw text & siv jens & $\begin{array}{l}\text { Siv } \\
\text { Jensen }\end{array}$ & valgforsker & $\begin{array}{c}\text { election } \\
\text { researcher }\end{array}$ \\
\hline redakt $\varnothing r$ & editor & $\begin{array}{l}\text { kulturradikali } \\
\text { sm }\end{array}$ & $\begin{array}{c}\text { cultural } \\
\text { extremism }\end{array}$ & landsm $\varnothing t$ & $\begin{array}{l}\text { national } \\
\text { meeting }\end{array}$ & partibaromet & $\begin{array}{c}\text { party } \\
\text { barometer }\end{array}$ \\
\hline forfatt & author & ekstremistan & $\begin{array}{c}\text { Ekstremista } \\
\mathrm{n} \text { (book) }\end{array}$ & borger & citizen & $\begin{array}{l}\text { partisekretær } \\
\text { martin }\end{array}$ & $\begin{array}{l}\text { Party } \\
\text { Secretary } \\
\text { Martin }\end{array}$ \\
\hline roman & novel & fvonk & $\begin{array}{l}\text { Fvonk } \\
\text { (book) }\end{array}$ & bondevik & Bondevik & $\begin{array}{l}\text { partisekretær } \\
\text { martin kolberg }\end{array}$ & $\begin{array}{c}\text { Party } \\
\text { Secretary } \\
\text { Martin } \\
\text { Kolberg }\end{array}$ \\
\hline professor & professor & brautigan & Brautigan & $\begin{array}{c}\text { statsmini } \\
\text { st }\end{array}$ & $\begin{array}{l}\text { Prime } \\
\text { Minister }\end{array}$ & høyr velger & $\begin{array}{c}\text { Conservativ } \\
\text { e voter }\end{array}$ \\
\hline forstå & $\begin{array}{l}\text { understa } \\
\text { nd }\end{array}$ & kosmopolitisk & $\begin{array}{c}\text { cosmopolita } \\
n\end{array}$ & $\begin{array}{c}\text { jen } \\
\text { stoltenbe } \\
\text { rg }\end{array}$ & $\begin{array}{c}\text { Jens } \\
\text { Stoltenbe } \\
\text { rg }\end{array}$ & $\begin{array}{c}\text { land st } \varnothing \text { rst } \\
\text { parti }\end{array}$ & $\begin{array}{l}\text { country's } \\
\text { largest } \\
\text { party }\end{array}$ \\
\hline forlag & publisher & stian Bromark & $\begin{array}{c}\text { Stian } \\
\text { Bromark }\end{array}$ & velgern & voters & sier valgforsk & $\begin{array}{c}\text { says } \\
\text { election } \\
\text { researcher }\end{array}$ \\
\hline form & form & $\begin{array}{l}\text { klassekamp } \\
\text { redaktør }\end{array}$ & $\begin{array}{l}\text { Klassekamp } \\
\text { en (paper) } \\
\text { editor }\end{array}$ & frps & Frp's & frp velgern & Frp voters \\
\hline kall & call & witoszeks & Witoszek's & $\begin{array}{c}\text { ern } \\
\text { solberg }\end{array}$ & $\begin{array}{l}\text { Erna } \\
\text { Solberg }\end{array}$ & valforsk bern & $\begin{array}{l}\text { election } \\
\text { researcher } \\
\text { Bernt }\end{array}$ \\
\hline
\end{tabular}


Table A.13 Ten most important words in topic "New Norwegian" and noise-category "Ads"

\begin{tabular}{|c|c|c|c|c|c|c|c|}
\hline \multicolumn{4}{|c|}{ New Norwegian } & \multicolumn{4}{|c|}{ Noise: Ads } \\
\hline \multicolumn{2}{|c|}{$\begin{array}{l}\text { Words with highest } \\
\text { probability }\end{array}$} & \multicolumn{2}{|c|}{$\begin{array}{l}\text { Words with highest } \\
\text { frex }\end{array}$} & \multicolumn{2}{|c|}{$\begin{array}{c}\text { Words with highest } \\
\text { probability }\end{array}$} & \multicolumn{2}{|c|}{ Words with highest frex } \\
\hline $\begin{array}{l}\text { Norwegia } \\
\text { n original }\end{array}$ & $\begin{array}{c}\text { English } \\
\text { translatio } \\
\mathbf{n} \\
\end{array}$ & $\begin{array}{l}\text { Norwegia } \\
\text { n original }\end{array}$ & $\begin{array}{c}\text { English } \\
\text { translatio } \\
\mathbf{n}\end{array}$ & $\begin{array}{c}\text { Norwegia } \\
n \\
\text { original } \\
\end{array}$ & $\begin{array}{c}\text { English } \\
\text { translatio } \\
\mathbf{n} \\
\end{array}$ & $\begin{array}{l}\text { Norwegian } \\
\text { original }\end{array}$ & $\begin{array}{c}\text { English } \\
\text { translation }\end{array}$ \\
\hline meir & more & mein & think & kvartal & quarter & oslo kontakt & Oslo contact \\
\hline gjer & do & fleir & more & konfrans & $\begin{array}{c}\text { conferenc } \\
\mathrm{e}\end{array}$ & $\begin{array}{l}\text { oslo oslo } \\
\text { kontakt }\end{array}$ & $\begin{array}{l}\text { Oslo Oslo } \\
\text { contact }\end{array}$ \\
\hline noreg & Norway & sjølv & even & ssb & SSB & $\begin{array}{l}\text { repotasjele } \\
\text { d }\end{array}$ & $\begin{array}{l}\text { news report } \\
\text { leader }\end{array}$ \\
\hline mein & think & fekk & got & novemb & November & $\begin{array}{c}\text { sentralbyrå } \\
\text { legg }\end{array}$ & $\begin{array}{l}\text { Central } \\
\text { bureau }\end{array}$ \\
\hline kjem & come & tidlegar & earlier & febr & February & $\begin{array}{c}\text { statistisk } \\
\text { sentralbyrå } \\
\text { legg }\end{array}$ & $\begin{array}{c}\text { Statistics } \\
\text { Norway puts }\end{array}$ \\
\hline fleir & more & fortel & tell & dato & date & $\begin{array}{l}\text { sentralbyrå } \\
\text { legg fram }\end{array}$ & $\begin{array}{l}\text { Central } \\
\text { bureau puts } \\
\text { forward }\end{array}$ \\
\hline sjølv & even & $\mathrm{d} \varnothing \mathrm{m}$ & example & $\begin{array}{c}\text { Oslo } \\
\text { kontakt }\end{array}$ & $\begin{array}{c}\text { Oslo } \\
\text { contact }\end{array}$ & fotodesk & Photo desk \\
\hline berr & just & politikar & politicians & inviter & invite & $\begin{array}{l}\text { kontakt } \\
\text { http }\end{array}$ & contact http \\
\hline vert & been & framleis & still & april & April & $\begin{array}{c}\text { sted } \\
\text { litteraturhu } \\
\mathrm{s} \\
\end{array}$ & $\begin{array}{c}\text { place } \\
\text { Litteraturhuse } \\
\mathrm{t} \\
\end{array}$ \\
\hline ver & be & difor & therefore & sted Oslo & place Oslo & ssb fredag & SSB Friday \\
\hline leiar & leader & ønskj & wish & janu & January & $\begin{array}{l}\text { legg fram } \\
\text { resultat }\end{array}$ & $\begin{array}{l}\text { presents } \\
\text { results }\end{array}$ \\
\hline fekk & got & følgj & result & arranger & organizing & ntb dekk & NTB covers \\
\hline
\end{tabular}


Table A.14 Ten most important words in noise-category "Cultural events" and noise-category "English"

\begin{tabular}{|c|c|c|c|c|c|c|c|}
\hline \multicolumn{4}{|c|}{ Noise: Cultural events } & \multicolumn{4}{|c|}{ Noise: English } \\
\hline \multicolumn{2}{|c|}{$\begin{array}{l}\text { Words with highest } \\
\text { probability }\end{array}$} & \multicolumn{2}{|c|}{ Words with highest frex } & \multicolumn{2}{|c|}{$\begin{array}{l}\text { Words with highest } \\
\text { probability }\end{array}$} & \multicolumn{2}{|c|}{$\begin{array}{l}\text { Words with highest } \\
\text { frex }\end{array}$} \\
\hline $\begin{array}{l}\text { Norwegia } \\
\text { n original }\end{array}$ & $\begin{array}{c}\text { English } \\
\text { translation }\end{array}$ & $\begin{array}{c}\text { Norwegian } \\
\text { original }\end{array}$ & $\begin{array}{c}\text { English } \\
\text { translatio } \\
\mathbf{n} \\
\end{array}$ & $\begin{array}{l}\text { Norwegian } \\
\text { original }\end{array}$ & $\begin{array}{c}\text { English } \\
\text { translatio } \\
\mathbf{n} \\
\end{array}$ & $\begin{array}{c}\text { Norwegian } \\
\text { original }\end{array}$ & $\begin{array}{c}\text { English } \\
\text { translatio } \\
\mathbf{n} \\
\end{array}$ \\
\hline musikk & music & storband & big band & usa & USA & $\begin{array}{c}\text { nettadress } \\
\text { url }\end{array}$ & $\begin{array}{c}\text { web aress } \\
\text { url }\end{array}$ \\
\hline utstilling & exhibition & $\mathrm{s} \varnothing \mathrm{n} \mathrm{kl}$ & $\begin{array}{l}\text { Sunday } \\
\text { clock }\end{array}$ & of & of & that the & that the \\
\hline scen & scene & bill kr & $\begin{array}{l}\text { ticker } \\
\text { kroner }\end{array}$ & president & president & $\begin{array}{c}\text { tidspunkt } \\
\text { departeme } \\
\text { nt } \\
\text { bestemm }\end{array}$ & $\begin{array}{c}\text { time } \\
\text { departme } \\
\text { nt decides }\end{array}$ \\
\hline sang & song & $\begin{array}{l}\text { carl mort } \\
\text { amunds }\end{array}$ & $\begin{array}{c}\text { Carl } \\
\text { Morten } \\
\text { Amundse } \\
n\end{array}$ & amerikansk & American & $\mathrm{cpv}$ & CPV \\
\hline festival & festival & åpent tir & $\begin{array}{l}\text { Open } \\
\text { Tuesday }\end{array}$ & in & in & $\begin{array}{l}\text { nettadress } \\
\text { url faks }\end{array}$ & $\begin{array}{c}\text { web } \\
\text { address } \\
\text { url fax }\end{array}$ \\
\hline band & band & arendal inviter & $\begin{array}{l}\text { Arendal } \\
\text { invites }\end{array}$ & russland & Russland & url faks & url fax \\
\hline konsert & concert & $\begin{array}{c}\text { telemarksgalle } \\
\text { ri }\end{array}$ & $\begin{array}{l}\text { Telemark } \\
\text { gallery }\end{array}$ & krig & war & $\begin{array}{l}\text { postnumm } \\
\text { land }\end{array}$ & $\begin{array}{l}\text { postal } \\
\text { code } \\
\text { country }\end{array}$ \\
\hline åpent & open & sier teatersjef & $\begin{array}{l}\text { says the } \\
\text { theatre } \\
\text { leader }\end{array}$ & nato & NATO & $\begin{array}{l}\text { address } \\
\text { poststed }\end{array}$ & $\begin{array}{c}\text { address } \\
\text { postal } \\
\text { area }\end{array}$ \\
\hline publikum & audience & åpent ti & open to & $f n$ & UN & $\begin{array}{c}\text { telefon } \\
\text { nettadress }\end{array}$ & $\begin{array}{c}\text { telephone } \\
\text { web } \\
\text { address }\end{array}$ \\
\hline $\begin{array}{c}\text { forestillin } \\
\mathrm{g}\end{array}$ & $\begin{array}{c}\text { performanc } \\
\mathrm{e}\end{array}$ & gaml ormel & old Ormel & kin & China & $\begin{array}{c}\text { telefon } \\
\text { nettadress } \\
\text { url }\end{array}$ & $\begin{array}{c}\text { telephone } \\
\text { web } \\
\text { address } \\
\text { url } \\
\end{array}$ \\
\hline teat & theatre & teat prins & $\begin{array}{l}\text { Theatre } \\
\text { Prinsen }\end{array}$ & obam & Obama & $\begin{array}{c}\text { poststed } \\
\text { postnumm }\end{array}$ & $\begin{array}{l}\text { postal } \\
\text { area } \\
\text { postal } \\
\text { code }\end{array}$ \\
\hline konser & concert & teat prins gat & $\begin{array}{l}\text { Theatre } \\
\text { Prinsen } \\
\text { street }\end{array}$ & $\begin{array}{l}\text { utenriksmini } \\
\text { st }\end{array}$ & $\begin{array}{l}\text { Minister } \\
\text { of Foreign } \\
\text { Affairs }\end{array}$ & $\begin{array}{l}\text { poststed } \\
\text { postnumm } \\
\text { land }\end{array}$ & $\begin{array}{l}\text { postal } \\
\text { area } \\
\text { postal } \\
\text { code } \\
\text { country }\end{array}$ \\
\hline
\end{tabular}


Table A.15 Ten most important words in noise-category "Events" and noise-category "Property exchange"

\begin{tabular}{|c|c|c|c|c|c|c|c|}
\hline \multicolumn{4}{|c|}{ Noise: Events } & \multicolumn{4}{|c|}{ Noise: Property exchange } \\
\hline \multicolumn{2}{|c|}{$\begin{array}{l}\text { Words with highest } \\
\text { probability }\end{array}$} & \multicolumn{2}{|c|}{ Words with highest frex } & \multicolumn{2}{|c|}{$\begin{array}{c}\text { Words with highest } \\
\text { probability }\end{array}$} & \multicolumn{2}{|c|}{$\begin{array}{l}\text { Words with highest } \\
\text { frex }\end{array}$} \\
\hline $\begin{array}{c}\text { Norwegian } \\
\text { original }\end{array}$ & $\begin{array}{l}\text { English } \\
\text { translation }\end{array}$ & $\begin{array}{l}\text { Norwegia } \\
\mathrm{n} \text { original }\end{array}$ & $\begin{array}{c}\text { English } \\
\text { translation }\end{array}$ & $\begin{array}{c}\text { Norwegia } \\
n \\
\text { original }\end{array}$ & $\begin{array}{l}\text { English } \\
\text { translation }\end{array}$ & $\begin{array}{l}\text { Norwegia } \\
\text { n original }\end{array}$ & $\begin{array}{l}\text { English } \\
\text { translation }\end{array}$ \\
\hline fullført & finished & $\begin{array}{l}\text { egen } \\
\text { bedrift }\end{array}$ & $\begin{array}{c}\text { own } \\
\text { company }\end{array}$ & seksjon & section & overdradd & transferred \\
\hline dramm & Drammen & $\begin{array}{l}\text { bedrift } \\
\text { fullført }\end{array}$ & $\begin{array}{l}\text { company } \\
\text { finished }\end{array}$ & overdradd & $\begin{array}{c}\text { transferre } \\
\mathrm{d}\end{array}$ & $\begin{array}{c}\text { overdrag } \\
\text { omfatt }\end{array}$ & $\begin{array}{l}\text { transfer } \\
\text { includes }\end{array}$ \\
\hline agder & Agder & $\begin{array}{l}\text { egen } \\
\text { bedrift } \\
\text { fullført }\end{array}$ & $\begin{array}{l}\text { own } \\
\text { company } \\
\text { finished }\end{array}$ & andel & portion & $\begin{array}{c}\text { salg } \\
\text { omfatt }\end{array}$ & $\begin{array}{c}\text { sale } \\
\text { includes }\end{array}$ \\
\hline bedrift & company & $\begin{array}{l}\text { krsand } \\
\text { kommun }\end{array}$ & $\begin{array}{c}\text { Kristiandsan } \\
d \\
\text { municipality }\end{array}$ & gunn & Gunn & fnr & $\begin{array}{l}\text { lease } \\
\text { number }\end{array}$ \\
\hline $\begin{array}{l}\text { kristiansan } \\
\text { d }\end{array}$ & $\begin{array}{c}\text { Kristiansan } \\
\text { d }\end{array}$ & $\begin{array}{l}\text { kommun } \\
\text { fullført }\end{array}$ & $\begin{array}{l}\text { municipality } \\
\text { finished }\end{array}$ & lars & Lars & andelsnr & $\begin{array}{l}\text { portion } \\
\text { number }\end{array}$ \\
\hline $\begin{array}{l}\text { egen } \\
\text { bedrift }\end{array}$ & $\begin{array}{c}\text { own } \\
\text { company }\end{array}$ & $\begin{array}{l}\text { krsand } \\
\text { kommun } \\
\text { fullført }\end{array}$ & $\begin{array}{c}\text { Kristiansand } \\
\text { municipality } \\
\text { finished }\end{array}$ & nils & Nils & $\begin{array}{c}\text { borettslag } \\
\text { andelsnr }\end{array}$ & $\begin{array}{c}\text { community } \\
\text { association } \\
\text { portion } \\
\text { number }\end{array}$ \\
\hline sørland & Sørlandet & $\begin{array}{l}\text { sørland } \\
\text { sykehus } \\
\text { fullført }\end{array}$ & $\begin{array}{l}\text { Sørland } \\
\text { hospital } \\
\text { finished }\end{array}$ & svein & Svein & $\begin{array}{l}\text { eiendom } \\
\text { gnr }\end{array}$ & $\begin{array}{c}\text { property } \\
\text { farm } \\
\text { number }\end{array}$ \\
\hline arendal & Arendal & $\begin{array}{l}\text { sykehus } \\
\text { fullført }\end{array}$ & $\begin{array}{l}\text { hospital } \\
\text { finished }\end{array}$ & overdrag & transfer & $\begin{array}{c}\text { stat } \\
\text { kartverk }\end{array}$ & $\begin{array}{c}\text { Norwegian } \\
\text { mapping } \\
\text { authority }\end{array}$ \\
\hline buskerud & Buskerud & aker $\mathrm{mh}$ & Aker $\mathrm{MH}$ & $\begin{array}{c}\text { overdrag } \\
\text { omfatt }\end{array}$ & $\begin{array}{l}\text { transfer } \\
\text { include }\end{array}$ & år tidl & $\begin{array}{l}\text { years } \\
\text { earlier }\end{array}$ \\
\hline $\begin{array}{l}\text { bedrift } \\
\text { fullført }\end{array}$ & $\begin{array}{l}\text { company } \\
\text { finished }\end{array}$ & oilwell & Oilwell & eiendom & property & $\begin{array}{l}\text { kild stat } \\
\text { kartverk }\end{array}$ & $\begin{array}{c}\text { Source } \\
\text { Norwegian } \\
\text { mapping } \\
\text { authority }\end{array}$ \\
\hline $\begin{array}{l}\text { egen } \\
\text { bedrift } \\
\text { fullført }\end{array}$ & $\begin{array}{c}\text { own } \\
\text { company } \\
\text { finished }\end{array}$ & $\begin{array}{l}\text { national } \\
\text { oilwell }\end{array}$ & $\begin{array}{c}\text { national } \\
\text { Oilwell }\end{array}$ & salg & sale & $\begin{array}{l}\text { kommun } \\
\text { overdrag }\end{array}$ & $\begin{array}{l}\text { municipalit } \\
\text { y transfer }\end{array}$ \\
\hline krsand & $\begin{array}{c}\text { Kristiansan } \\
\text { d }\end{array}$ & statbil & Statbil & kristian & Kristian & $\begin{array}{c}\text { kommun } \\
\text { overdrag } \\
\text { omfatt }\end{array}$ & $\begin{array}{l}\text { municipalit } \\
\text { y transfer } \\
\text { include }\end{array}$ \\
\hline
\end{tabular}


Table A.16 Ten most important words in noise-category "Sports results" and topic "Portfolio negotiations"

\begin{tabular}{|c|c|c|c|c|c|c|c|}
\hline \multicolumn{4}{|c|}{ Noise: Sports results } & \multicolumn{4}{|c|}{ Portfolio negotiations } \\
\hline \multicolumn{2}{|c|}{$\begin{array}{c}\text { Words with highest } \\
\text { probability }\end{array}$} & \multicolumn{2}{|c|}{$\begin{array}{l}\text { Words with highest } \\
\text { frex }\end{array}$} & \multicolumn{2}{|c|}{$\begin{array}{l}\text { Words with highest } \\
\text { probability }\end{array}$} & \multicolumn{2}{|c|}{$\begin{array}{l}\text { Words with highest } \\
\text { frex }\end{array}$} \\
\hline $\begin{array}{c}\text { Norwegian } \\
\text { original }\end{array}$ & \begin{tabular}{|c|} 
English \\
translation
\end{tabular} & $\begin{array}{c}\text { Norwegian } \\
\text { original }\end{array}$ & $\begin{array}{c}\text { English } \\
\text { translation }\end{array}$ & $\begin{array}{c}\text { Norwegian } \\
\text { original }\end{array}$ & $\begin{array}{c}\text { English } \\
\text { translation }\end{array}$ & $\begin{array}{c}\text { Norwegian } \\
\text { original }\end{array}$ & $\begin{array}{c}\text { English } \\
\text { translation }\end{array}$ \\
\hline il & IL & ck & CK & skei & Skei & $\begin{array}{l}\text { sier skei } \\
\text { grand }\end{array}$ & $\begin{array}{l}\text { says Skei } \\
\text { Grande }\end{array}$ \\
\hline avd & unit & noteam & note & lo & LO & venstr led & $\begin{array}{l}\text { Liberal } \\
\text { Party } \\
\text { leader }\end{array}$ \\
\hline domm & referee & rett $\mathrm{kr}$ & $\begin{array}{l}\text { correct } \\
\text { kroner }\end{array}$ & skei grand & Skei Grande & $\begin{array}{l}\text { sier venstr } \\
\quad \text { led }\end{array}$ & $\begin{array}{c}\text { says the } \\
\text { Liberal } \\
\text { Party } \\
\text { leader }\end{array}$ \\
\hline tilskuer & spectator & $\begin{array}{c}\text { omsetning } \\
\mathrm{kr}\end{array}$ & $\begin{array}{c}\text { turnover } \\
\text { kroner }\end{array}$ & trin & Trine & grand men & $\begin{array}{l}\text { Grande } \\
\text { argues }\end{array}$ \\
\hline troms $\varnothing$ & Troms $\varnothing$ & menn avd & men unit & trin skei & Trine Skei & $\begin{array}{l}\text { skei grand } \\
\text { men }\end{array}$ & $\begin{array}{l}\text { Skei } \\
\text { Grande } \\
\text { thinks }\end{array}$ \\
\hline gult & yellow & $\begin{array}{l}\text { bjørn hans } \\
\text { kolbotn }\end{array}$ & $\begin{array}{l}\text { Bjørn Hans } \\
\text { Kolbotn }\end{array}$ & $\begin{array}{l}\text { trin skei } \\
\text { grand }\end{array}$ & $\begin{array}{l}\text { Trine Skei } \\
\text { Grande }\end{array}$ & $\begin{array}{l}\text { nestled } \\
\text { trin }\end{array}$ & $\begin{array}{c}\text { vice- } \\
\text { chairman } \\
\text { Trine } \\
\end{array}$ \\
\hline sk & & bardu il & Bardu IL & hareid & Hareide & grand sier & $\begin{array}{c}\text { Grande } \\
\text { says }\end{array}$ \\
\hline gult kort & $\begin{array}{l}\text { yellow } \\
\text { card }\end{array}$ & $\begin{array}{l}\text { innstrand } \\
\text { il }\end{array}$ & $\begin{array}{c}\text { Innstrand } \\
\text { IL }\end{array}$ & nestled & vice-chairman & $\begin{array}{l}\text { nestled } \\
\text { trin skei }\end{array}$ & $\begin{array}{c}\text { vice- } \\
\text { chairman } \\
\text { Trine Skei }\end{array}$ \\
\hline if & IF & år makstid & $\begin{array}{l}\text { year max } \\
\text { time }\end{array}$ & sandberg & Sanberg & $\begin{array}{c}\text { sier } \\
\text { Tybring }\end{array}$ & $\begin{array}{c}\text { says } \\
\text { Tybring }\end{array}$ \\
\hline team & team & il sykkel & IL bicycle & vall & Valle & $\begin{array}{c}\text { sier } \\
\varnothing \text { stvold }\end{array}$ & $\begin{array}{c}\text { says } \\
\varnothing \text { stvold }\end{array}$ \\
\hline klass & class & $\begin{array}{l}\text { div men } \\
\text { avd }\end{array}$ & $\begin{array}{l}\text { division } \\
\text { men unit }\end{array}$ & venstr led & $\begin{array}{l}\text { Liberal Party } \\
\text { leader }\end{array}$ & $\begin{array}{l}\text { sier } \\
\text { tybring } \\
\text { gjedde } \\
\end{array}$ & $\begin{array}{l}\text { says } \\
\text { Tybring } \\
\text { Gjedde }\end{array}$ \\
\hline $\mathrm{km}$ & kilometers & il ski & IL Ski & sponheim & Sponheim & $\begin{array}{l}\text { skei grand } \\
\text { sier }\end{array}$ & $\begin{array}{l}\text { Skei } \\
\text { Grande } \\
\text { says }\end{array}$ \\
\hline
\end{tabular}


Table A.16 Ten most important words in topic "Profile features" and topic "Urban planning"

\begin{tabular}{|c|c|c|c|c|c|c|c|}
\hline \multicolumn{4}{|c|}{ Profile features } & \multicolumn{4}{|c|}{ Urban planning } \\
\hline \multicolumn{2}{|c|}{$\begin{array}{l}\text { Words with highest } \\
\text { probability }\end{array}$} & \multicolumn{2}{|c|}{ Words with highest frex } & \multicolumn{2}{|c|}{$\begin{array}{l}\text { Words with highest } \\
\text { probability }\end{array}$} & \multicolumn{2}{|c|}{ Words with highest frex } \\
\hline $\begin{array}{l}\text { Norwegia } \\
\text { n original }\end{array}$ & $\begin{array}{c}\text { English } \\
\text { translatio } \\
\mathbf{n} \\
\end{array}$ & $\begin{array}{c}\text { Norwegian } \\
\text { original }\end{array}$ & $\begin{array}{c}\text { English } \\
\text { translatio } \\
\mathbf{n}\end{array}$ & $\begin{array}{c}\text { Norwegia } \\
\mathbf{n} \\
\text { original } \\
\end{array}$ & $\begin{array}{c}\text { English } \\
\text { translation }\end{array}$ & $\begin{array}{c}\text { Norwegian } \\
\text { original }\end{array}$ & $\begin{array}{c}\text { English } \\
\text { translation }\end{array}$ \\
\hline venn & friend & mamm papp & mom dad & bydel & borough & bydelsutvalg & $\begin{array}{l}\text { borough } \\
\text { council }\end{array}$ \\
\hline gled & happiness & stor klem & big hug & bystyr & city council & nordr aker & $\begin{array}{c}\text { Nordre } \\
\text { Aker }\end{array}$ \\
\hline jent & girl & brynhild marit & $\begin{array}{l}\text { Brynhild } \\
\text { Marit }\end{array}$ & $\begin{array}{c}\text { oslo } \\
\text { kommun }\end{array}$ & $\begin{array}{c}\text { Oslo } \\
\text { municipalit } \\
\mathrm{y} \\
\end{array}$ & wiig bryn & Wiig Bryn \\
\hline tur & trip & $\begin{array}{l}\text { brynhild marit } \\
\text { berg }\end{array}$ & $\begin{array}{c}\text { Brynhild } \\
\text { Marit } \\
\text { Berg }\end{array}$ & ol & Olympics & $\begin{array}{c}\text { bydelsdirekt } \\
\varnothing r\end{array}$ & $\begin{array}{l}\text { borough } \\
\text { director }\end{array}$ \\
\hline mor & mother & berg møllers & $\begin{array}{c}\text { Berg } \\
\text { Møllers }\end{array}$ & lae & Lae & $\begin{array}{c}\text { sier } \\
\text { byrådsleder }\end{array}$ & $\begin{array}{c}\text { says the } \\
\text { city } \\
\text { governmen } \\
\text { t leader }\end{array}$ \\
\hline gutt & boy & $\begin{array}{l}\text { bursdagsklem } \\
\text { m }\end{array}$ & $\begin{array}{l}\text { birthday } \\
\text { hugs }\end{array}$ & bol & housing & bu led & live lead \\
\hline smil & smile & $\begin{array}{l}\text { marit berg } \\
\text { møllers }\end{array}$ & $\begin{array}{c}\text { Marit } \\
\text { Berg } \\
\text { Møllers }\end{array}$ & $\begin{array}{c}\text { byrådslede } \\
r\end{array}$ & $\begin{array}{c}\text { city } \\
\text { governme } \\
\text { nt leader }\end{array}$ & ol søknad & $\begin{array}{l}\text { Olympics } \\
\text { application }\end{array}$ \\
\hline hjem & home & best mamm & best mom & sentrum & center & anett wiig & $\begin{array}{c}\text { Anette } \\
\text { Wiig }\end{array}$ \\
\hline takk & thanks & klæm & Klæmint & erling & Erling & $\begin{array}{c}\text { anett wiig } \\
\text { bryn }\end{array}$ & $\begin{array}{c}\text { Anette } \\
\text { Wiig Bryn }\end{array}$ \\
\hline begynt & started & $\begin{array}{l}\text { verd best } \\
\text { mamm }\end{array}$ & $\begin{array}{l}\text { world's } \\
\text { best mom }\end{array}$ & munch & Munch & friluftsetat & $\begin{array}{c}\text { open air } \\
\text { departmen } \\
\mathrm{t}\end{array}$ \\
\hline fin & nice & bursdagsklem & $\begin{array}{l}\text { birthday } \\
\text { hug }\end{array}$ & tomt & plot & aker avis & Aker paper \\
\hline hjemm & home & kjemp glad & $\begin{array}{c}\text { very } \\
\text { happy }\end{array}$ & kommunal & municipal & $\begin{array}{c}\text { avis } \\
\text { groruddal }\end{array}$ & $\begin{array}{c}\text { paper } \\
\text { Groruddale } \\
\mathrm{n}\end{array}$ \\
\hline
\end{tabular}


Table A.17 Ten most important words in topic "Urban-rural"

\begin{tabular}{|c|c|c|c|}
\hline \multicolumn{4}{|c|}{ Urban-rural } \\
\hline Words with highest probability & \multicolumn{2}{c|}{ Words with highest frex } \\
\hline Norwegian original & English translation & Norwegian original & English translation \\
\hline mat & food & svanemerk & The Swan (Official Nordic Ecolabel) \\
\hline bønd & farmers & miljømerking & ecolabelling \\
\hline butikk & store & melkekvot & milk quota \\
\hline landbruk & agriculture & sier bjørk & says Bjørk \\
\hline sylvi & Sylvi & the pirate bay & milk farmers \\
\hline sylvi listhaug & Sylvi Listhaug & milkebønd & Norwegian agriculture \\
\hline produkt & product & norsk jordbruk & degree of self-sufficiency \\
\hline bond & farmer & selvforsyningsgrad & increase food production \\
\hline bondelag & Farmers association & $\varnothing$ ke matproduksjon & farmers must \\
\hline landbruks & agruclture & bønd må & some farmers \\
\hline var & deputy & enkelt bond & barmers Association leader \\
\hline landbruksminist & Minister of Agriculture & bondelagsled &
\end{tabular}




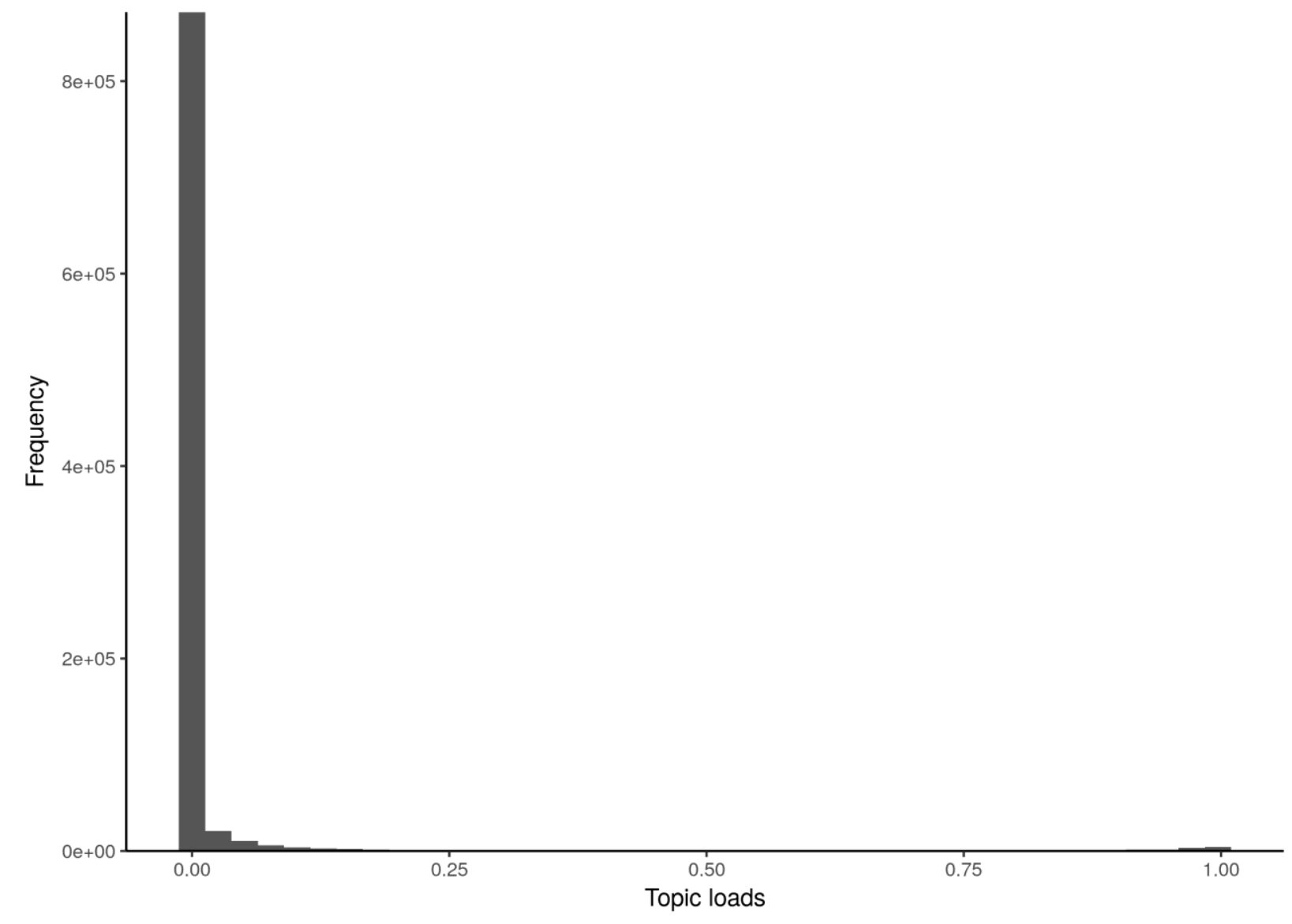

Figure A.20: Histogram of the document loads in Topic "22nd July" 


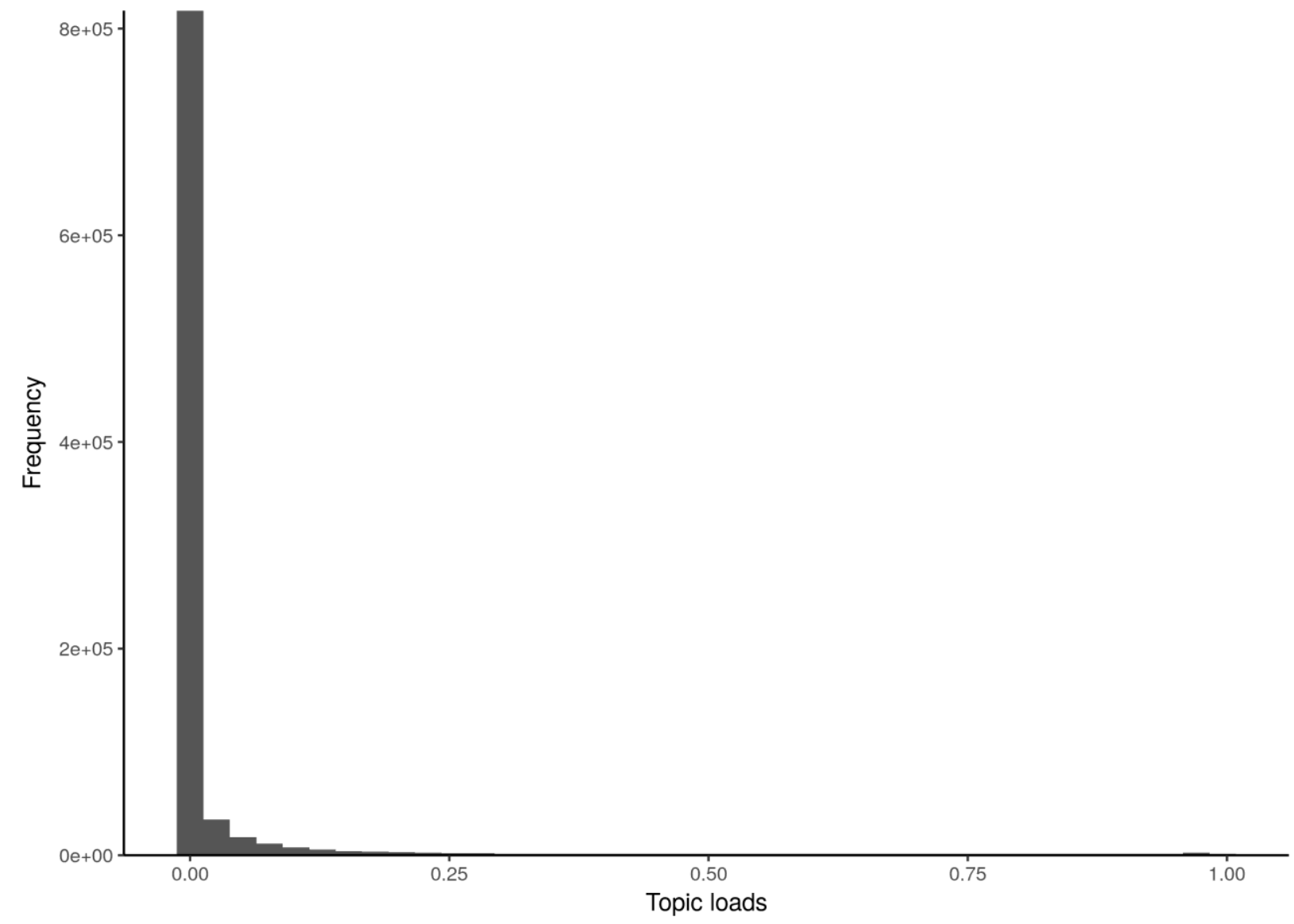

Figure A.21: Histogram of the document loads in topic "Business" 


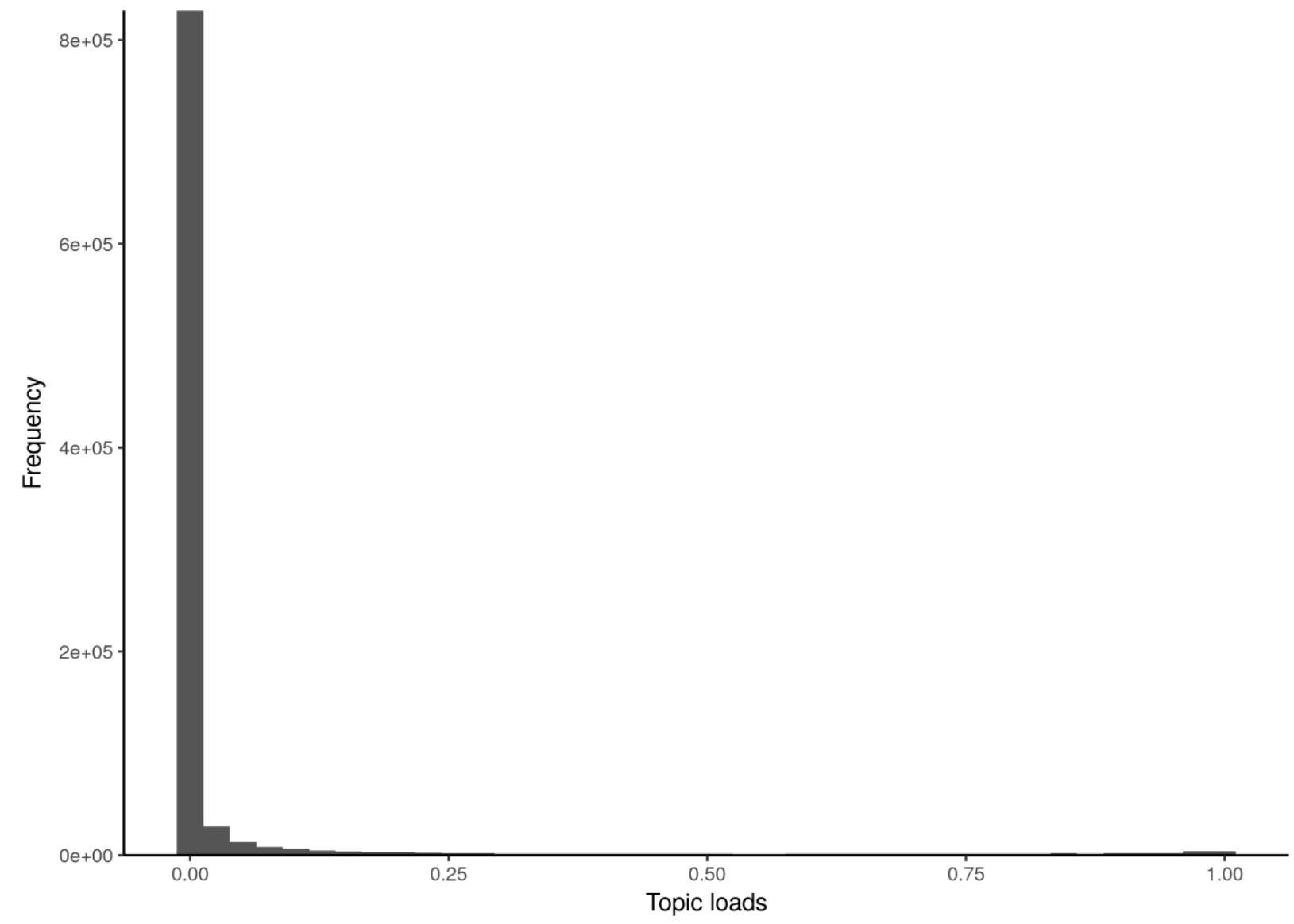

Figure A.22: Histogram of the document loads in topic "Court cases" 


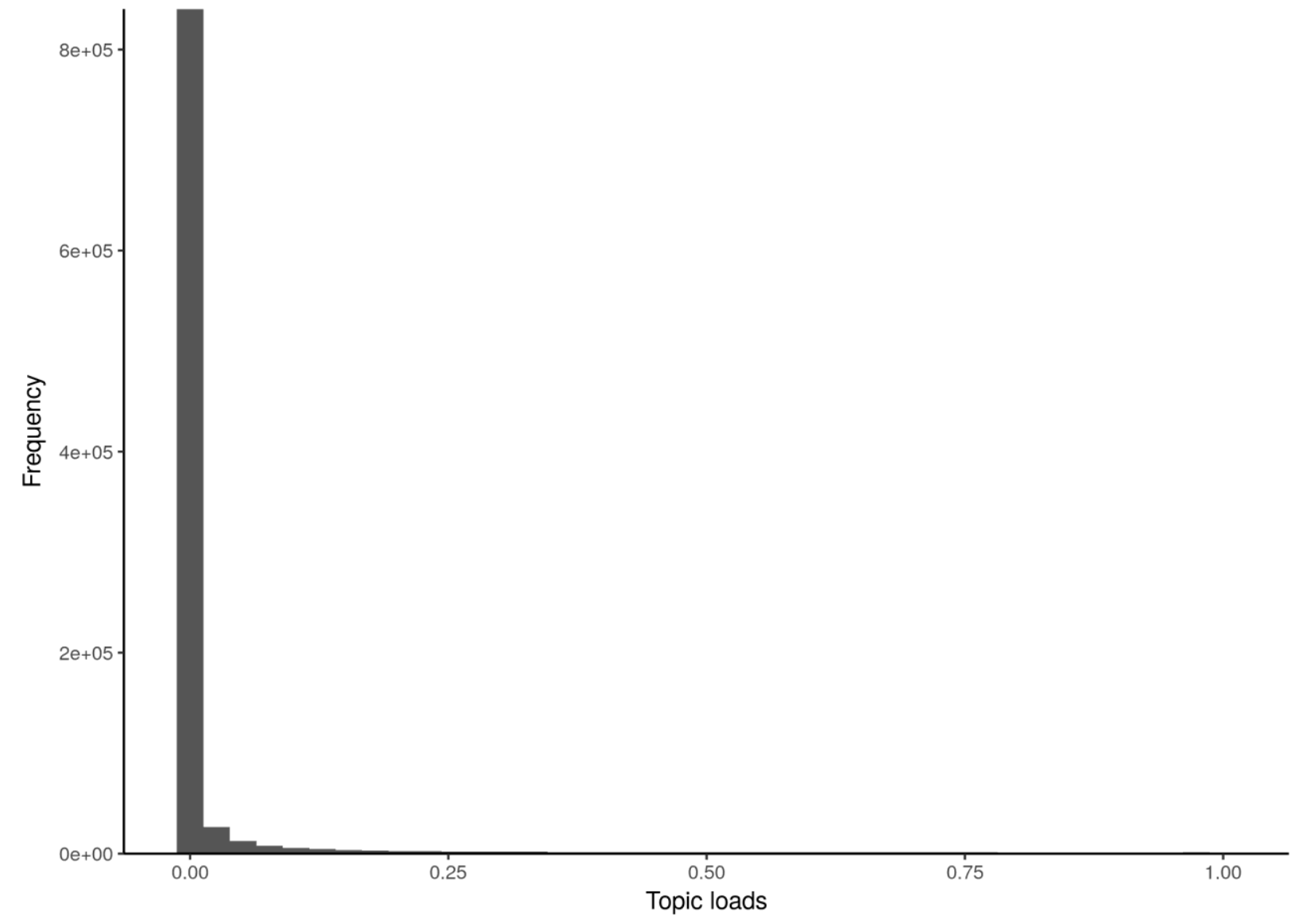

Figure A.23: Histogram of the document loads in topic "Cultural review" 


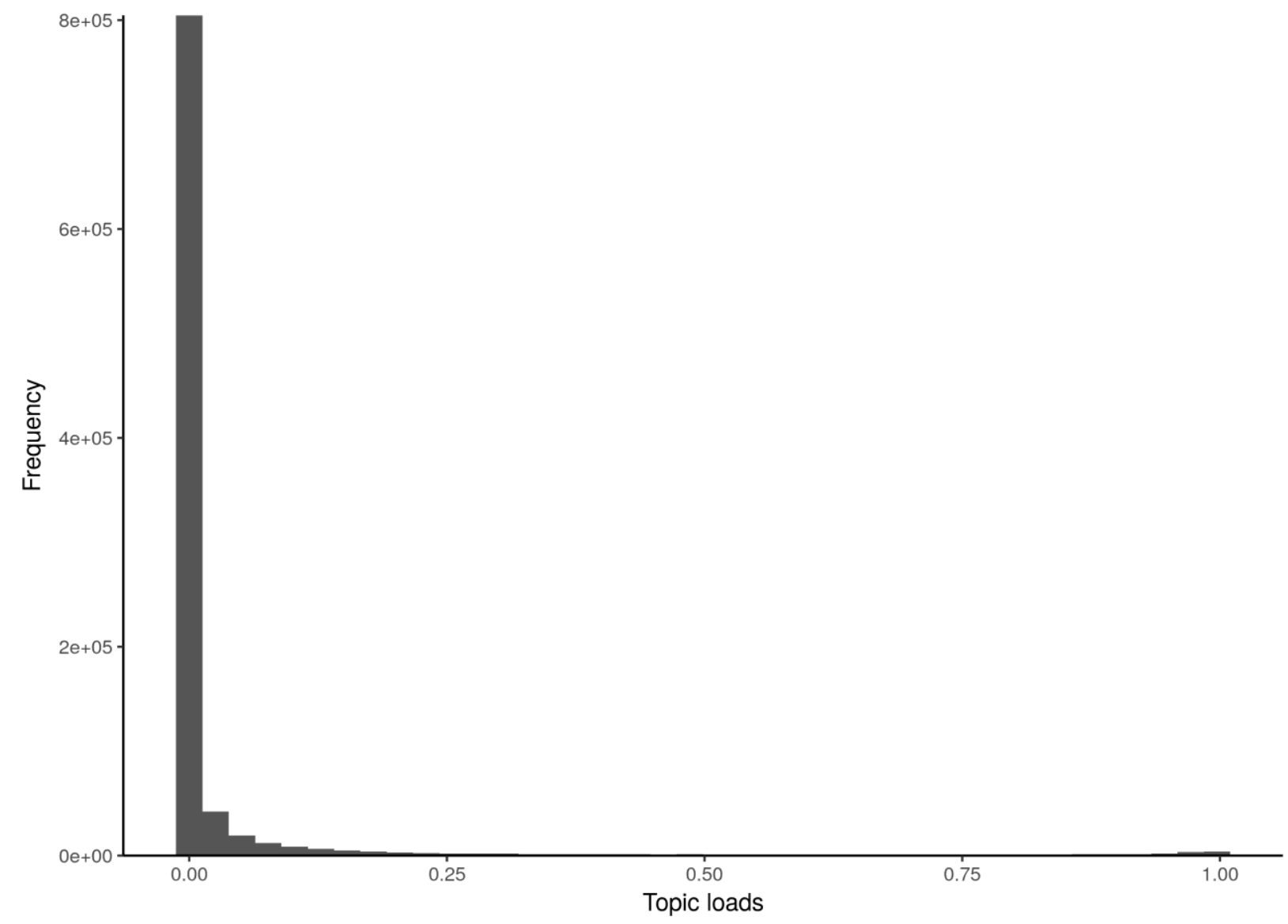

Figure A.24: Histogram of the document loads in topic "Economic analyses" 


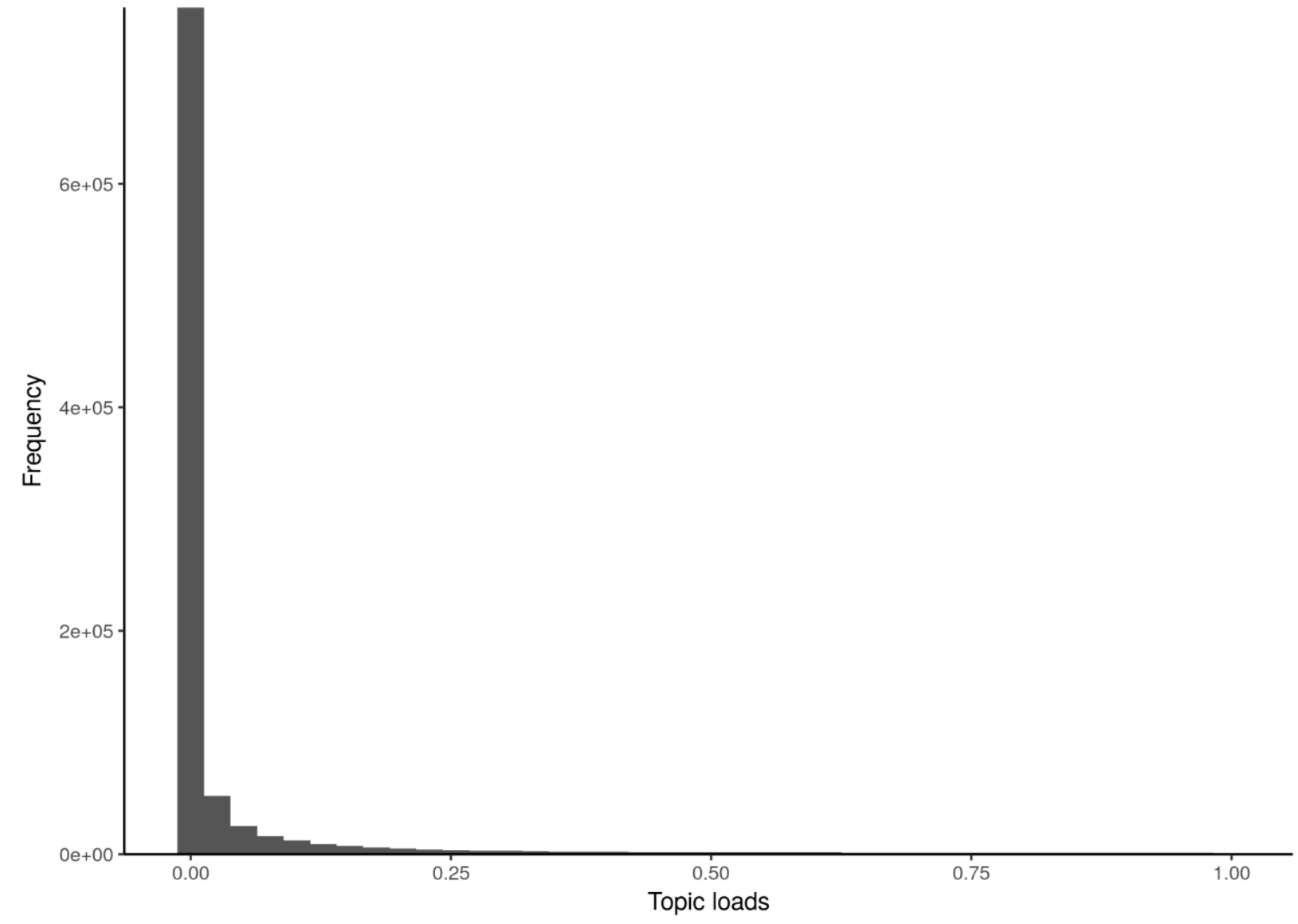

Figure A.25: Histogram of the document loads in topic "Education" 


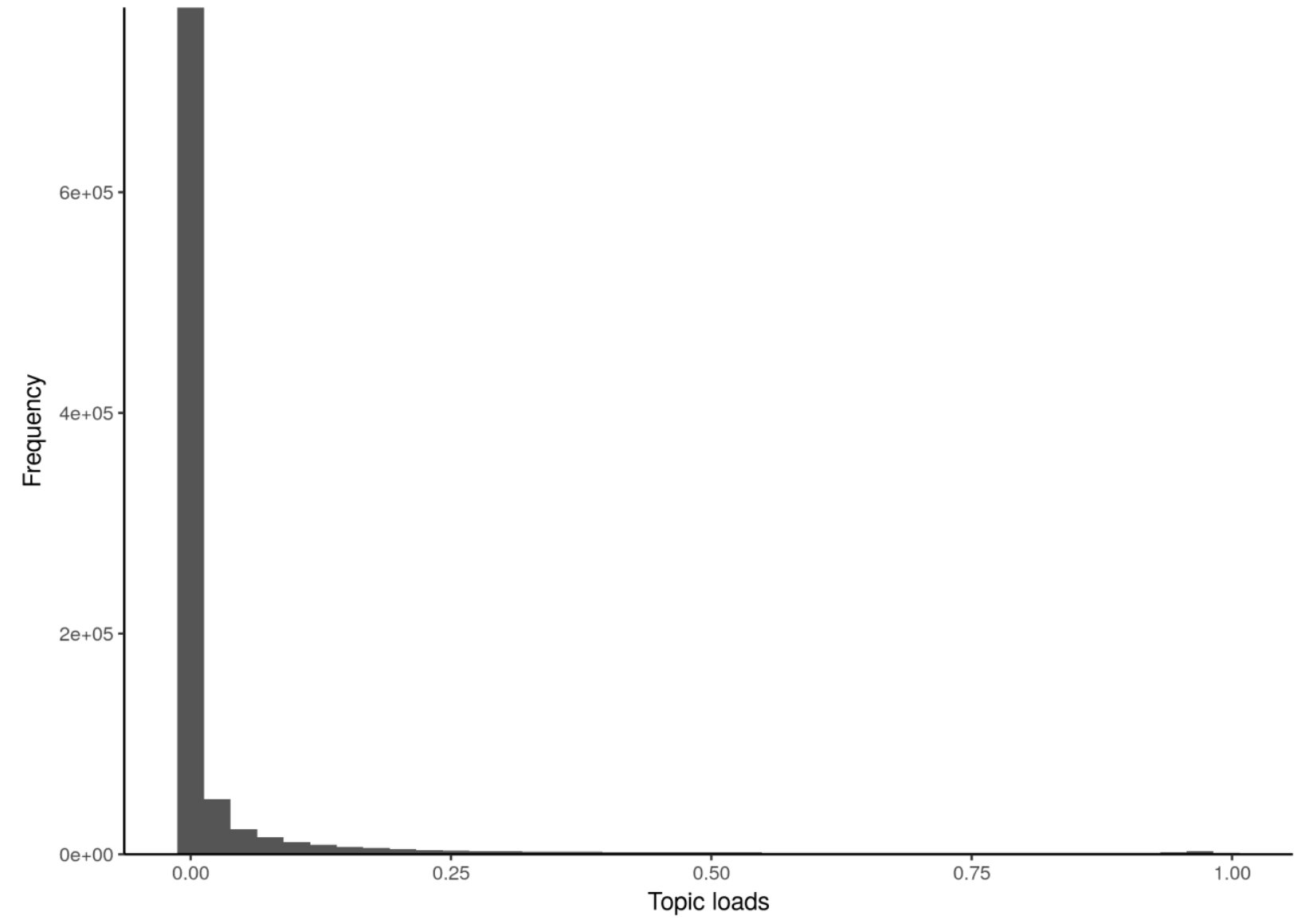

Figure A.26: Histogram of the document loads in topic "Emergencies" 


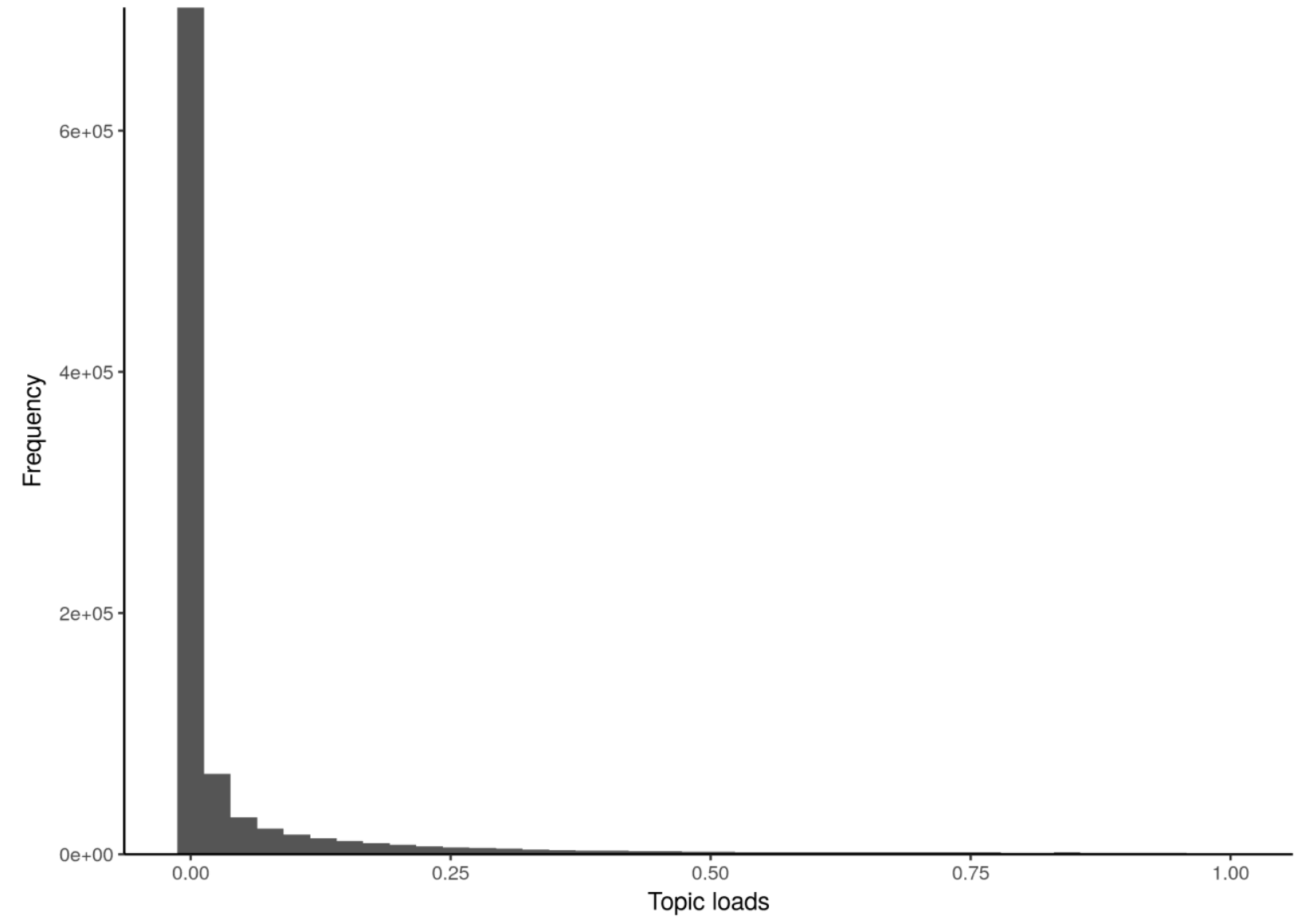

Figure A.27: Histogram of the document loads in topic "Energy policies" 


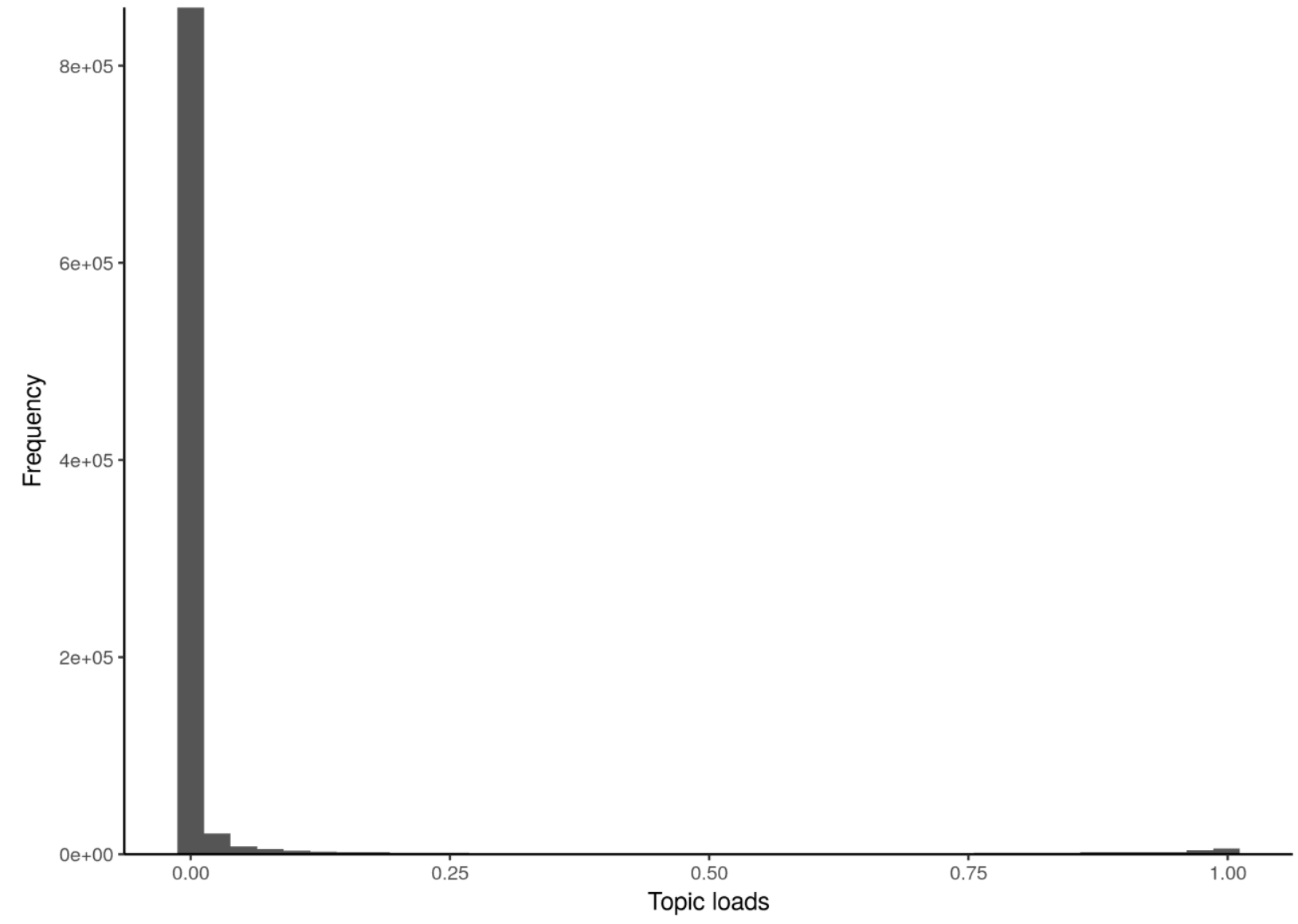

Figure A.28: Histogram of the document loads in topic "Football" 


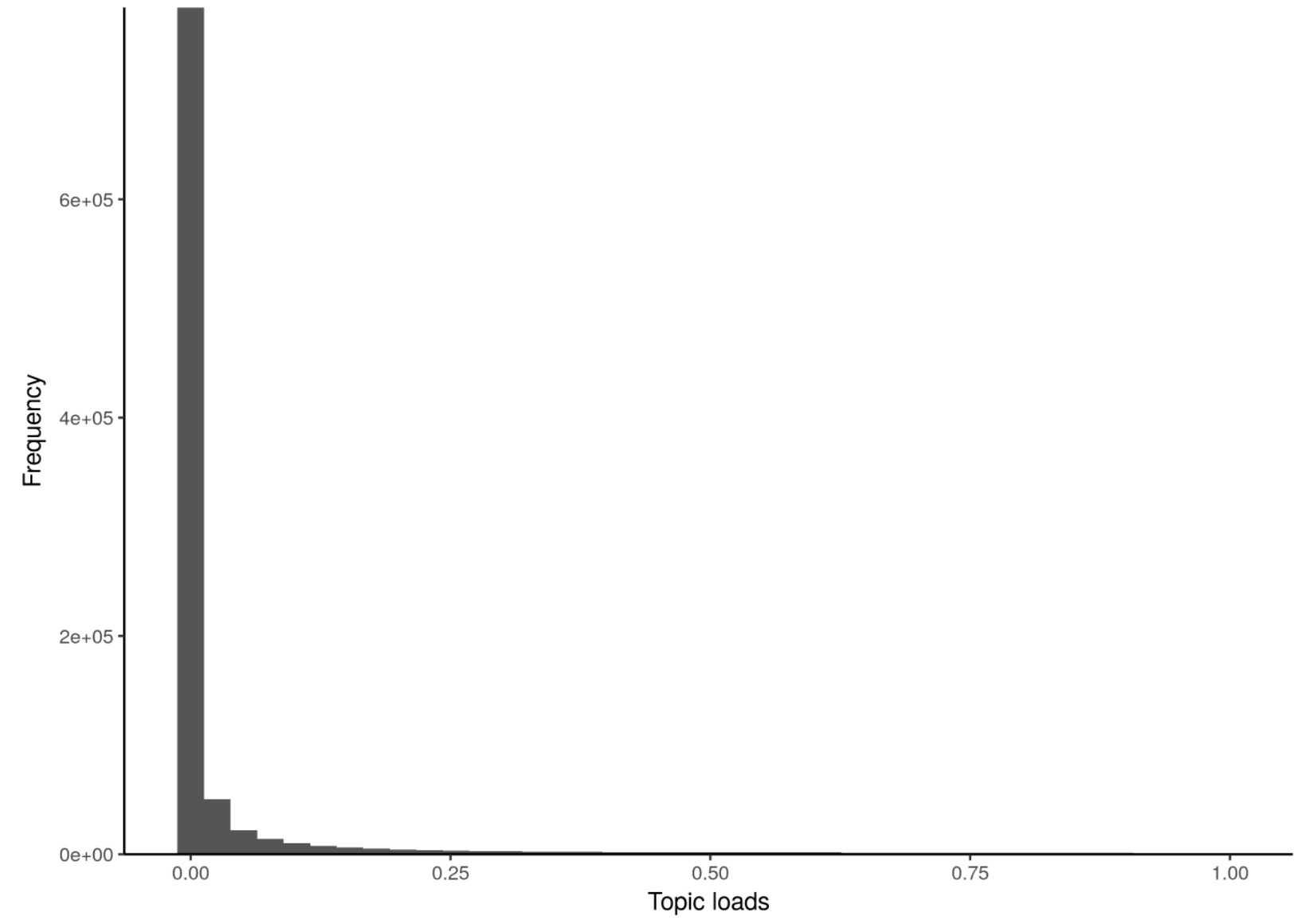

Figure A.29: Histogram of the document loads in topic "Health and technology" 


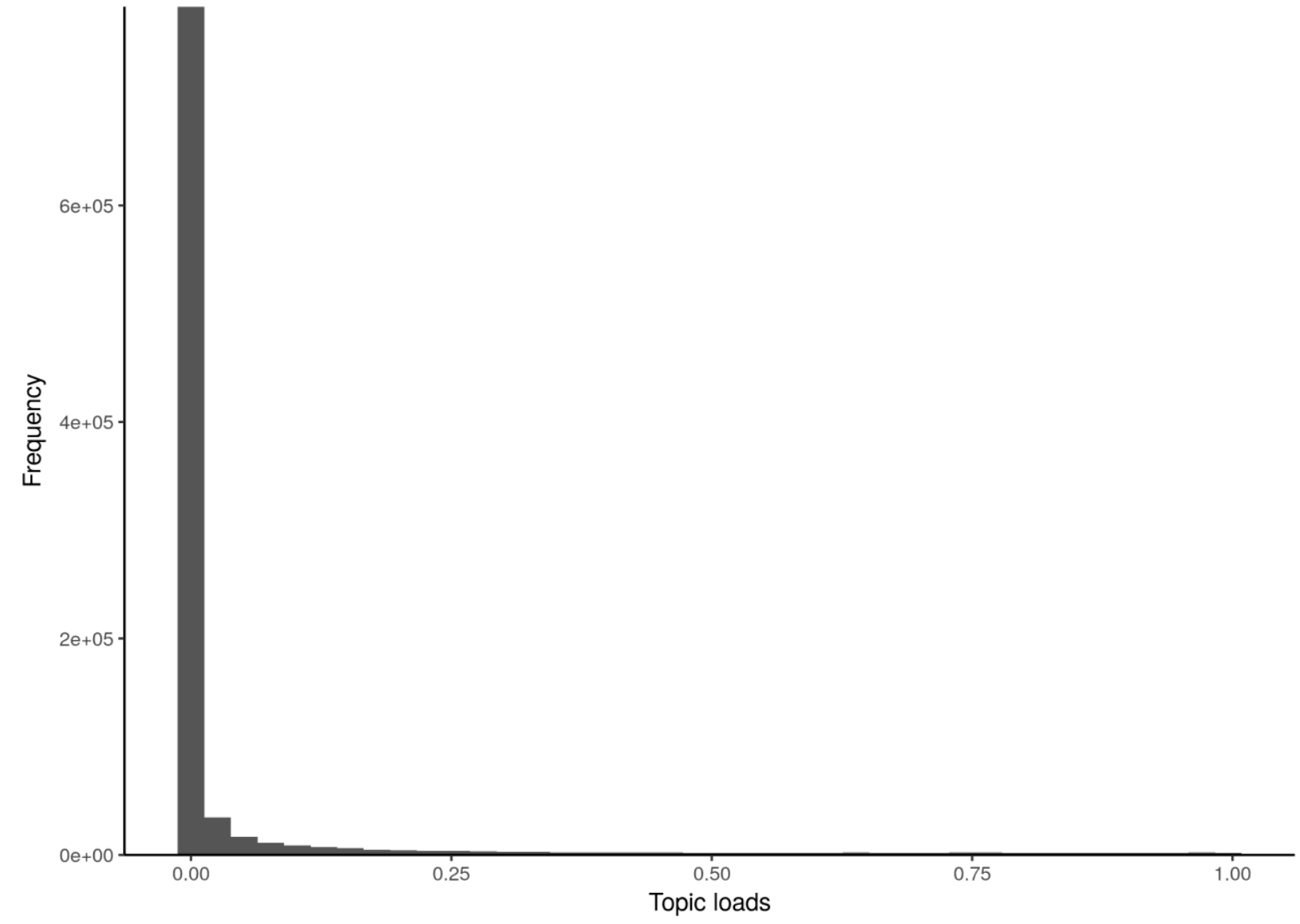

Figure A.30: Histogram of the document loads in topic "Immigration" 


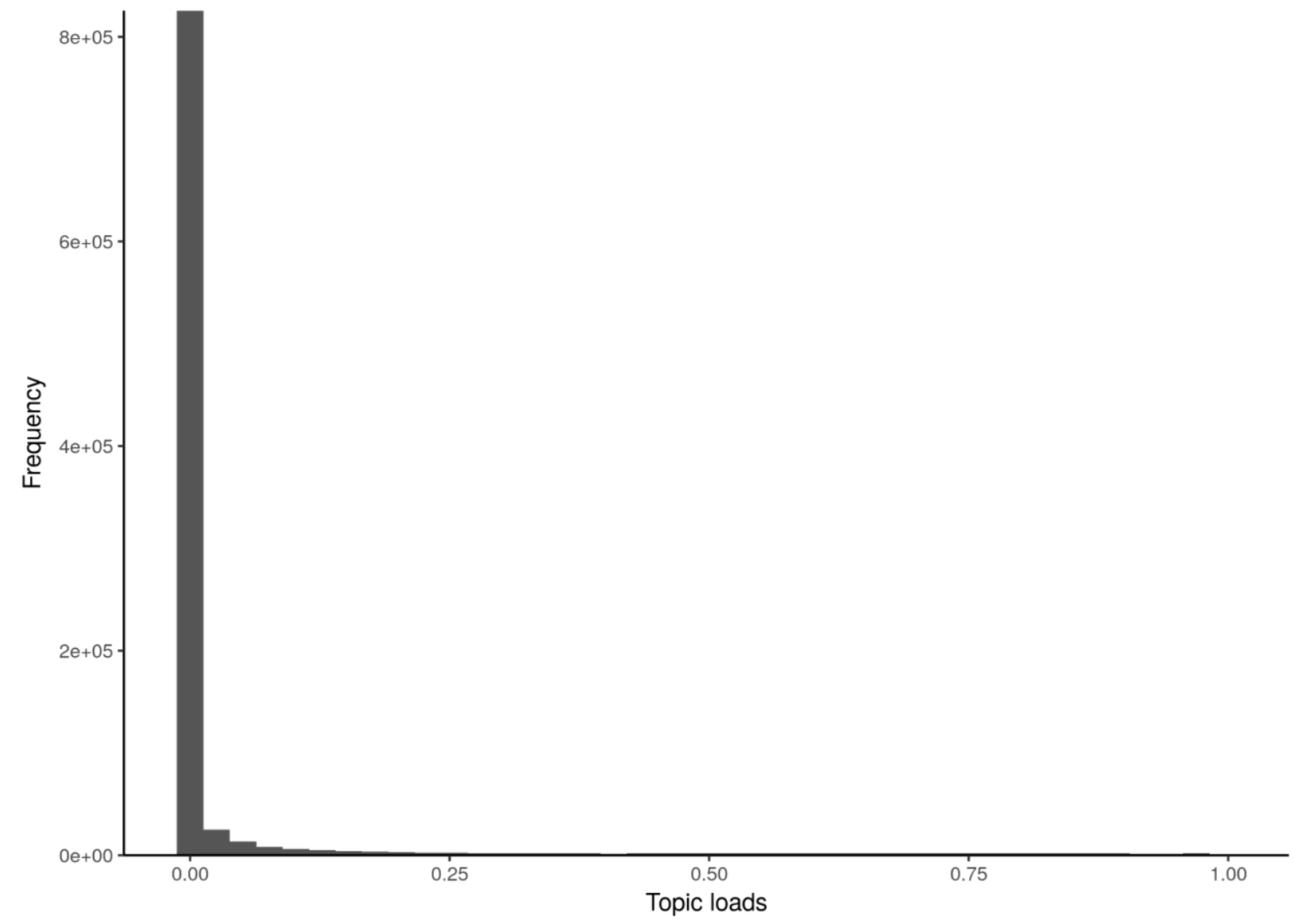

Figure A.31: Histogram of the document loads in topic "Infrastructure" 


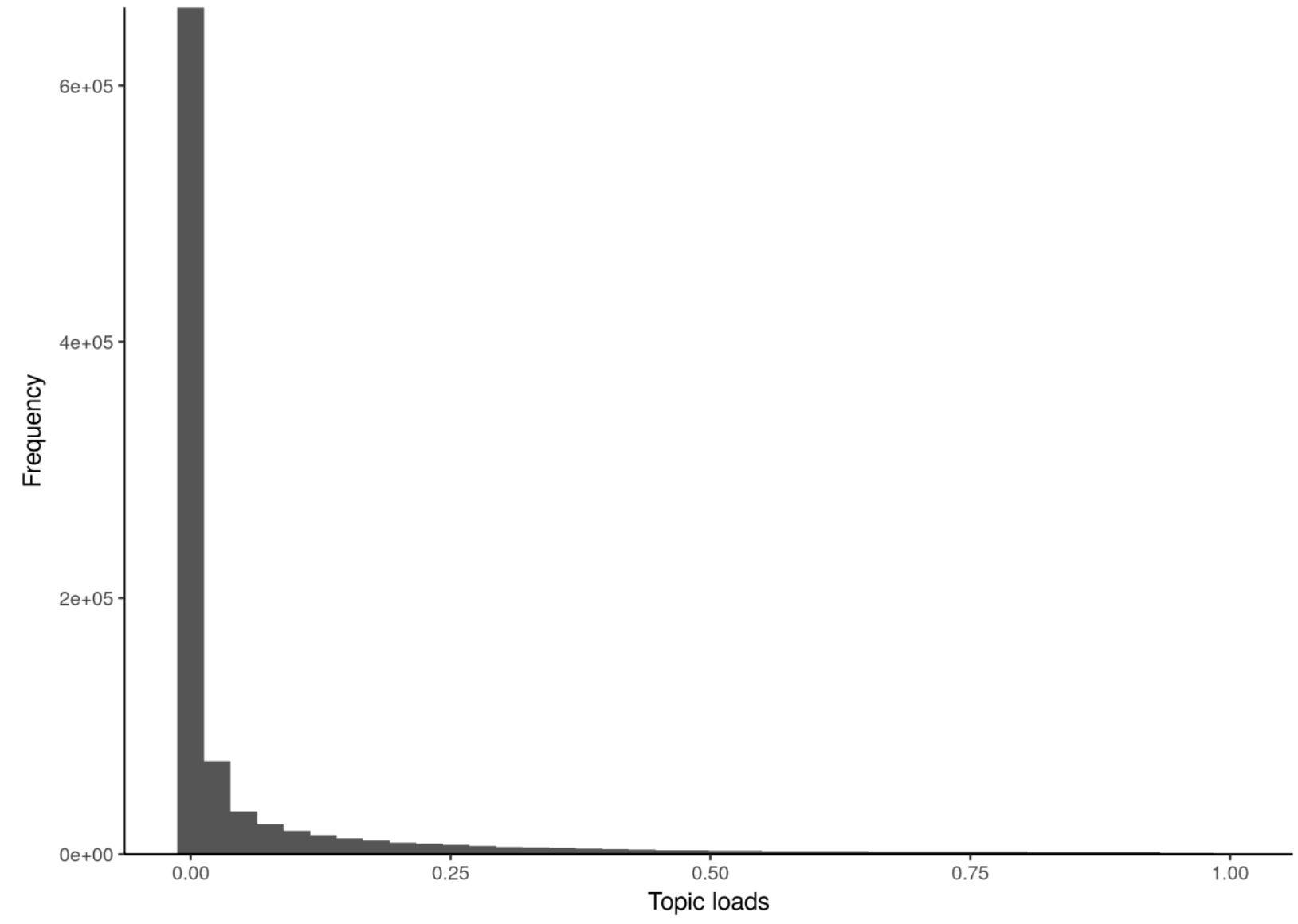

Figure A.32: Histogram of the document loads in topic "Intellectual" 


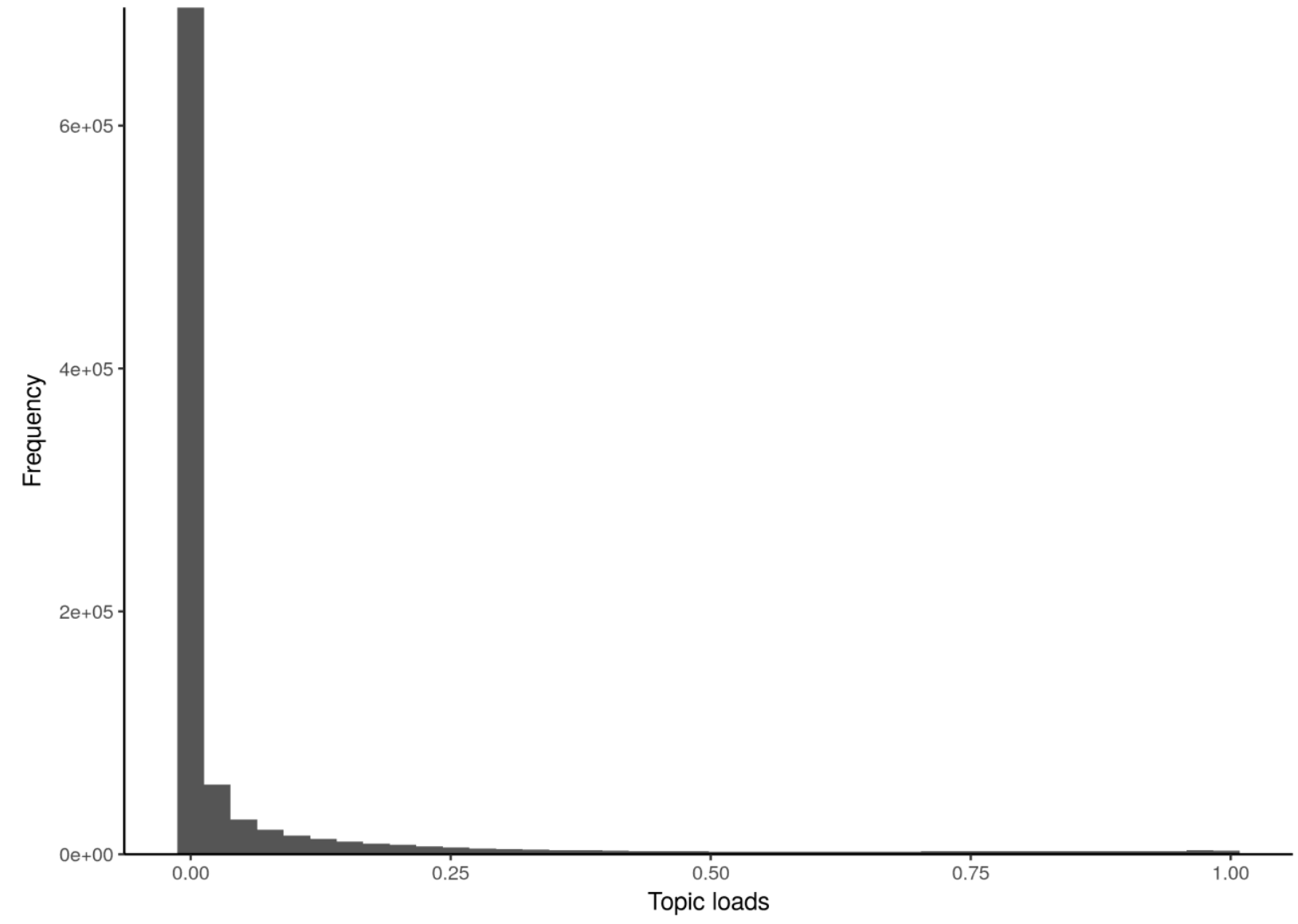

Figure A.33: Histogram of the document loads in topic "National politics" 


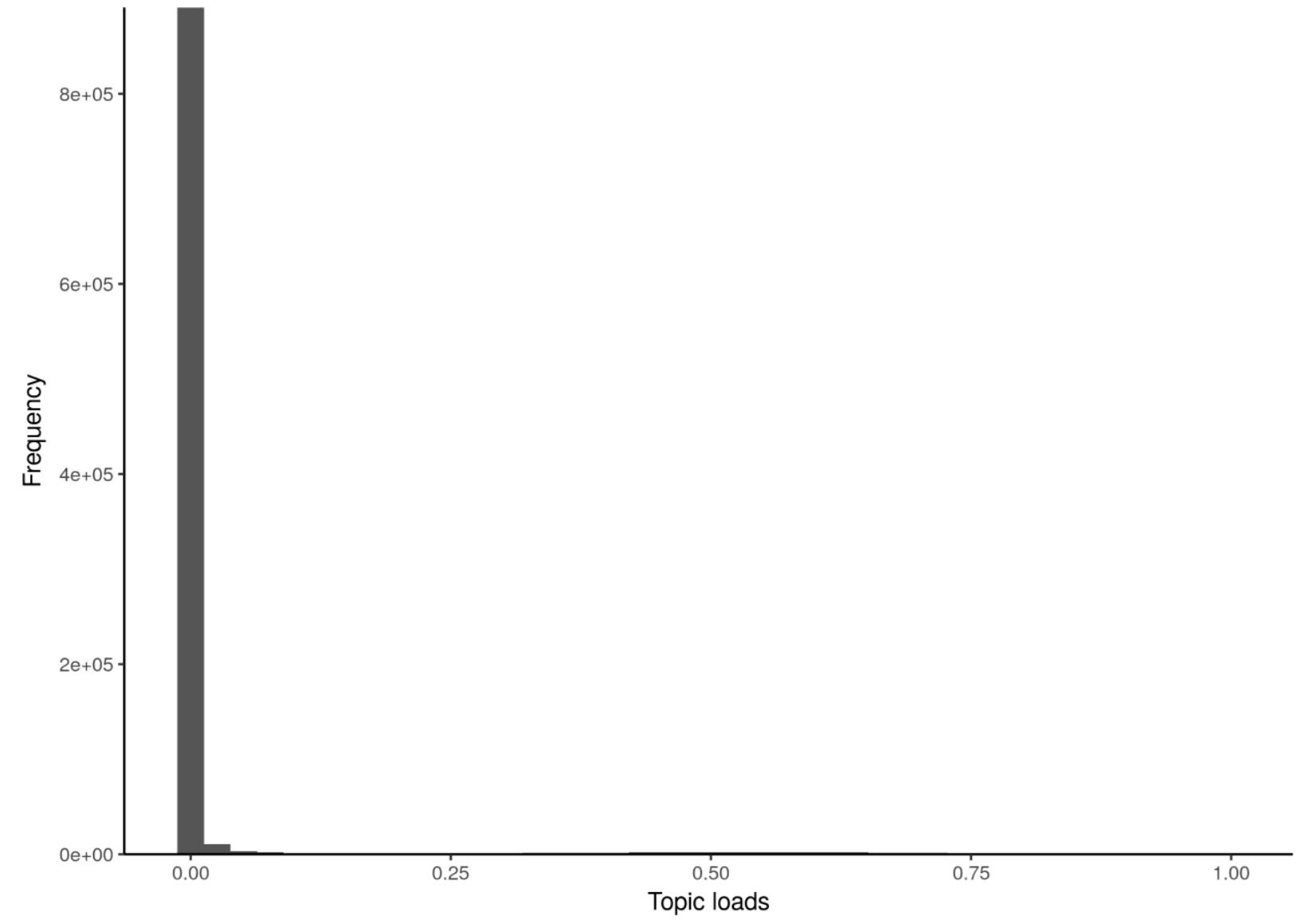

Figure A.34: Histogram of the document loads in topic "New Norwegian 


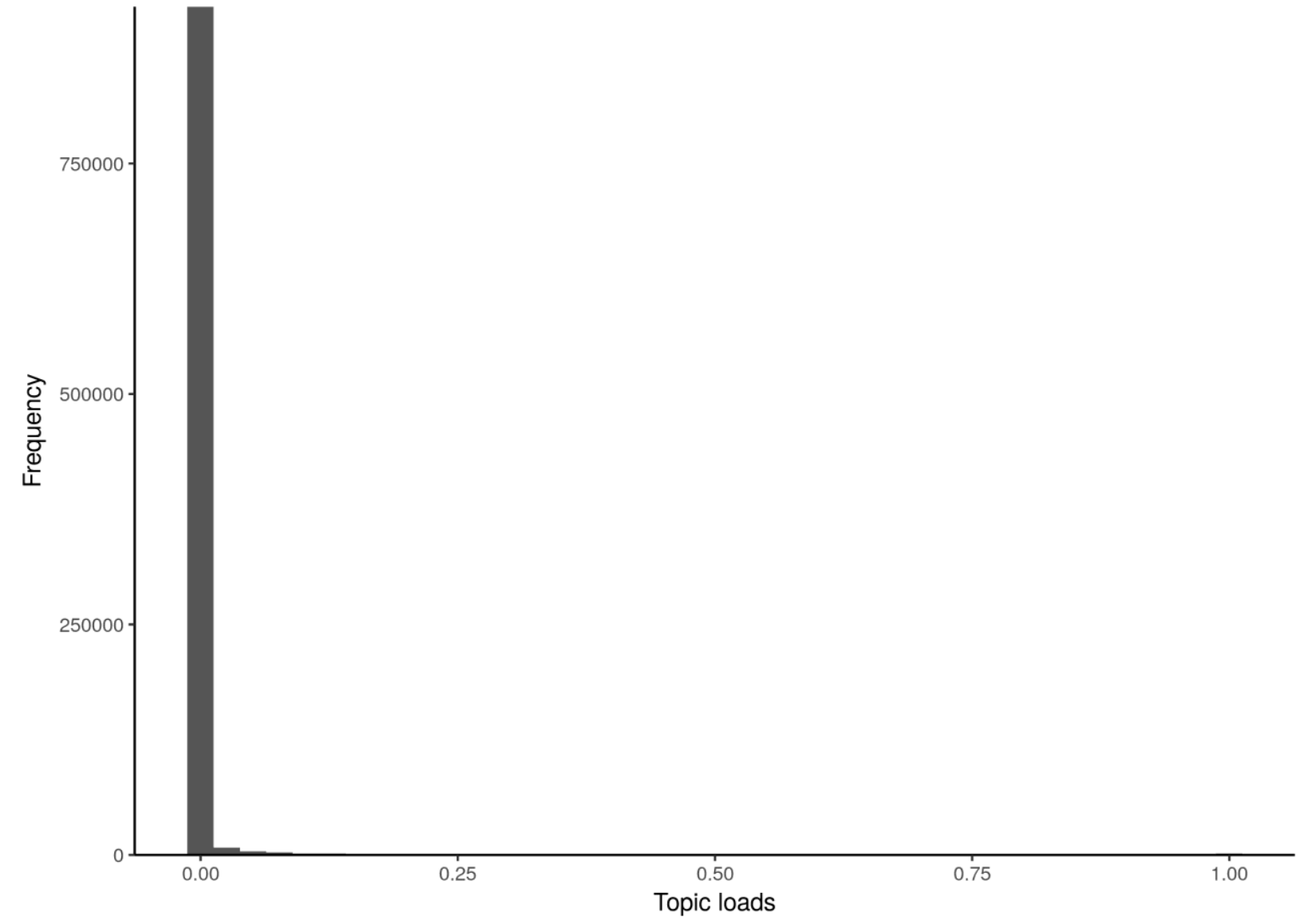

Figure A.35: Histogram of the document loads in the noise category "Ads" 


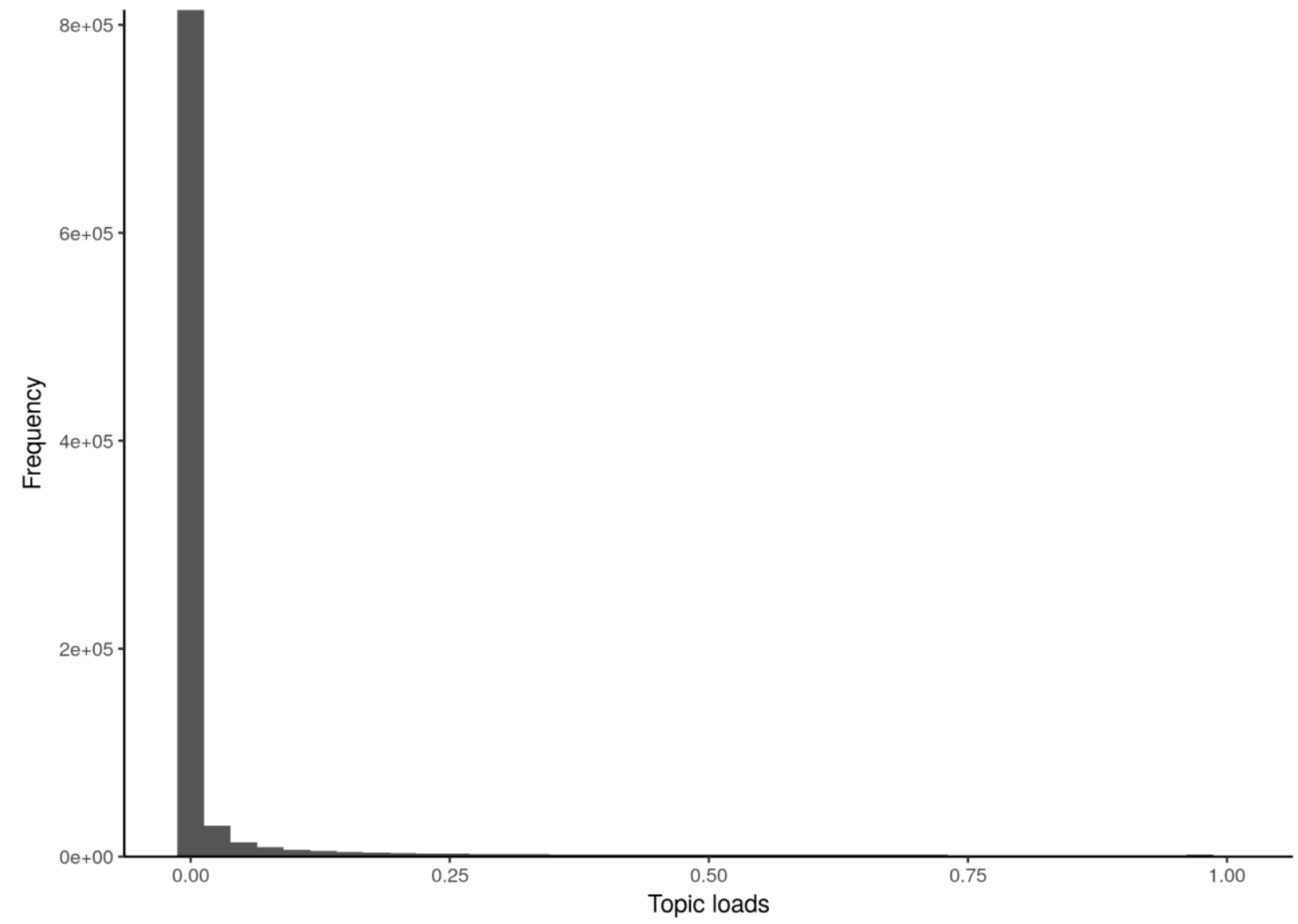

Figure A.36: Histogram of the document loads in the noise category "Cultural Events" 


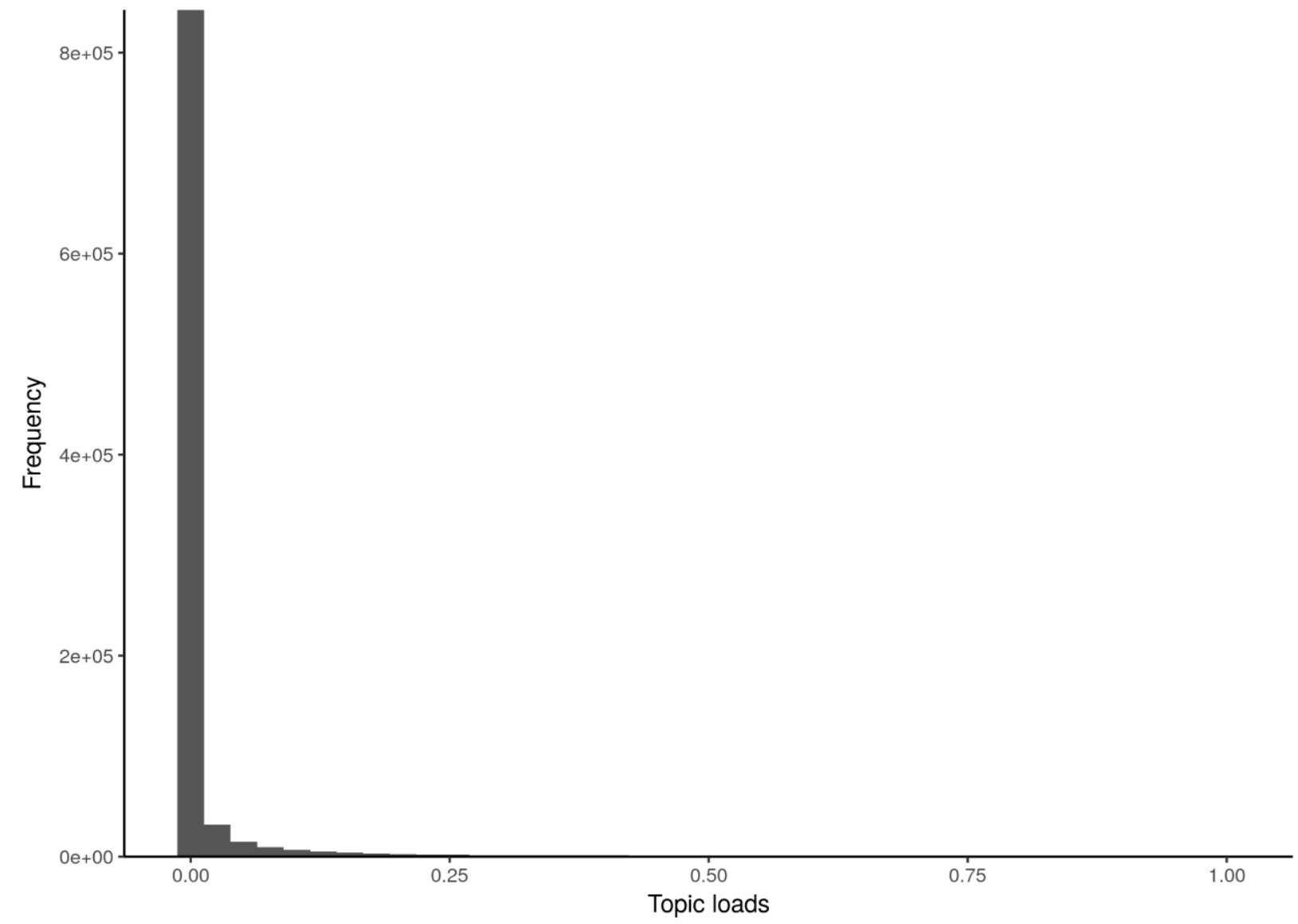

Figure A.37: Histogram of the document loads in the noise category "English" 


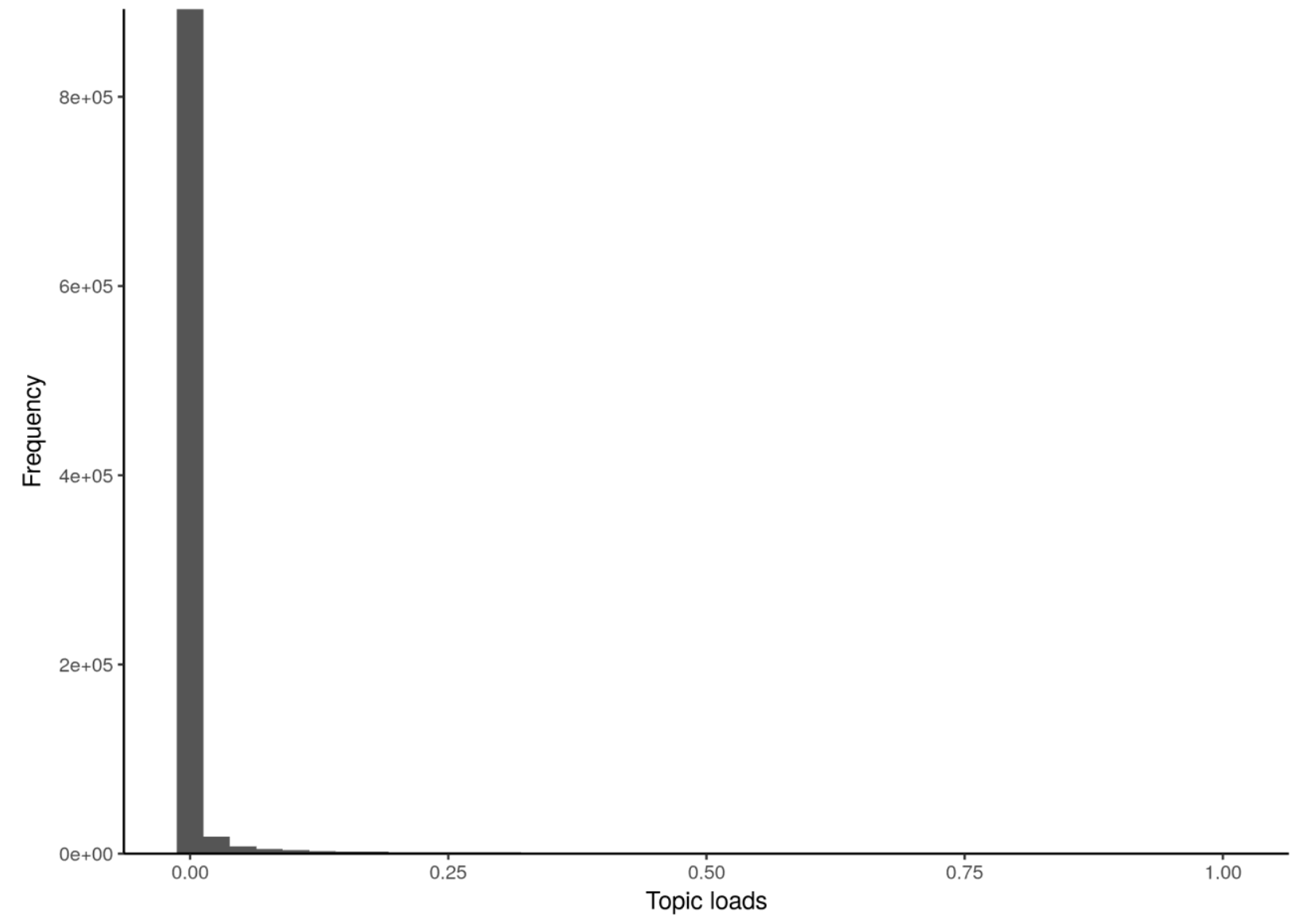

Figure A.38: Histogram of the document loads in the noise category "Events" 


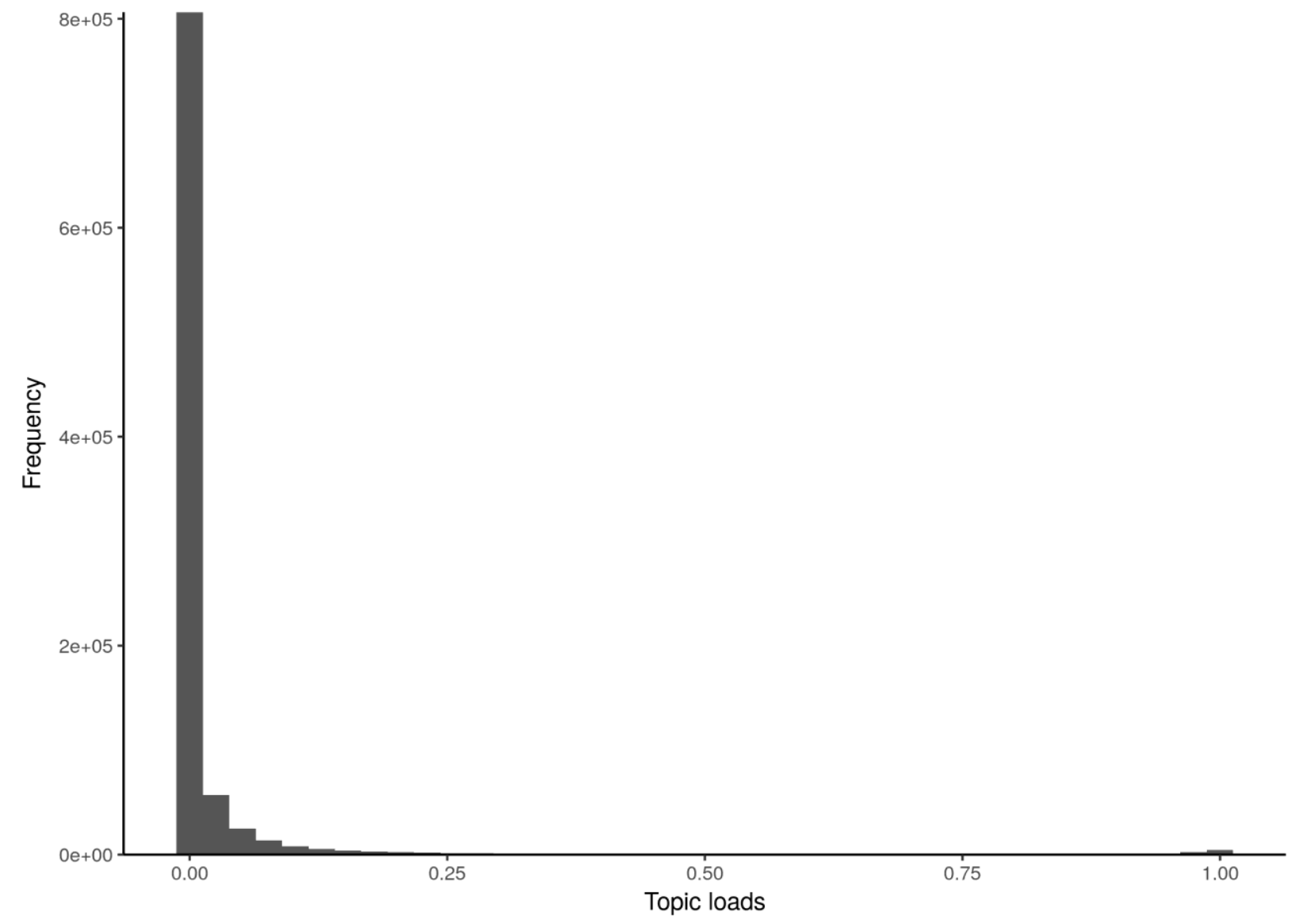

Figure A.39: Histogram of the document loads in the noise category "Property exchange" 


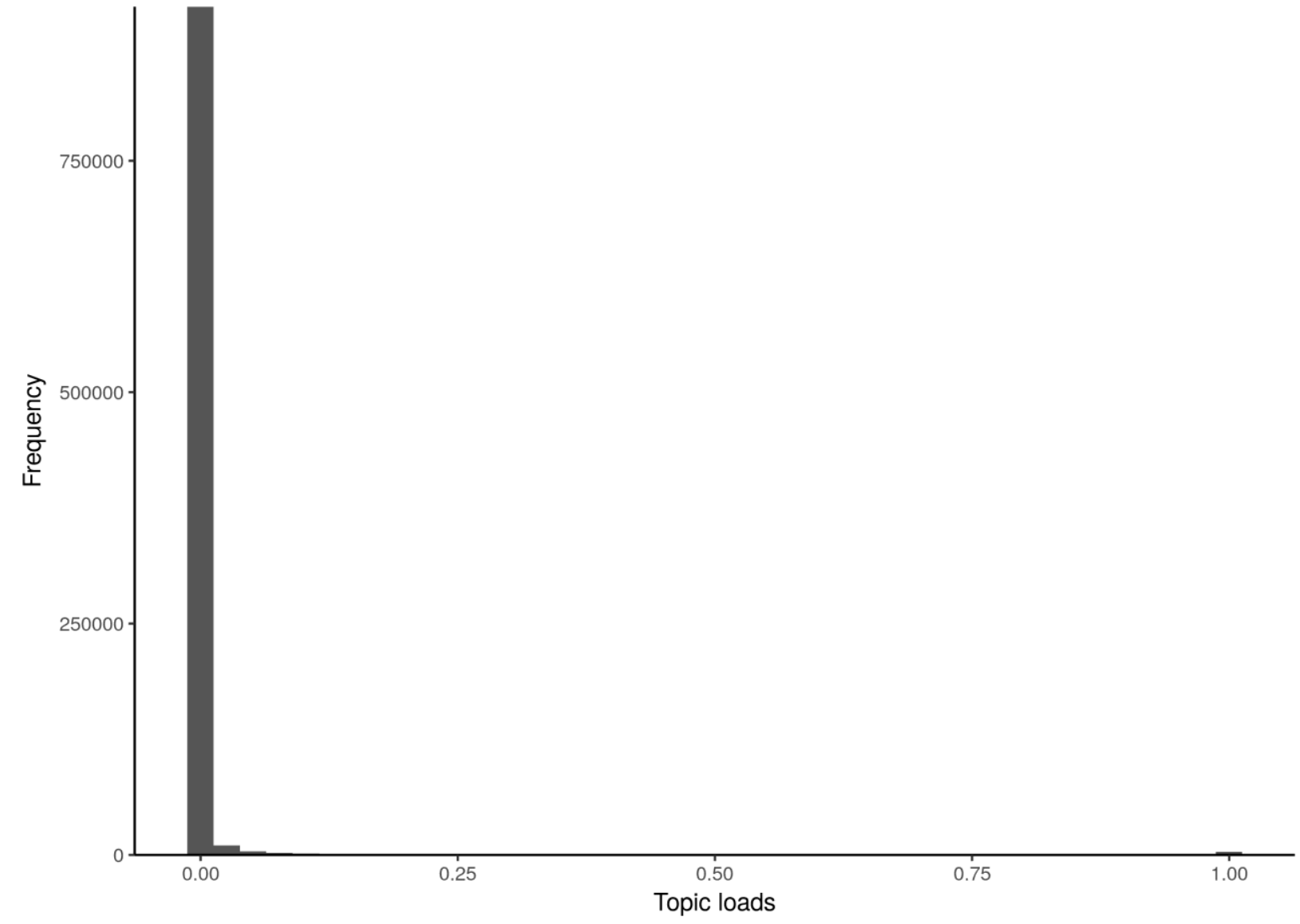

Figure A.40: Histogram of the document loads in the noise category "Sport results" 


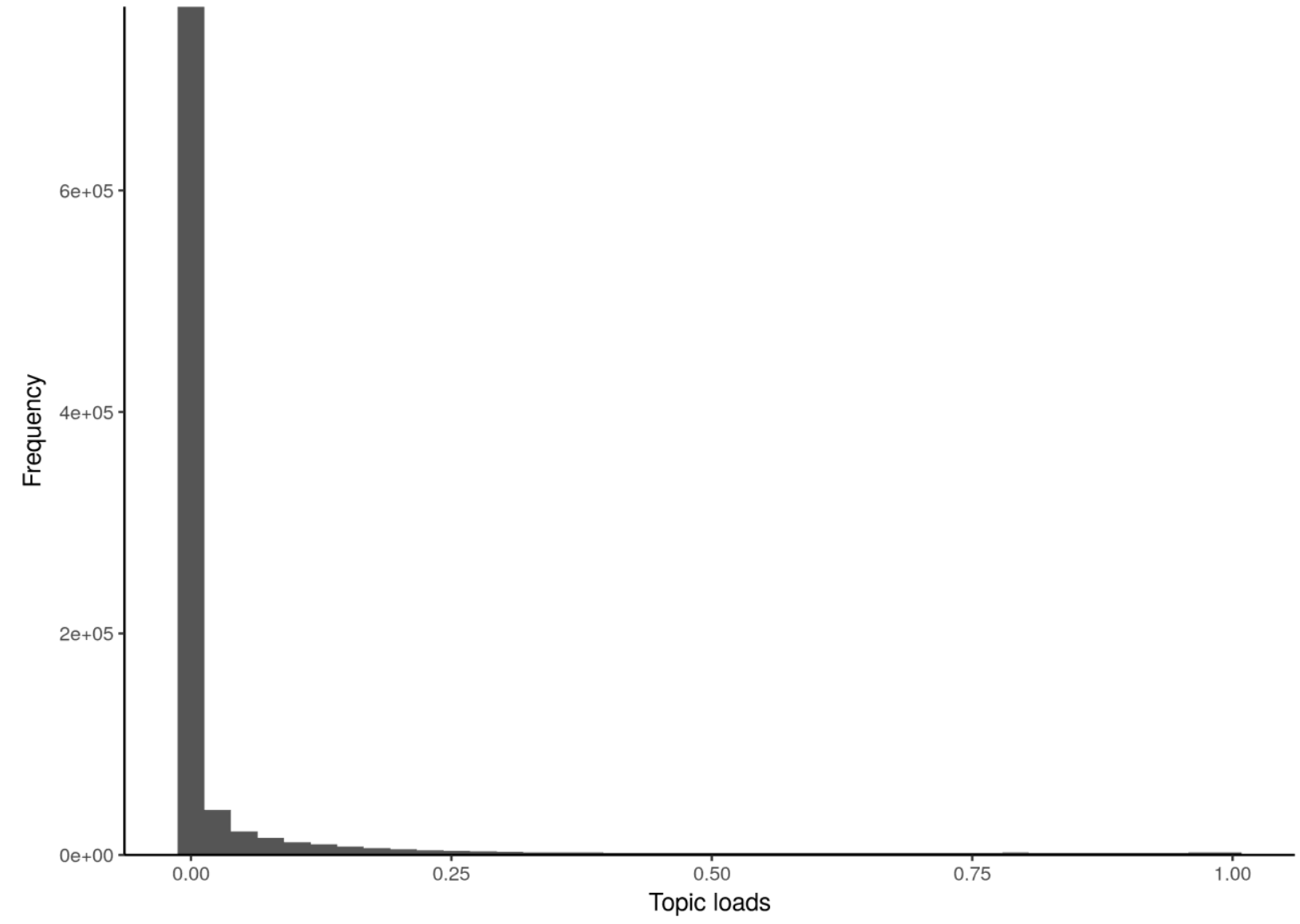

Figure A.41: Histogram of the document loads in topic "Portfolio negotiations" 


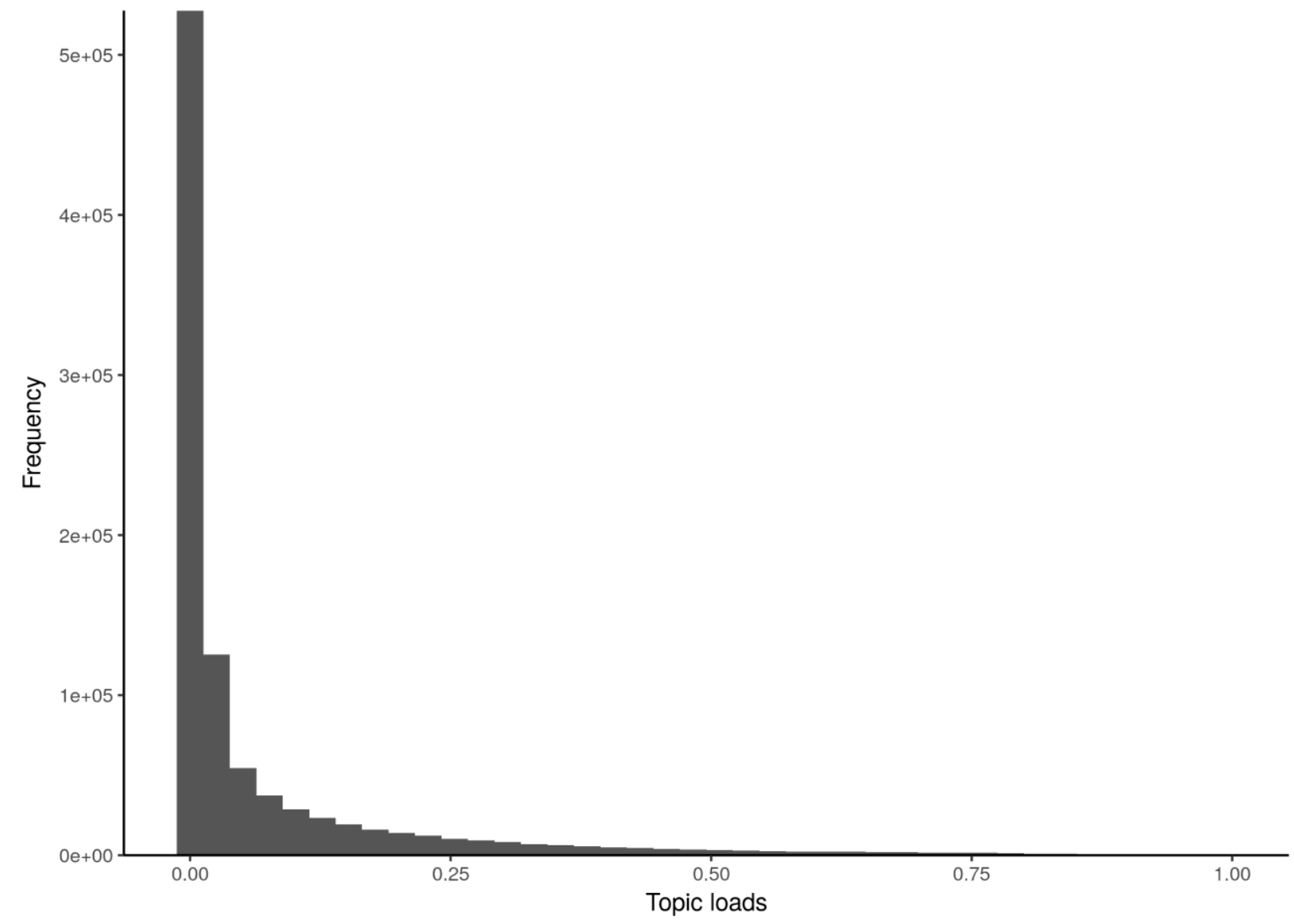

Figure A.42: Histogram of the document loads in topic "Profile features" 


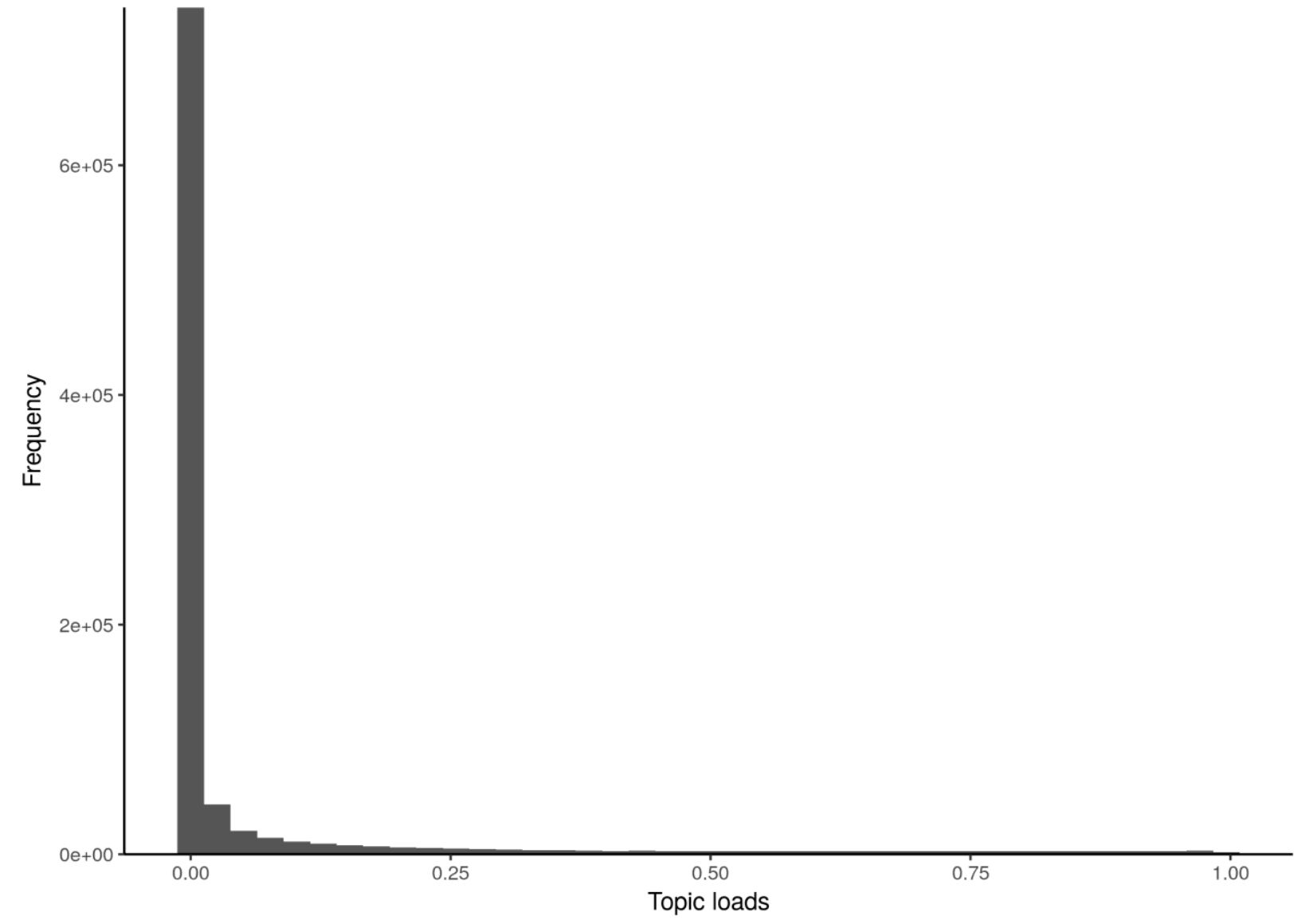

Figure A.43: Histogram of the document loads in topic "Urban planning" 


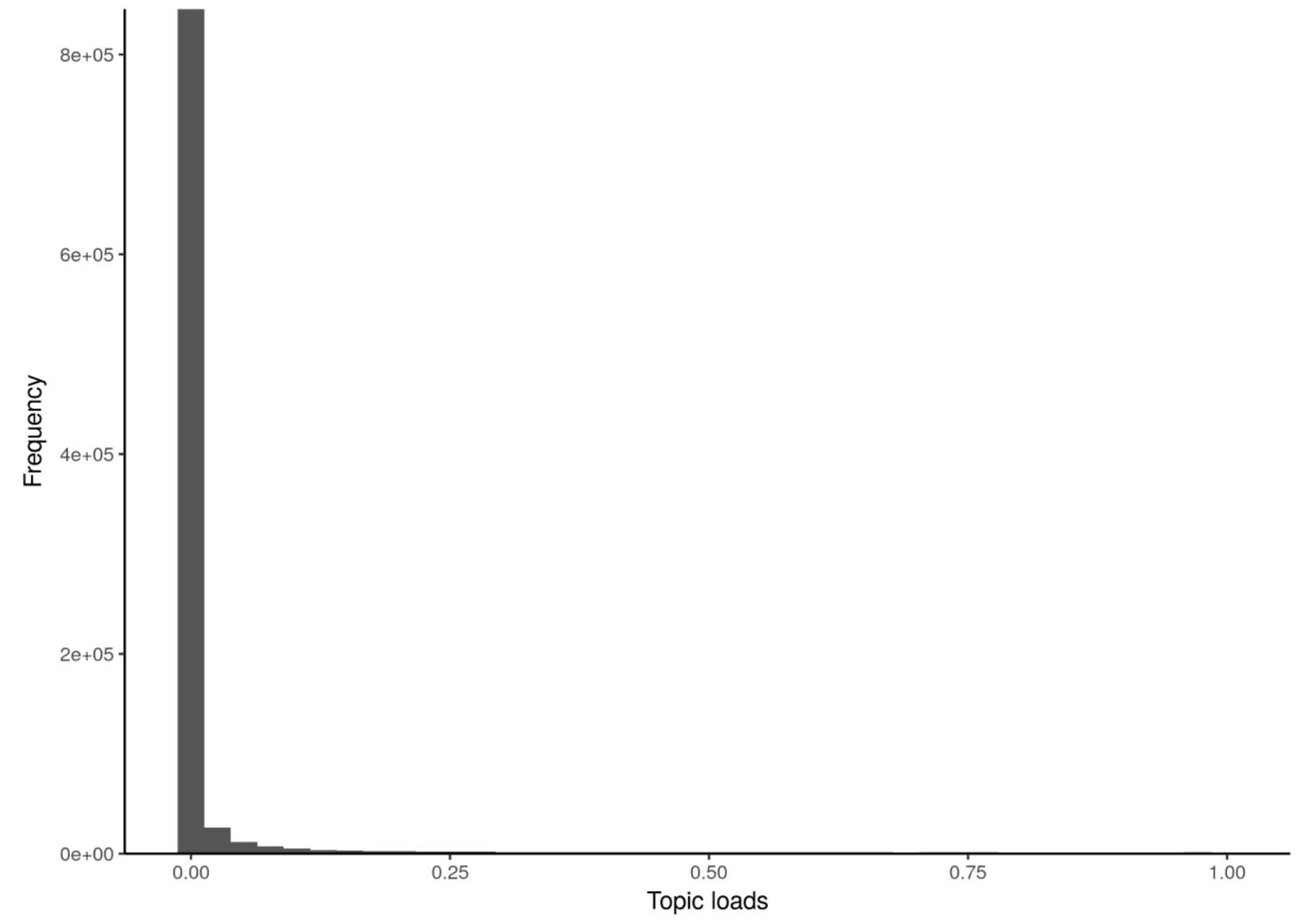

Figure A.44: Histogram of the document loads in topic "Urban-rural" 